TÁSSIA FARSSURA LIMA DA SILVA

O PROCESSO DE PROJETO NO SEGMENTO DE PROJETOS INDUSTRIAIS

São Paulo

2014 


\section{O PROCESSO DE PROJETO NO SEGMENTO DE PROJETOS INDUSTRIAIS}

Dissertação apresentada à Escola Politécnica da Universidade de São Paulo para obtenção do Título de Mestre em Ciências

Área de Concentração:

Engenharia de Construção Civil e Urbana

Orientador: Prof. Livre-Docente Silvio Burrattino Melhado 
Silva, Tássia Farssura Lima da O processo de projeto no segmento de projetos industriais / T.F.L. da Silva. -- São Paulo, 2014. $140 p$.

Dissertação (Mestrado) - Escola Politécnica da Universidade de São Paulo. Departamento de Engenharia de Construção Civil.

1.Construção civil 2.Processo (Projeto) 3.Projetos industriais I.Universidade de São Paulo. Escola Politécnica. Departamento de Engenharia de Construção Civil Il.t. 
Aos meus pais, exemplo de caráter e dedicação, e por tudo aquilo que me proporcionaram.

À minha avó pelo amor e dedicação ano após ano. 


\section{AGRADECIMENTOS}

Agradeço a Deus, causa primária de todas as coisas.

Ao meu orientador e amigo, Silvio Melhado pela sua dedicação, orientação, paciência, incentivo e acima de tudo por sua contribuição neste trabalho. Agradeço por acreditar em minha dedicação e potencial, além da oportunidade de aprendizado, crescimento acadêmico, profissional e pessoal.

Ao Prof. Dr. Francisco Cardoso pela oportunidade de realizar este trabalho acadêmico.

À Prof. Dra. Marly M. Carvalho pelos ensinamentos e contribuições tanto em sala de aula como no exame de qualificação.

Ao Prof. Dr. Sérgio Alfredo R. da Silva (in memoriam) pela participação, análises significativas e contribuições no exame de qualificação.

Ao Wagner Vieira, grande amigo e exemplo profissional, pelo incentivo, opiniões, troca de experiências e momentos de descontração.

Aos gerentes de projetos, gerentes de departamentos, planejadores, engenheiros e projetistas das empresas que permitiram a realização dos estudos de caso e a integração entre o mundo acadêmico e profissional.

Aos funcionários do Departamento de Engenharia de Construção Civil pelo prestimoso auxílio e apoio às atividades do programa de pós-graduação.

Meus agradecimentos a todos que colaboraram e me apoiaram, direta ou indiretamente, na elaboração deste trabalho. 


\title{
O PROCESSO DE PROJETO NO SEGMENTO DE PROJETOS INDUSTRIAIS
}

\author{
RESUMO
}

A crescente demanda por rapidez na construção, menores custos e maior controle da qualidade geram uma complexidade na gestão do processo de projeto. Estudos voltados aos projetos industriais ainda são em minoria, ou seja, há poucos trabalhos desenvolvidos e publicados com este tema. Além disso, especificamente no segmento escolhido, a complexidade e a diversidade dos projetos industriais, associadas às inúmeras exigências de mercado demandam melhorias na gestão de projetos.

O trabalho tem como objetivo, por meio de estudos de caso, descrever o processo de projeto e analisar as práticas de gestão utilizadas em projetos industriais, assim como discutir a atuação dos coordenadores de projeto e suas dificuldades. Como resultado, será possível propor diretrizes aos agentes envolvidos, visando à melhoria contínua e a potencializar o sucesso dos projetos industriais.

Para que se atinjam os resultados desejados na fase de projeto, as informações fornecidas aos projetistas precisam ser completas e confiáveis. Para isso, o comprometimento do cliente desde o início é fundamental, criando-se a colaboração necessária para se alcançarem os objetivos do empreendimento. Dificuldades e falhas da coordenação de projetos, comuns aos casos analisados, significaram prejuízos quanto a prazos, custos e qualidade, que, somando-se à falta de comprometimento do cliente com a colaboração no processo, podem comprometer o sucesso dos projetos industriais.

Palavras-chave: Construção Civil. Processo de Projeto. Gestão. Projetos Industriais. 


\title{
THE DESIGN PROCESS OF INDUSTRIAL PROJECTS
}

\begin{abstract}
The diversity of the industrial projects and market requirements increasingly demand design process improvement. Concerning the industrial projects, a field in which there are quite few research work published, the rising demand for speed in construction, lower costs and quality assurance generate complexity in managing the design process.

Through a group of case studies, this Master Thesis aims to describe the design process and analyse the design management practices performed in industrial projects, as well as to discuss the design managers activities and difficulties. The results will be evaluated in order to propose guidelines to possible management improvements to raise the probability of project success.

For the design phase to be performed with the desired level of success, the information provided to designers needs to be complete and reliable. For this, client engagement from the early beginning is crucial, creating a collaborative action in order to achieve the project goals. As it was observed in the case studies, the management practices performed in industrial projects have shown several difficulties and failures, an issue that, adding to the client's lack of commitment with regard to collaboration in the process, may hinder the success of industrial projects.
\end{abstract}

Keywords: Civil construction. Design process. Management. Industrial Projects. 


\section{LISTA DE FIGURAS}

Figura 1 - Condução do Estudo de Caso (Miguel, 2007)......................................................14

Figura 2 - Ligações entre os grupos de processos numa fase de projeto (PMBok, 2004)........19

Figura 3 - Integração de Grupos de Processos em um Projeto (PMBok, 2004)......................20

Figura 4 - $\mathrm{O}$ avanço do empreendimento em relação à chance de reduzir o custo de falhas do edifício (Hammarlund \& Josephson, 1992 apud Melhado, 1994)..........................................21

Figura 5 - Entendimento da relação entre "project management" e "design menagement" no

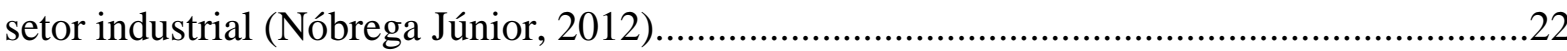

Figura 6 - Espectro da Incerteza (Adaptado de Wideman, 1992)........................................25

Figura 7 - Etapas da Gestão de Riscos (PMBok, 2008)......................................................27

Figura 8 - Modelo de etapas do processo de projeto (Melhado, 1994)...................................32

Figura 9 - Proposta de estruturação para a equipe multidisciplinar envolvida no

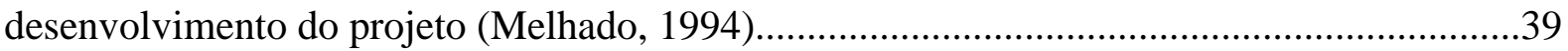

Figura 10 - A constituição da equipe do empreendimento (Grilo, 2002)................................40

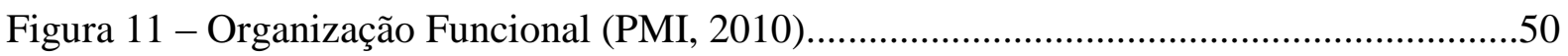

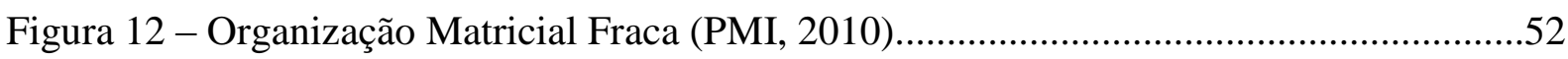

Figura 13 - Organização Matricial Forte (PMI, 2010).........................................................53

Figura 14 - Organização Matricial Balanceada (PMI, 2010)...............................................53

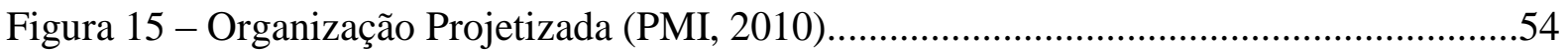

Figura 16 - Tarefas do processo de gestão da informação (McGee e Prusak, 1994)..............56

Figura 17 - Avaliação, verificação e controle do processo de projeto (Melhado et. al, 2005)

Figura 18 - Organograma da Empresa (Site da empresa)...................................................68

Figura 19 - Organograma da Empresa (Site da empresa).................................................69

Figura 20 - Sistemas e Recursos utilizados pela empresa (Site da empresa).........................70

Figura 21 - Planta geral do projeto - Estudo de Caso 1 (Dados de pesquisa)...........................73

Figura 22 - Organograma do Estudo de Caso 1 - Empresa A (Dados de pesquisa)................74

Figura 23 - Trincas - Estudo de Caso 1 (Dados de pesquisa)...................................................80

Figura 24 - Trincas - Estudo de Caso 1 (Dados de pesquisa)................................................80

Figura 25 - Escorregamento dos Platôs - Estudo de Caso 1 (Dados de pesquisa)....................81

Figura 26 - Escorregamento dos Platôs - Estudo de Caso 1 (Dados de pesquisa)....................81

Figura 27 - Planta geral do projeto - Estudo de Caso 2 (Dados de pesquisa).........................83

Figura 28 - Organograma - Fase Projeto - Estudo de Caso 2 (Dados de pesquisa).................86 
Figura 29 - Organograma - Fase Obra - Estudo de Caso 2 (Dados de pesquisa)......

Figura 30 - Problemas detectados na confecção de escadas com dois patamares - Estudo de

Caso 2 (Dados de pesquisa)

Figura 31 - Problemas detectados na confecção de escadas com dois patamares - Estudo de

Caso 2 (Dados de pesquisa). .93

Figura 32 - Problemas de compatibilidade (Dados de Pesquisa)........................................94

Figura 33 - Execução da obra - Estudo de Caso 2 (Dados de Pesquisa)...............................95

Figura 34 - Execução da obra - Estudo de Caso 2 (Dados de Pesquisa)...............................95

Figura 35 - Execução da obra - Estudo de Caso 2 (Dados de Pesquisa)...............................96

Figura 36 - Incidente com tubulação de incêndio - Estudo de Caso 2 (Dados de

Pesquisa)

Figura 37 - Incidente com um duto de ar condicionado - Estudo de Caso 2 (Dados de

Pesquisa)

Figura 38 - Desenho de referência fornecido pelo cliente - Estudo de Caso 2 2.....................98

Figura 39 - Planta geral do empreendimento UHR - Estudo de Caso 3................................100

Figura 40 - Organograma do Estudo de Caso - Estudo de Caso 3........................................104

Figura 41 - Organograma geral - Estudo de Caso 3 .............................................................107

Figura 42 - Organograma da produção - Estudo de Caso 3 ….............................................108

Figura 43 - Organograma da equipe de planejamento - Estudo de Caso 3.........................108

Figura 44 - Organograma da equipe administrativa e financeiro - Estudo de Caso 3...........109

Figura 45 - Organograma da equipe de suprimentos e custos - Estudo de Caso 3...............109

Figura 46 - Organograma da equipe de segurança, meio ambiente e saúde - Estudo de Caso

3.

Figura 47 - Organograma da equipe de qualidade - Estudo de Caso 3...............................110

Figura 48 - Organograma da equipe de projeto - Estudo de Caso 3....................................111

Figura 49 - Organograma da equipe de comissionamento - Estudo de Caso 3.....................111

Figura 50 - Curva de avanço físico (engenharia, obra civil e montagem) - Estudo de Caso

3

Figura 51 - Curva de avanço físico geral - Estudo de Caso 3...............................................114

Figura 52 - Abrigo dos painéis - Estudo de Caso 3..........................................................116

Figura 53 - Abrigo dos painéis - Estudo de Caso 3 ...........................................................117 


\section{LISTA DE TABELAS}

Tabela 1 - Caracterização das empresas estudadas.............................................................. 70

Tabela 2 - Caracterização dos Estudos de Caso...................................................................118

\section{LISTA DE QUADROS}

Quadro 1 - Vantagens e Desvantagens da Estrutura Funcional...........................................51

Quadro 2 - Vantagens e Desvantagens da Estrutura Matricial.............................................52

Quadro 3 - Vantagens e Desvantagens da Estrutura Projetizada............................................55

Quadro 4 - Solicitações de Alterações de Escopo - Caso 2 ...................................................85

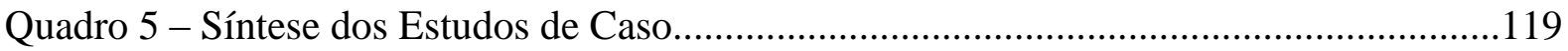




\section{SUMÁRIO}

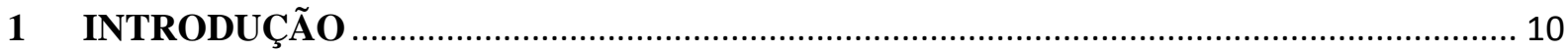

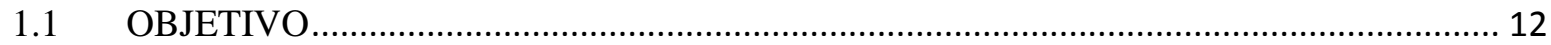

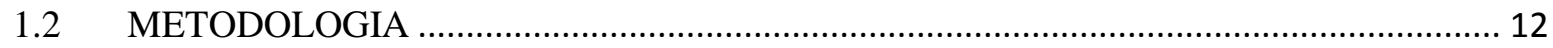

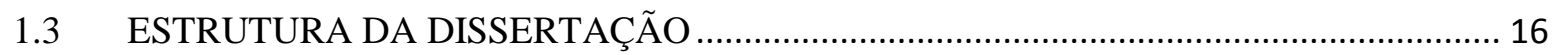

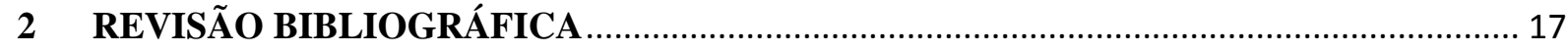

2.1 GESTÃO DE PROJETOS: PROJECT MANAGEMENT OU DESIGN MANAGEMENT? .. 17

2.1.1 Project management - gestão de projetos ….......................................................... 17

2.1.2 Design management - gestão do processo de projeto ……………............................ 20

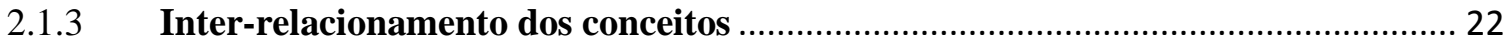

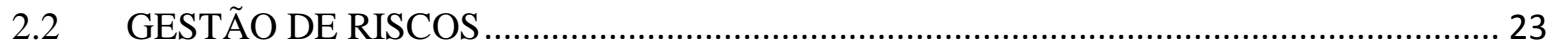

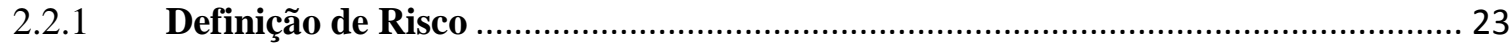

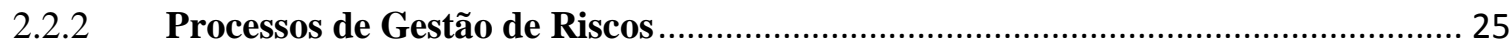

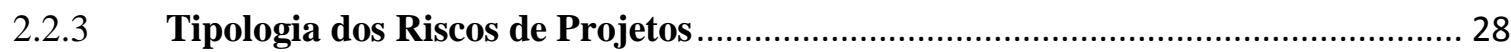

2.3 GESTÃO DO PROCESSO DE PROJETO (DESIGN MANAGEMENT) ............................ 31

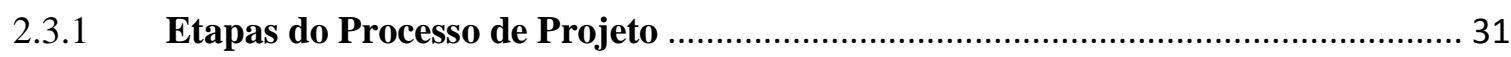

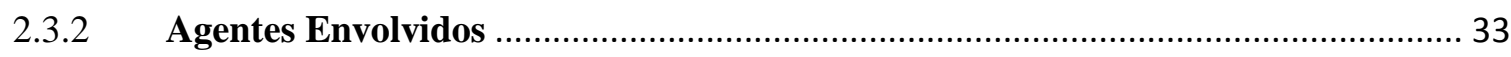

2.3.3 Gestão de Projetos, Coordenação de Projetos e Equipe Multidisciplinar.............. 35

2.3.4 BIM (Building Information Modeling) ……............................................................. 40

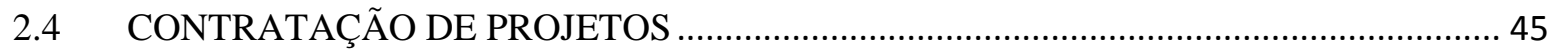

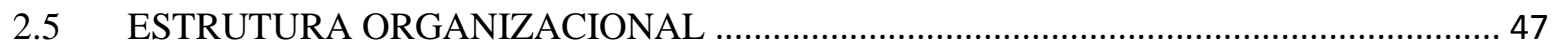

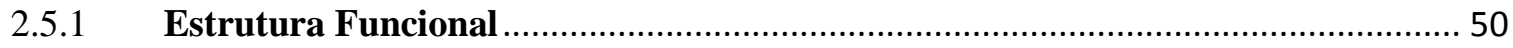

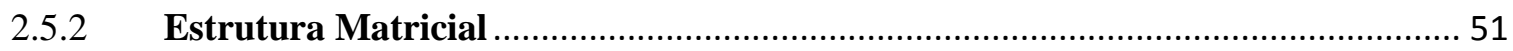

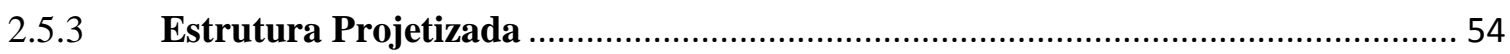

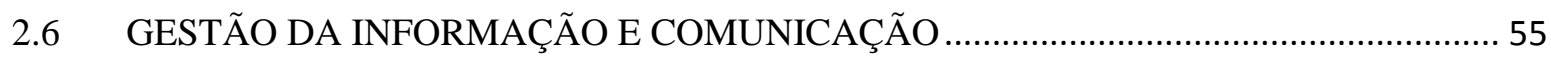

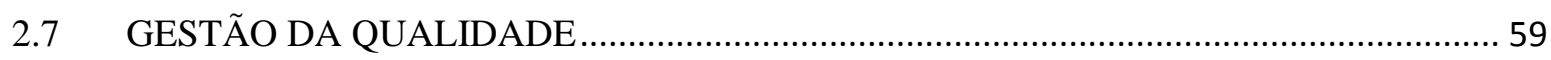

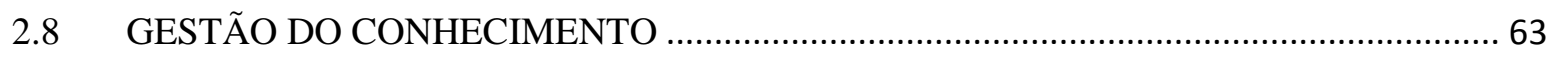

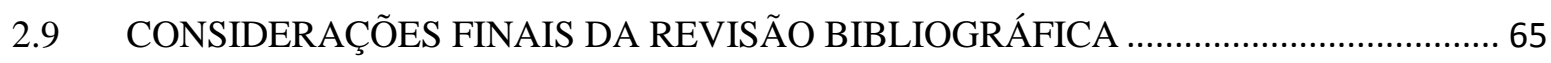

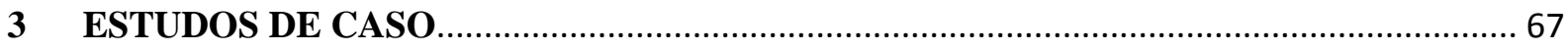

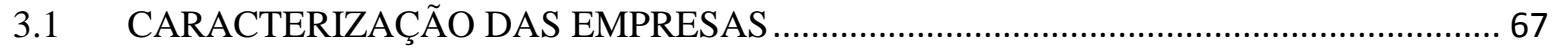

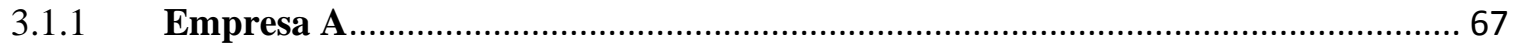

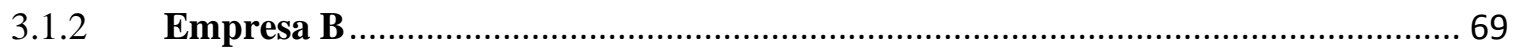




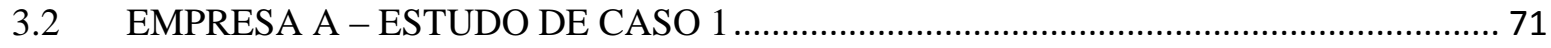

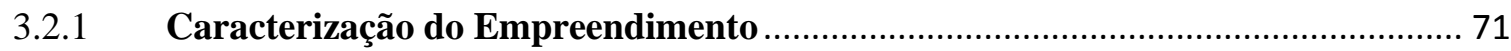

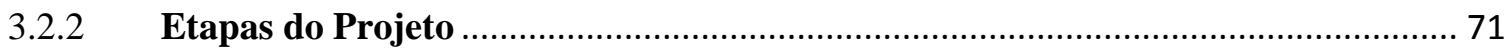

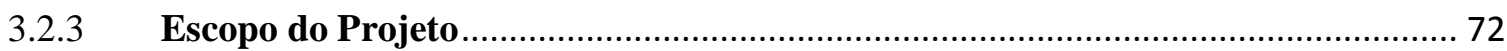

3.2.4 Agentes Envolvidos e Organograma do Empreendimento........................................ 73

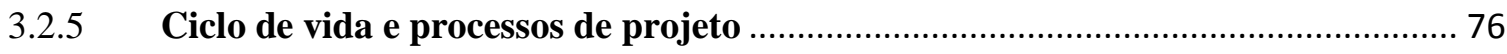

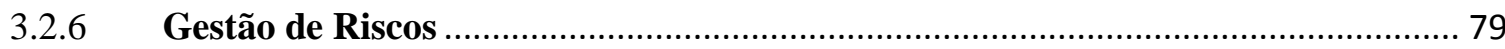

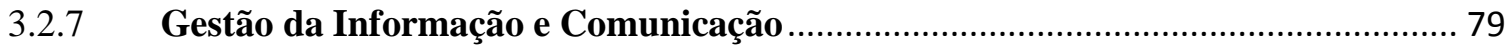

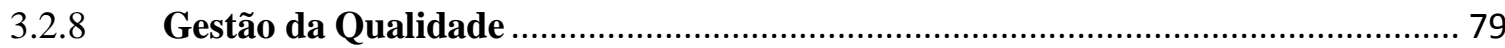

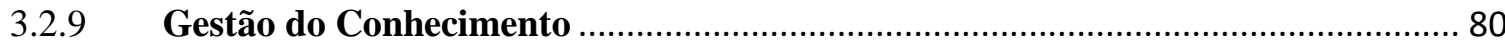

3.2.10 Relação com os agentes de produção (execução) ……………………................... 80

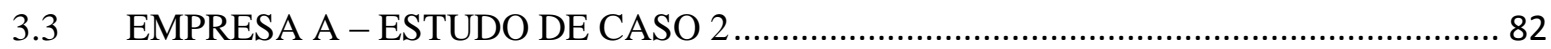

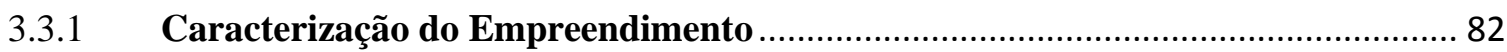

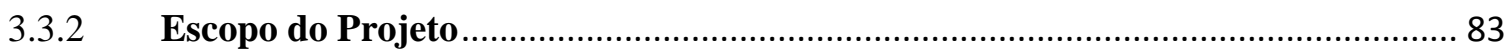

3.3.3 Agentes Envolvidos e Organograma do Empreendimento ...................................... 86

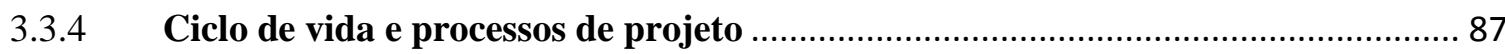

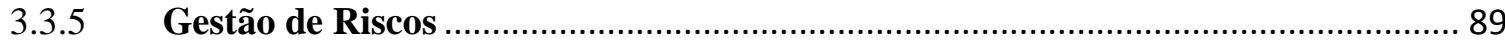

3.3.6 Gestão da Informação e Comunicação (Interface Projeto - Obra) ……………..... 90

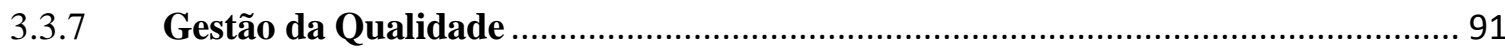

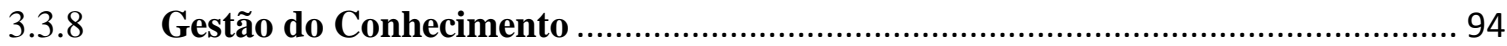

3.3.9 Relação com os agentes de produção (execução) .................................................... 94

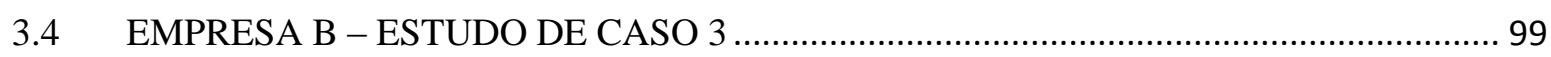

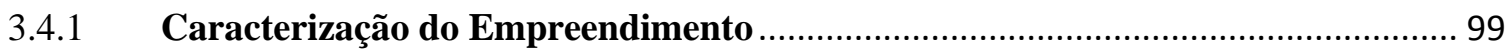

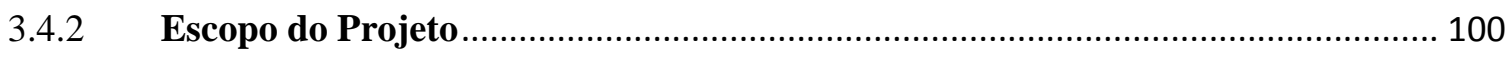

3.4.3 Agentes Envolvidos e Organograma do Empreendimento................................... 102

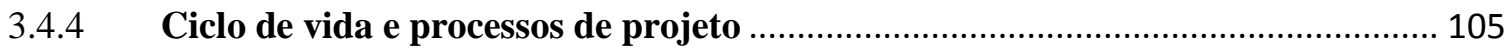

3.4.5 Os agentes do Empreendimento........................................................................ 106

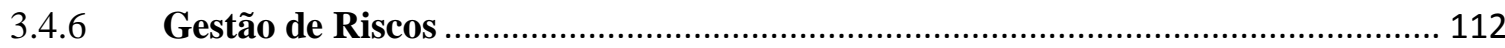

3.4.7 Gestão da Informação e Comunicação (Interface Projeto - Obra) …................... 112

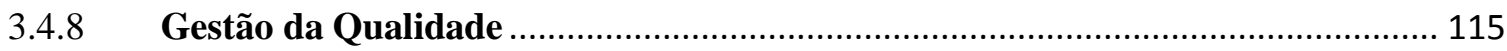

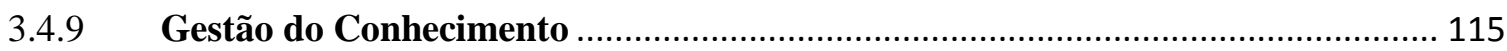

3.4.10 Relação com os agentes da produção (execução) ................................................ 115

3.5 ANÁLISES E COMPARAÇÕES ENTRE OS ESTUDOS DE CASO ............................... 117 


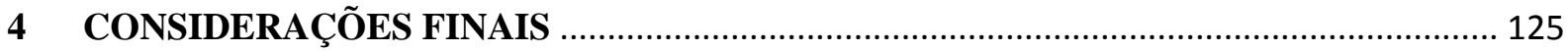

4.1 CONSIDERAÇÕES ACERCA DOS RESULTADOS DA PESQUISA ….......................... 125

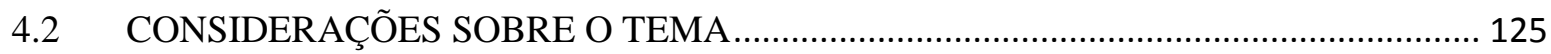

4.3 SUGESTÕES PARA FUTURAS PESQUISAS RELACIONADAS …............................... 126

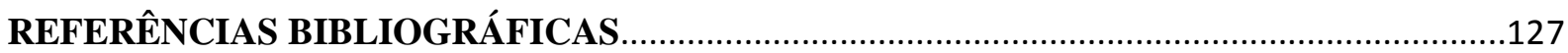

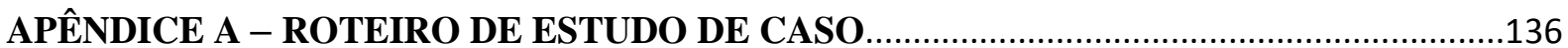




\section{INTRODUÇÃO}

Vários autores comprovam a importância da atividade de projeto para o desenvolvimento de um empreendimento. De forma a atender as crescentes exigências do mercado, ações para a melhoria, garantia e controle da qualidade do projeto são imprescindíveis.

Os empreendimentos industriais mobilizam diferentes especialidades na concepção e desenvolvimento de seus projetos. As particularidades determinam as atuações de cada agente envolvido. São eles: clientes, profissionais de projeto, consultores e construtores, cada qual com seus objetivos e perspectivas particulares. Segundo Grilo (2002), clientes demandam conformidade com o cronograma, orçamento e a qualidade especificada; projetistas buscam geração imediata e contínua de receita, reconhecimento profissional e emprego mínimo de recursos; construtores procuram meios e métodos viáveis, com um cronograma factível, um canteiro seguro e uma rentabilidade adequada.

As dificuldades técnicas e comerciais entre clientes e projetistas se iniciam logo nas contratações. Segundo Melhado et al. (2006), pode-se dizer que há poucos elementos reconhecidamente aceitos para a definição do conteúdo dos projetos a serem entregues e dos serviços a serem prestados pelos projetistas - faltam referências para escopo de serviços de

projeto. É muito comum a falta de clareza por parte dos clientes de propósitos e objetivos a serem alcançados, dificultando a definição e o entendimento do escopo dos projetos.

Além disso, a maioria dos clientes não disponibiliza às empresas projetistas, no início do projeto, informações de referências confiáveis, o que dificulta o processo de gestão. Muitas premissas são adotadas como dados reais gerando incertezas e estas, por sua vez, aumentam a probabilidade de ocorrer eventos indesejáveis que possam afetar os objetivos e performance do projeto.

De forma a consociar estes intervenientes, elaborar projetos com maior qualidade e produtividade e atingir os objetivos desejados, é necessária uma eficiente coordenação do processo de projeto.

A coordenação de projetos é uma atividade de suporte ao desenvolvimento do processo de projeto voltada à integração dos requisitos e das decisões de projeto (MELHADO, 2004). 
Devido às diferentes características das empresas do setor, existem no mercado práticas distintas na realização da coordenação. É fundamental para uma gestão do processo de projeto realmente eficaz, dispor dessa coordenação que busca atender às estratégias e diretrizes do empreendimento e promover, efetivamente, a máxima integração entre os intervenientes desse processo heterogêneo (Silva; Novaes, 2008). De acordo com Fabricio et al. (2003), as responsabilidades e habilidades típicas do coordenador de projetos envolvem iniciar o processo de projeto, planejar o processo, gerenciar a equipe de projeto, coordenar as decisões, garantir a compatibilidade entre as soluções dos vários projetos e controlar os fluxos de informação entre projetistas. Segundo Bennis e Nanus (1985), um dos importantes fatores de sucesso de um projeto é o papel do gerente de projeto como líder. Líderes possuem a responsabilidade de influenciar e conduzir a direção, ações e opiniões do projeto. Nem todos os gerentes são líderes, pois gerentes são aqueles que fazem as coisas direito e líderes são aqueles que fazem as coisas certas.

Em busca de pesquisas voltadas ao processo de projeto, são encontrados em grande maioria estudos relacionados a projetos imobiliários ou habitacionais, mas poucos referentes a outros segmentos de construção. Dentro dessa orientação predominante, autores como Silvio B. Melhado, Márcio M. Fabrício, Eliane Adesse, Janayna P. R. de Aquino, entre outros, desenvolveram trabalhos no que diz respeito à gestão do processo de projeto. ${ }^{1}$

Estudos realizados no Brasil e voltados aos projetos industriais ainda são em minoria, ou seja, há poucos trabalhos desenvolvidos e publicados com este tema, porém estes tendem a complementar e contribuir com as literaturas já existentes no que diz respeito à melhoria dos processos e qualidade dos projetos de diferentes segmentos. Dentre a bibliografia relacionada a projetos industriais, ou de natureza similar, tem-se, por exemplo, as pesquisas como a dissertação de Leonardo Grilo e o artigo de Leandro Patah e Prof ${ }^{\mathrm{a}}$ Dr$^{\mathrm{a}}$ Marly Monteiro. ${ }^{2}$

\footnotetext{
${ }^{1}$ Alguns trabalhos desses autores:

Fabricio e Melhado (2001);

Fabricio e Melhado (2012);

Adesse (2004);

Aquino e Melhado (2001).

2 Grilo (2002);

Patah e Carvalho (2002).
} 


\subsection{OBJETIVO}

Este trabalho tem como objetivo identificar, por meio de estudos de caso, as etapas de gestão utilizadas em projetos industriais, caracterizar o seu processo de projeto, assim como analisar a atuação dos gestores de projetos. Esses fatores serão analisados de uma forma ampla, com o intuito de se descreverem as práticas de gestão aplicadas aos projetos desse segmento, já que se trata de um campo em que existem poucos trabalhos de pesquisa realizados no Brasil. Dessa forma, será possível identificar os pontos críticos e dificuldades verificadas na gestão do processo de projeto e propor diretrizes aos agentes envolvidos, visando à melhoria contínua dos processos e a potencializar o sucesso na gestão de projetos industriais.

\subsection{METODOLOGIA}

De forma a atingir os objetivos propostos, o trabalho está sendo realizado em três fases que se sobrepõem: a primeira fase corresponde a uma revisão bibliográfica de conceitos relevantes para este estudo como, gestão do processo de projeto, métodos de coordenação de projetos e suas interfaces com os projetistas, escopo de projetos e de coordenação de projetos e perfil do coordenador de projetos; a segunda corresponde a uma avaliação de estudos de caso, visando identificar o processo de gestão descrito anteriormente utilizado em projetos industriais e estabelecendo uma ligação com a literatura estudada; a terceira e última fase corresponde à reflexão sobre os principais pontos críticos identificados.

\section{Pesquisa Bibliográfica}

A pesquisa bibliográfica representa o referencial teórico do desenvolvimento da pesquisa. Por meio de levantamento de referências de dissertações, teses, artigos científicos, livros e websites estão sendo pesquisados os conceitos relevantes para este estudo como, gestão do processo de projeto, etapas do processo de projeto, gestão de riscos, estruturas organizacionais, gestão da comunicação, da qualidade e do conhecimento.

\section{Estudo de Caso}

O objetivo desta etapa da pesquisa é conhecer a realidade dos processos de projeto e métodos utilizados para a gestão de empresas atuantes no seguimento de projetos industriais. De 
formar a atingir esse objetivo, nesta etapa do trabalho foi utilizado o método de estudo de caso de três diferentes projetos e duas empresas atuantes no setor.

Para a seleção das empresas e projetos a serem estudados, foram levadas em consideração as informações prévias sobre a organização e o modelo de gestão que essas organizações já mantém em seus processos, ou seja, as empresas a serem estudadas precisariam ao menos ter uma estrutura de gestão de trabalho bem definida, como estrutura organizacional, fluxo de processos e procedimentos para o processo de projeto. Também foram consideradas questões como disponibilidade das empresas para fornecer informações e participar de entrevistas. Já para a seleção dos estudos de caso, primeiramente foi realizada uma análise prévia dos casos possíveis a serem analisados, como por exemplo, a fase em que se encontravam, histórico de fatos relacionados aos casos e disponibilidade dos colaboradores envolvidos para participar das entrevistas. A partir dessa análise, os casos foram selecionados e o processo de coleta de dados e informações iniciado.

De acordo com Yin (2001), estudos de caso podem ser considerados como uma das ferramentas possíveis para a realização de pesquisas. Esse tipo de ferramenta deve ser utilizado quando se pretende conhecer as características de eventos contemporâneos da vida real, principalmente quando o foco da pesquisa são as questões de "como" e "porque" determinados eventos ocorrem, sobre os quais o pesquisador possui pouco ou nenhum controle.

O número de empresas a serem estudadas deveu-se à opção de se avaliar cada caso minuciosamente de forma a realizar um estudo qualitativo nesta etapa da pesquisa.

O planejamento e estruturação dos estudos de caso foram baseados em Yin (2001) e Miguel (2007), que sugere a condução do estudo de caso conforme a Figura 1. 
Figura 1 - Condução do Estudo de Caso

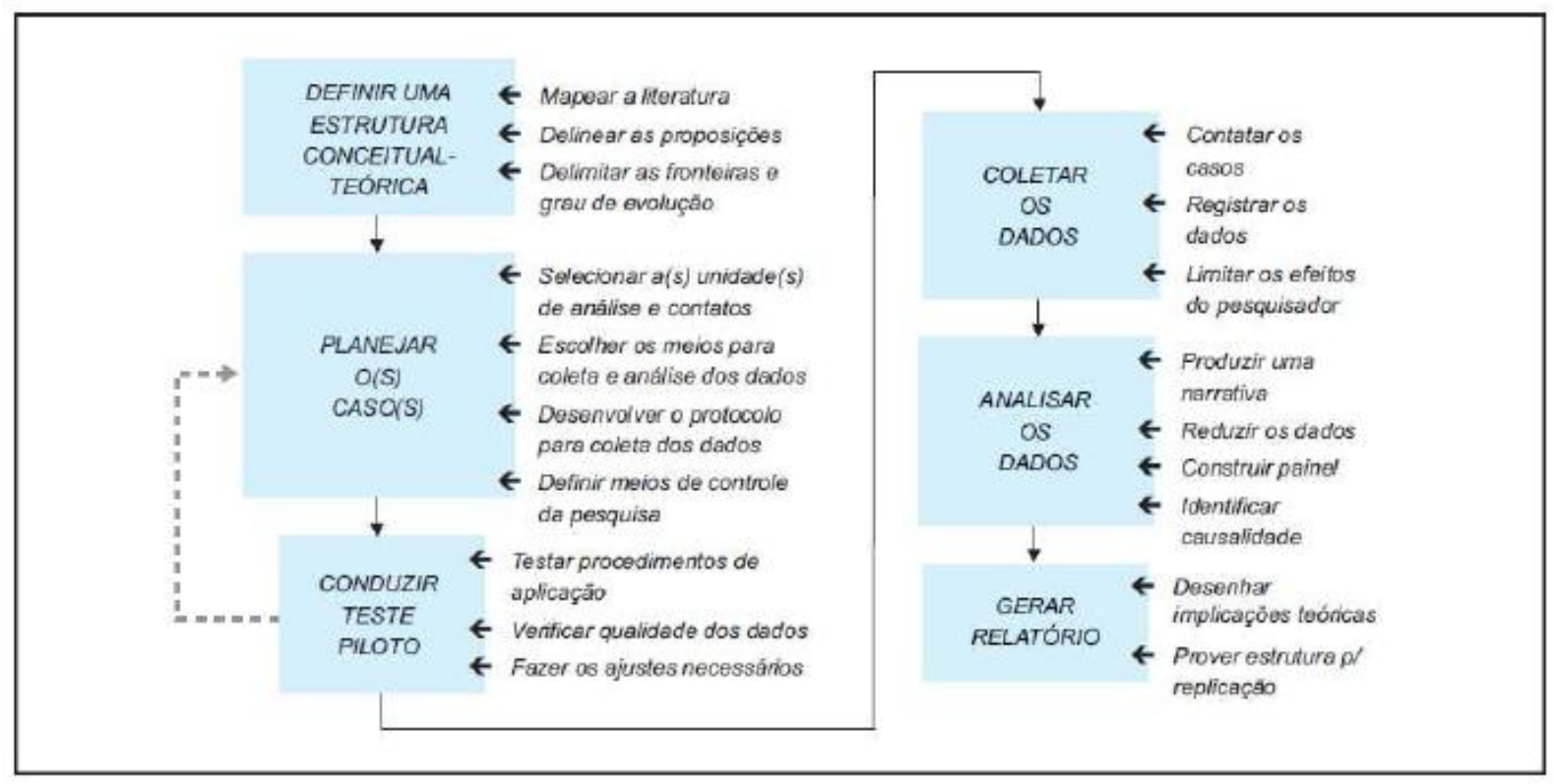

Fonte: Miguel (2007)

A coleta de dados para os estudos de caso foi realizada de diversas formas: entrevistas semiestruturadas, observações estruturadas e análise documental por meio de procedimentos de coleta, a saber:

- Locais a serem visitados: listagem das empresas e os respectivos contatos (fontes de informações);

- Plano de coleta de atividades: agenda das atividades como data das visitas, tempo para as visitas e dados dos entrevistados (informações para contato);

- Contato com as fontes de informação: o primeiro contato com a empresa foi realizado para solicitar autorização do desenvolvimento e apresentação do estudo de caso.

- Unidades de análise: empresas atuantes no seguimento de projetos industriais que possuam sede / filial na cidade de São Paulo.

As entrevistas semi-estruturadas foram elaboradas com os gerentes de projeto, colaboradores da área de planejamento envolvidos no processo de projeto e agentes técnicos participantes do estudo de caso. Para a coleta de informações e dados com intuito de caracterizar o processo de 
projeto realizado pelas empresas estudadas, foi elaborado um roteiro para as entrevistas baseado nas referências bibliográficas, que consta no Apêndice A. Este roteiro compreende informações das características da empresa como ramo / segmento, estrutura organizacional, porte / número de funcionários entre outras, o planejamento do projeto / estudo de caso estudado, integração entre os agentes, sistemas de gestão e outras informações relevantes para o estudo de cada caso.

Também foram analisadas documentações em relação aos procedimentos de processo de projeto das empresas e dados dos estudos de caso, como:

- Instruções de trabalho, procedimentos e normas internas relacionadas à gestão e coordenação;

- Evidências de gestão e planejamento / controle dos projetos (atas de reunião, relatórios de controle, cronogramas, avaliação do projeto, manual de coordenação, entre outros);

- Documentos técnicos dos casos (layouts, fluxogramas, plantas, etc.);

- Documentos relacionados ao fluxo de informação / comunicação nas empresas, como controle e distribuição de documentação.

Foram realizadas observações diretas através de visitas tanto na empresa quanto na obra, quando possível. O objetivo das visitas era verificar a atuação do gestor de projetos frente às atividades e dificuldades do dia a dia e a interação entre equipe de obra e projeto.

Por meio do primeiro estudo de caso (considerado como "estudo de caso piloto") o plano de trabalho, com a coleta de dados, análise e estruturação das informações, foi aprimorado com intuito de utilizar as lições aprendidas como experiência no desenvolvimento dos outros dois casos estudados. O critério da utilização do primeiro caso como "piloto" foi a facilidade de acesso às informações.

Com base na experiência desse estudo de caso piloto foi realizada a reformulação do questionário (acréscimo e revisão de questões com intuito de evitar falhas de interpretação), avaliação do tempo despendido nas entrevistas, assim como a verificação das informações e dados obtidos no sentido de satisfazer às necessidades da pesquisa. 
Após a conclusão do processo de coleta de informação dos três casos, os dados obtidos foram analisados e em seguida foi realizado um estudo comparativo entre as evidências e a literatura estudada.

\subsection{ESTRUTURA DA DISSERTAÇÃO}

O conteúdo desta dissertação está estruturado em quatro capítulos:

O capítulo 1 apresentada a introdução, o objetivo do trabalho, a metodologia da pesquisa (sendo destacados os critérios utilizados para a seleção das empresas e escolha dos estudos de casos) e a estrutura da dissertação.

O capítulo 2 apresenta a revisão bibliográfica abordando os principais conceitos da gestão de projetos, gestão de riscos, gestão do processo de projeto, a contratação de projeto, estrutura organizacional, gestão da informação e comunicação, gestão da qualidade, gestão do conhecimento e, por último, são apresentadas as considerações finais da revisão bibliográfica.

O capítulo 3 apresenta os estudos de caso, objeto de pesquisa desta dissertação. É iniciado pela caracterização das duas empresas selecionadas e em seguida são descritos os dados dos três casos estudados realizando uma ligação com cada item da revisão bibliográfica. Ao final do capítulo, a análise e comparação entre os três casos é apresentada, bem como diretrizes para a gestão de projetos.

O capítulo 4 apresenta as principais considerações sobre o resultado do trabalho, as contribuições da pesquisa realizada e a proposição para a continuidade e novas pesquisas. 


\section{REVISÃO BIBLIOGRÁFICA}

\subsection{GESTÃO DE PROJETOS: PROJECT MANAGEMENT OU DESIGN MANAGEMENT?}

\subsubsection{Project management - gestão de projetos}

A gestão de projetos tornou-se recentemente um fator chave em vários campos da engenharia. A proliferação de grandes projetos mundiais com objetivo de aproveitar as vantagens dos últimos desenvolvimentos tecnológicos trouxe a demanda por novos ou aperfeiçoados métodos da gestão de projetos para lidar com esse rápido crescimento industrial (EL-REEDY, 2012).

A gestão de projetos (project management) pode ser definida como o planejamento, a programação e o controle de uma série de tarefas integradas de forma a atingir seus objetivos com êxito, para benefício dos participantes do projeto (KERZNER, 2004).

Kerzner (2004) afirma que, dentro do planejamento, as principais atividades de gestão são: definição de requisitos, da qualidade, da quantidade de trabalho e dos recursos necessários. Como monitoração, as principais atividades são: acompanhamento do progresso, comparação de resultados reais com resultados planejados, análise de impactos e ajustes. Uma série de obstáculos pode impedir que os benefícios dos projetos sejam atingidos: complexidade do projeto, mudanças de escopo; reestruturações organizacionais; riscos do projeto e mudanças tecnológicas.

O PMBoK (2008) defende que, para a gestão de um projeto (project management) ser bemsucedida, é preciso a aplicação do conhecimento de técnicas, ferramentas e habilidades no trato com pessoas e clientes, e também técnicas de detalhamento das atividades do projeto a fim de atender aos requisitos do cliente. Portanto, a Gestão de Projetos é baseada em processos que asseguram a aplicabilidade do conhecimento, habilidades, ferramentas e técnicas que recebem informações e geram resultados. Assim, esses processos são agregados em cinco grupos e definidos como os Grupos de Processos em Gestão de Projetos:

Grupos de Processos de Iniciação: consiste nos processos realizados para definir um novo projeto ou uma nova fase de um projeto existente, obtendo autorização para tal. Nos processos de iniciação, o escopo inicial é definido, os recursos financeiros iniciais são comprometidos e 
os agentes internos e externos que vão interagir e influenciar o resultado geral do projeto são identificados. Se ainda não foi designado, o gerente do projeto será selecionado. Em geral, o envolvimento dos clientes e de outros agentes durante a iniciação aumenta a probabilidade de propriedade compartilhada, aceitação da entrega e obtenção de alto nível de satisfação do cliente contratante e dos demais agentes envolvidos.

Grupos de Processos de Planejamento: consiste nos processos realizados para estabelecer o escopo total do esforço, definir e refinar os objetivos, e desenvolver o curso de ação necessário para alcançar esses objetivos. Mudanças significativas ocorridas ao longo do ciclo de vida do projeto acionam uma necessidade de revisitar um ou mais dos processos de planejamento e, possivelmente, alguns dos processos de iniciação. Este detalhamento progressivo do plano de gestão do projeto com frequência é denominado "planejamento por ondas sucessivas", indicando que o planejamento e a documentação são processos iterativos e contínuos. O plano de gestão e os documentos do projeto desenvolvidos como saídas do grupo de processos de planejamento explorarão todos os aspectos de escopo, tempo, custos, qualidade, comunicação, risco e aquisições.

Grupos de Processos de Execução: consiste nos processos realizados para concluir o trabalho definido no plano de gestão do projeto de forma a cumprir as especificações do projeto. Este grupo de processos envolve coordenar pessoas e recursos, e também integrar e executar as atividades do projeto em conformidade com o plano de gestão. Durante a execução do projeto, os resultados poderão requerer atualizações no planejamento e mudanças nas linhas de base. Isso pode incluir mudanças nas durações previstas para as atividades, na produtividade e na disponibilidade dos recursos, bem como riscos imprevistos. Essas variações podem exigir uma análise detalhada e o desenvolvimento de respostas apropriadas de gestão de projetos.

Grupos de Processos de Monitoramento e Controle: consiste nos processos necessários para acompanhar, revisar e regular o progresso e o desempenho do projeto, identificar todas as áreas nas quais serão necessárias mudanças no plano e iniciar as mudanças correspondentes. O principal benefício é que o desempenho do projeto é observado e mensurado de forma periódica e uniforme para identificar variações em relação ao plano de gestão. 
Grupos de Processos de Encerramento: consiste nos processos executados para finalizar todas as atividades de todos os grupos de processos de gestão do projeto, visando completar formalmente o projeto ou a fase, ou atender a obrigações contratuais.

O processo de projeto, portanto, constitui-se de ações e atividades inter-relacionadas que são realizadas de forma a obter um conjunto, definido por produtos, resultados ou serviços. A atuação conjunta dos grupos de processos é necessária em qualquer projeto (Figura 2), pois eles possuem "claras dependências internas e devem ser realizados na mesma sequência em cada projeto, independentemente da área de aplicação ou das especificações do ciclo de vida do projeto aplicado" (PMBoK, 2004).

Figura 2 - Ligações entre os grupos de processos na gestão de projetos

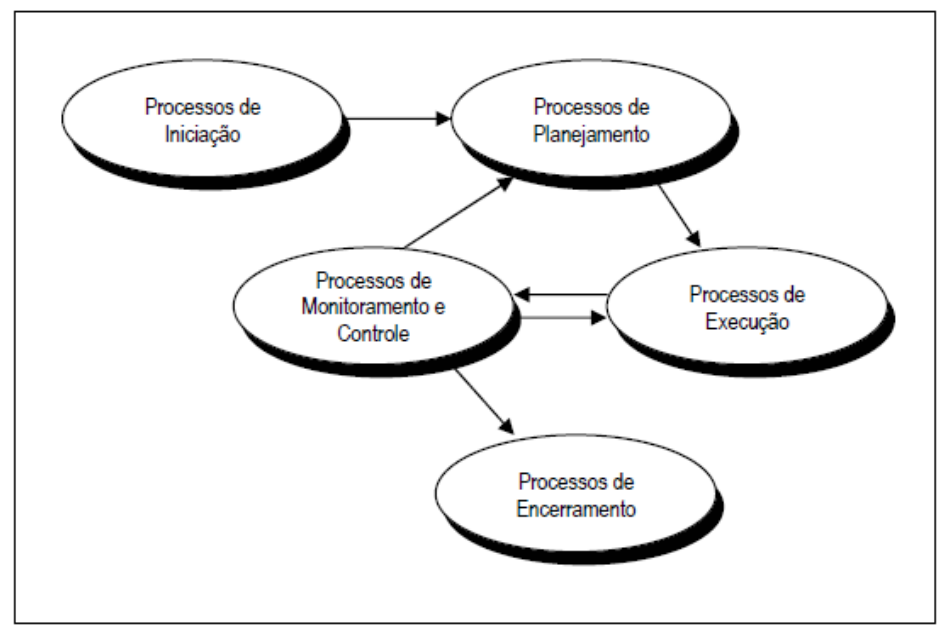

Fonte: PMBoK (2004)

De acordo com Coelho (2006), gestão de projetos é um ambiente integrador, e esta integração exige que cada processo seja associado e conectado a outros processos para facilitar a sua coordenação.

No início dos projetos, são os processos de iniciação que consomem a maioria dos recursos. Com o decorrer do tempo, os processos de planejamento, seguidos dos processos de execução e, finalmente, dos processos de encerramento, passam a consumir mais recursos (Figura 3). 
Esse conjunto de processos pode se referir ao empreendimento como um todo (project), ao projeto (design), à execução da obra ou a todos esses. O que implica, neste último caso, uma sequência de fases de iniciação, planejamento, execução, controle e encerramento encadeadas.

Figura 3 - Integração de Grupos de Processos em um Projeto

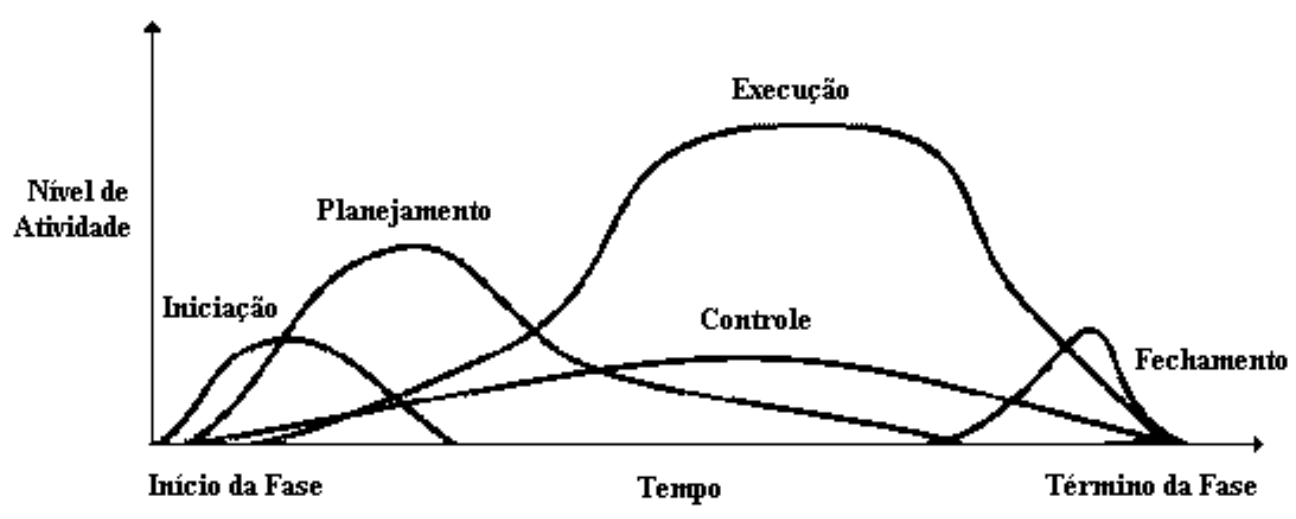

Fonte: PMBok (2004)

\subsubsection{Design management - gestão do processo de projeto}

A gestão do processo de projeto (design management) tem sido destacada por diversos autores como fator determinante na melhoria dos processos e produtos da construção civil. Por se tratar de um processo envolvido ainda na concepção do produto, é por meio dele que muitas decisões podem ser tomadas e falhas podem ser evitadas com uma menor demanda de custos. Apesar disso, em diversas pesquisas realizadas no setor, o item projeto foi avaliado como crítico em relação à qualidade dos empreendimentos (SILVA, 2011). Isto se deve, entre outros fatores, à pouca importância com que a fase de projeto ainda é vista pelos empreendedores. Segundo Fontenelle (2002), a fase de projeto é tratada como "custo", um ônus do empreendedor, e não como um "investimento", com retorno garantido em termos de elevação dos níveis de qualidade e produtividade de todos os processos subsequentes.

De acordo com Han et al (2013), apesar dos avanços na construção e nas técnicas de gestão, os grandes atrasos no cronograma e o aumento de custos ainda persistem no desenvolvimento de projetos. Erros e/ou alterações de projeto levam a retrabalho e o retrabalho tem sido 
identificado como um problema endêmico na construção e projetos de engenharia e um dos principais contribuintes para os atrasos de cronograma e custos adicionais face ao orçamento.

Muitos autores afirmam que, embora a fase de projeto represente os menores custos do empreendimento, as decisões tomadas nesta fase são as que mais possuem capacidade de influenciar todas as fases posteriores. Apesar de baixo dispêndio de recursos, na fase de projeto concentram-se boa parte das chances de redução da incidência de falhas e dos respectivos custos (MELHADO, 1994). Na Figura 4 é possível observar que a fase de projeto possui maior capacidade de influenciar os custos totais do empreendimento devido à possibilidade de identificar e corrigir as falhas antes do início da construção.

Figura 4 - $\mathrm{O}$ avanço do empreendimento em relação

à chance de reduzir o custo de falhas do edifício

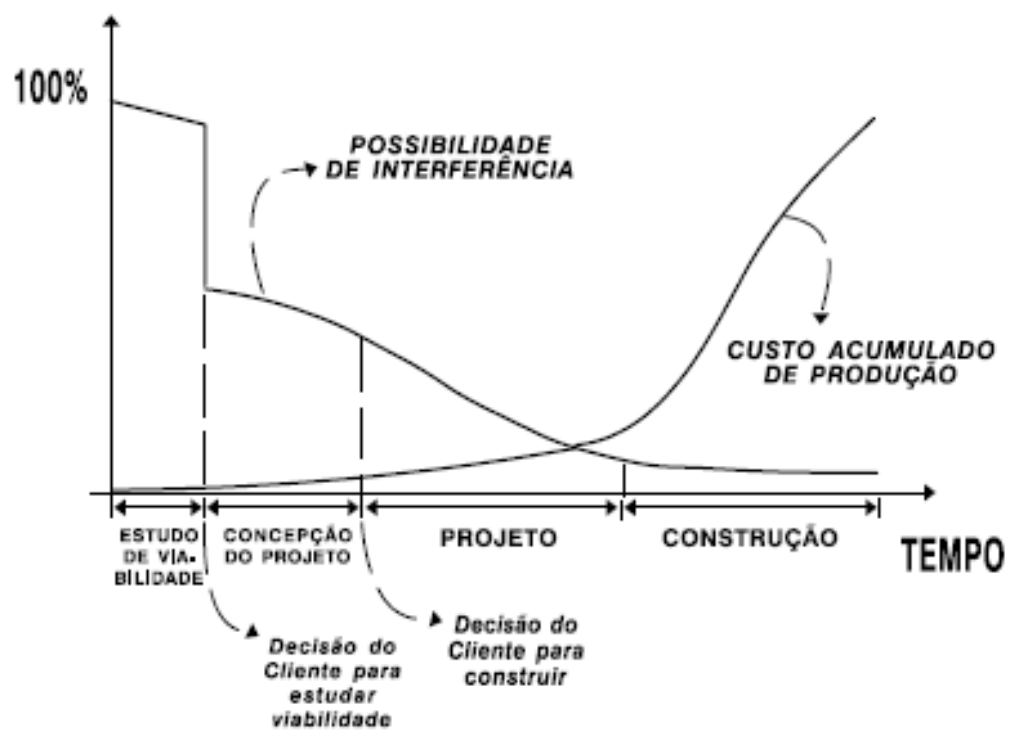

Fonte: Hammarlund; Josephson, 1992 apud Melhado, 1994

De acordo com Oliveira (2005), quanto mais cedo forem detectados os potenciais problemas relativos à execução, a partir das informações fornecidas pelos empreendedores e do amadurecimento das soluções de projeto, maior será a capacidade de influenciar positivamente os custos do empreendimento, desde que implantadas as soluções pertinentes. 


\subsubsection{Inter-relacionamento dos conceitos}

Segundo Nóbrega Júnior (2012), fora da literatura da construção civil o termo design management é usado para designar a coordenação apenas dos desenhos de um projeto, depois que a coordenação do projeto (enquanto empreendimento), project management, termina. Emmitt (2007) afirma que a ênfase do design management está não apenas na coordenação dos desenhos, mas no ciclo de vida completo dos projetos, estendendo-se, inclusive, ao relacionamento dos projetos com todos os envolvidos. O termo coordenação de projetos é usado para se fazer referência a uma série de atividades, incluindo as funções de coordenação de projetos e o serviço profissional da empresa de coordenação (Figura 5).

Em um empreendimento de construção de certa complexidade, o project management e o design management estarão inter-relacionados, mas serão desenvolvidos por profissionais distintos. O project management, mais abrangente, estará ligado ao empreendimento, ao negócio; enquanto o design management, menos abrangente, terá foco mais técnico e ênfase no desenvolvimento das soluções de projeto. Isso não impedirá, como já foi dito, que se usem, em ambos, alguns processos de gestão similares.

Figura 5 - Entendimento da relação entre project management e design management no setor industrial

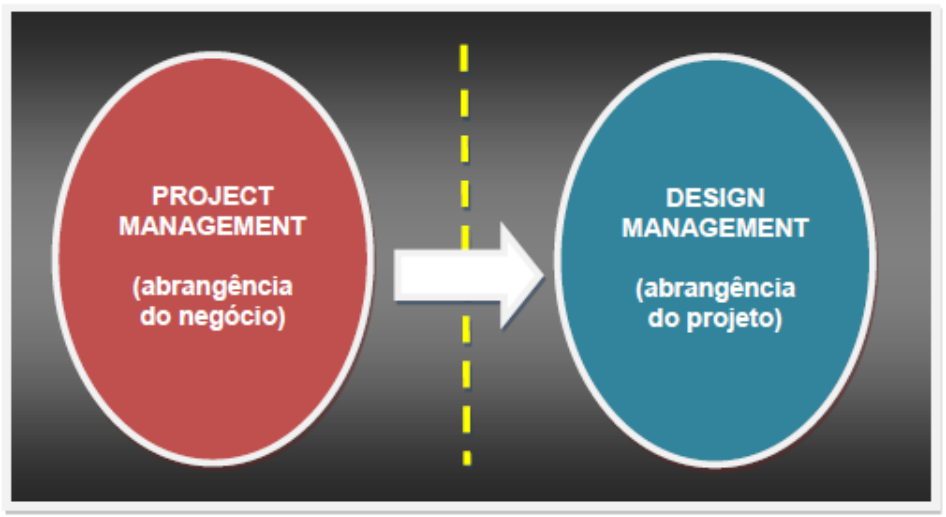

Fonte: Nóbrega Júnior (2012) 


\subsection{GESTÃO DE RISCOS}

\subsubsection{Definição de Risco}

A gestão de riscos vem ganhando maior espaço e atenção no âmbito da gestão de projetos e isto se deve, entre outros fatores, às análises da gestão dos projetos como um todo e de seus resultados finais. O sucesso de um projeto, quando considerados prazo, custo e qualidade, depende em grande escala de como o projeto trata os riscos apresentados.

O conceito de risco é apresentador pela British Standard BS 6079-3:2000 como a incerteza inerente aos planos e à possibilidade de acontecer algo que possa afetar as perspectivas de se alcançarem os objetivos do projeto.

Risco é a qualidade de um sistema que está relacionada à possibilidade de diferentes resultados (SCHUYLER, 2001). Para Modarres (2006), o termo risco significa não somente a ocorrência de um evento indesejável, mas também quão provável e quais suas consequências caso ocorra.

Risco é descrito como um evento, um fato ou uma condição com certas consequências esperadas e probabilidade conhecida, o que torna possível avaliar, prever ou medir o risco, e assim planejá-lo. Risco deve ser definido de modo objetivo (PERMINOVA, 2011).

Um risco é um evento futuro que pode ou não acontecer. Muitas vezes, categorizam-se eventos passados causados por problemas ou crises. Considerando-se que esses eventos ocorreram no passado, eles não são exemplos de risco. Além de acontecer no futuro, um risco deve ser também um evento. Por isso, itens relacionados a custos, cronograma e qualidade não fazem parte da definição adotada para o que é risco, porque eles não são eventos. Porém, um evento futuro em um cronograma ou um evento futuro que avalie a qualidade de um sistema poderá ser um risco (ROVAI, 2005).

O guia PMBoK (PMI, 2008) define risco como um evento ou uma condição incerta que, se ocorrer, tem um efeito em pelo menos um objetivo do projeto, como escopo, prazo, custo ou qualidade, ou seja, é possível afirmar que os riscos em projetos se originam no campo das incertezas. Rabechini Junior e Carvalho (2013) afirmam que o risco caracteriza-se por uma situação cuja decisão é tomada sob condições de probabilidade conhecidas. No caso das 
incertezas, não é possível associar a elas valores numéricos de probabilidade, bem como há falta de conhecimentos sobre as consequências de um evento.

Assim, a Gestão de Riscos está relacionada com eventos futuros, cujo resultado exato é desconhecido, e com o modo de lidar com essas incertezas com antecedência (ROVAI, 2005).

De acordo com Thuyet, Ogunlana e Dey (2007), riscos na construção civil muitas vezes causam excessos de prazo e custo. Muitos projetos têm atrasado ou excedido seus orçamentos planejados, devido ao fato de os gerentes de projeto não conseguirem gerenciar os riscos de maneira eficaz. Esses problemas parecem acontecer com mais frequência nos dias de hoje devido à natureza da economia. Os projetos atuais estão consideravelmente mais expostos a riscos e incertezas por causa de fatores como complexidade no planejamento e no projeto, presença de vários grupos de interesse (investidores, consultores, fornecedores, etc.), disponibilidade de recursos (materiais, equipamentos, fundos, etc.), ambiente climático, preocupações sociais, bem como fatores legais, econômicos e políticos.

Os projetos industriais tendem a apresentar inúmeros e variados riscos, devido, por exemplo, à complexidade e às diferentes tecnologias que são aplicadas ao seu desenvolvimento. De acordo com Rabechini Junior e Carvalho (2013), nas dimensões de tecnologia e inovação parecem estar os aspectos mais relevantes da incerteza devido às suas naturezas, havendo, portanto, uma relação direta entre essas variáveis. Dessa forma, acredita-se que quanto maior o grau de inovação e tecnologia, maiores as incertezas envolvidas.

Em gestão de projetos, o conceito de incerteza pode estar relacionado à qualidade de informações necessárias quando de um processo decisório. Logo no inicio de um projeto, há a necessidade de se obterem informações relevantes e indispensáveis para o seu desenvolvimento. Porém, nem todas essas informações são disponibilizadas e quando o são, muitas não possuem o grau de confiabilidade necessário para planejar e executar as atividades. Diante deste contexto, a tomada de decisão de assumir riscos considerando as informações existentes é crítica para a execução do projeto. Segundo Navarro (2007), quando não há informações suficientes para a tomada de decisões ou planejamento do projeto, as premissas preenchem esses vazios. Porém, é possível que essas premissas não sejam verdadeiras, e caso isso ocorra, muito provavelmente levarão a fracassos. 
De acordo com Wideman (1992), a maioria das decisões é tomada sem o conhecimento da totalidade das informações, introduzindo um grau de incerteza sobre o resultado. Em certos casos, pode-se chegar à total falta de informação, em que nada é conhecido sobre o resultado, predominando, então, a absoluta incerteza. A Figura 6 traz o espectro do grau de incerteza presente sobre os riscos do projeto.

Figura 6 - Espectro da Incerteza

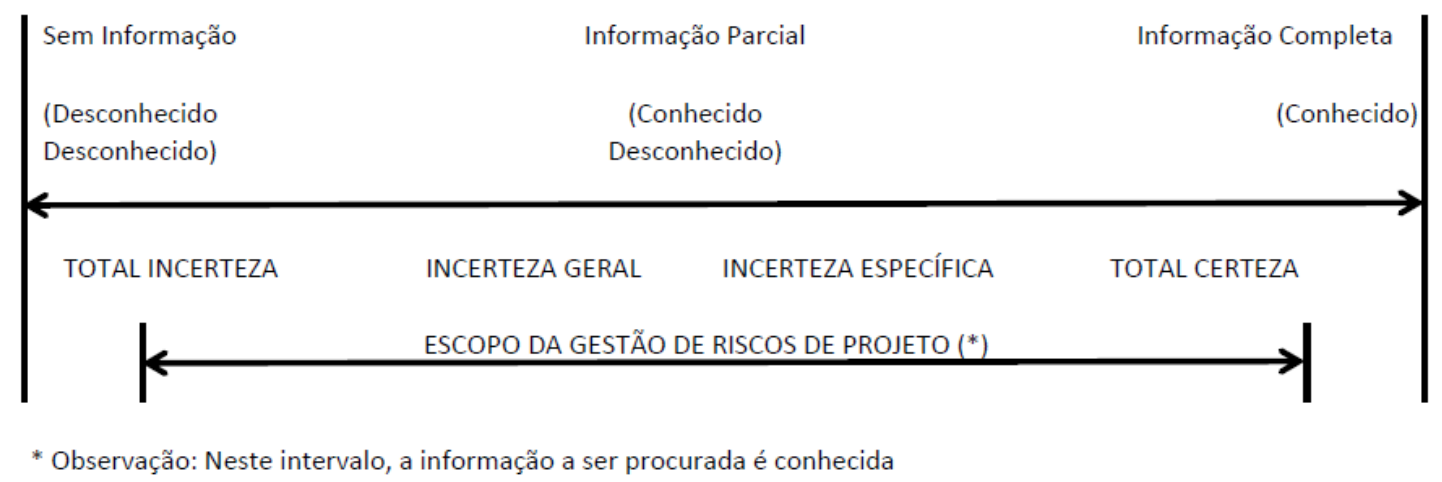

Fonte: Adaptado de Wideman (1992)

Na gestão de projetos, os eventos de risco muitas vezes são classificados como ameaças e oportunidades. Como afirma Schuyler (2001), a gestão de riscos em projetos possui o objetivo de reduzir a probabilidade e os impactos das ameaças, além de aumentar a probabilidade e os impactos das oportunidades.

\subsubsection{Processos de Gestão de Riscos}

Gestão de riscos é a arte e a ciência de planejar, avaliando (identificando e analisando), controlando e monitorando ações que conduzam a eventos futuros, para assegurar resultados favoráveis. Assim, um bom processo de gestão de riscos é naturalmente pró-ativo e é fundamentalmente diferente da gestão de crises (ou resolução de problemas), que é reativo. Um evento futuro possui uma probabilidade de ocorrer, porém quando essa probabilidade é de $0 \%$ ou $100 \%$ não podem ser considerados como risco. Uma vez que se sabe que há $100 \%$ de certeza de que um evento futuro acontecerá, então se tem um problema ou uma crise, não um risco (ROVAI, 2005). 
De acordo com PMI (2009), a gestão de riscos tem o objetivo de identificar e priorizar os riscos antes de sua ocorrência e fornece informações orientadas para ação dos gestores de projeto. Essa orientação requer considerações de eventos que podem ou não ocorrer e são, portanto, descritos em termos de probabilidade de ocorrência, além de outras dimensões, tais como seus impactos em objetivos.

A gestão de riscos é um processo, e seguir esse processo é importante para terem-se resultados em um projeto (MULCAHY, 2003). A mesma autora define os passos para o processo de gestão de riscos:

- Planejamento da gestão de riscos;

- Identificação dos riscos;

- Análises qualitativa e quantitativa dos riscos;

- Planejamento de respostas aos riscos;

- Controle e monitoramento dos riscos.

Wideman (1992) define gestão de riscos como um processo de identificação, análise, desenvolvimento de respostas e controle dos riscos de projetos, durante seu ciclo de vida e no interesse de seus objetivos (escopo, custo, prazo e qualidade). Segundo Wideman, a gestão de riscos envolve quatro fases ou processos:

- Identificação dos Riscos;

- Avaliação e Análise dos Riscos;

- Desenvolvimento de Resposta aos Riscos;

- Documentação e Controle dos Riscos.

Já o PMBOK (2008) define a gestão de riscos como parte dos processos de planejamento, identificação, análise, planejamento de respostas, monitoramento e controle. Os objetivos da 
gestão dos riscos são aumentar a probabilidade e o impacto dos eventos positivos e reduzir a probabilidade e o impacto dos impactos negativos no projeto. Abaixo o resumo dos processos de gestão dos riscos do projeto, muito semelhante ao apresentado pelos autores citados acima (Figura 7):

- Planejar a gestão dos riscos;

- Identificar os riscos;

- Realizar a análise qualitativa dos riscos;

- Realizar a análise quantitativa dos riscos;

- Planejar as respostas aos riscos;

- Monitorar e controlar os riscos.

Figura 7 - Etapas da Gestão de Riscos

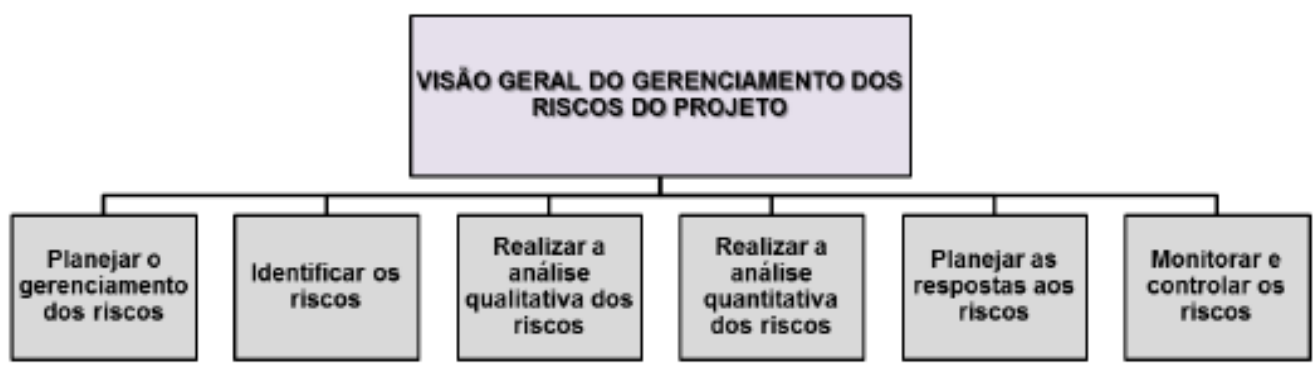

Fonte: PMBOK, 2008

Gestão de riscos em projetos não é uma atividade opcional: é essencial para o sucesso da gestão de projetos. Deve ser aplicada em todos os projetos e, consequentemente, incluída nos planos de projeto e documentos operacionais. Dessa forma, torna-se parte integral de todos os aspectos da gestão de projetos, em todas as fases e em todos os grupos de processo (PMI, 2009). 


\subsubsection{Tipologia dos Riscos de Projetos}

O Relatório Final sobre Riscos Universais em Projetos, RISKSIG - PMI (HALL; HULLET, 2002), define três grandes grupos de riscos. São eles: os riscos de gestão, riscos externos e tecnológicos, que podem ser descritos da seguinte forma:

\section{Riscos de Gestão}

Um conjunto de riscos que caracterizam a organização responsável pelo projeto, operação ou análise (simplesmente denominado "o projeto"), ou estão sob o seu controle. Estes incluem gestão de projetos, gestão do sistema e aspectos de risco de gestão organizacional. Neles estão envolvidos a condição da organização, seus recursos e cultura pessoal, tendências organizacionais, situação financeira e comunicação ou estilo da gestão. Neste grupo, para a identificação de potenciais riscos (desvio do planejado) podem ser realizados, entre outros, os seguintes tipos de questionamento: a empresa possui canais de comunicação eficazes? A organização pode tomar decisões? Existe compromisso com a elaboração de planos de projeto realistas? A empresa está comprometida a ter recursos para gerenciar os riscos? Existe compromisso com as melhores práticas em seus processos?

\section{Riscos Externos}

Um conjunto de riscos que se encontra fora do controle da organização que detém o projeto. Áreas de risco externo incluem as ações de terceiros (por exemplo, clientes, stakeholders, fornecedores, concorrentes, etc.), de forças climáticas, demografia, mercado de materiais e crescimento econômico. Também são potenciais riscos as condições metereológicas, sísmicas, mercado financeiro, questões políticas, entre outros. Uma maneira de identificar potenciais riscos externos seria por meio da análise da realização de projetos semelhantes, pois desvios quanto aos resultados planejados podem ocorrer caso não exista experiência pertinente no tipo de projeto em questão.

\section{Riscos Tecnológicos}

Um conjunto de riscos inerentes à tecnologia e processos utilizados em um projeto, produto, sistema ou análise. Riscos tecnológicos são os riscos que abrangem os recursos e tecnologias de apoio e processos de desenvolvimento de ambientes operacionais. Informações quanto à 
existência de conhecimento sobre as condições e requisitos impostos pelo projeto, assim como a capacidade de selecionar tecnologia apropriada, o conhecimento da complexidade do projeto e se as várias restrições (custo, prazo e desempenho) estabelecidas são consistentes com a aplicação e escolha da tecnologia utilizada, devem ser consideradas quando da identificação dos potenciais riscos tecnológicos em um projeto.

Wideman (1992) classifica os tipos de risco em vários grupos, e afirma que o grau de previsibilidade e a capacidade da gestão de reagir apropriadamente são variáveis, mas, em qualquer caso, são independentes da probabilidade de ocorrência e dos valores associados ao evento de risco.

A classificação de riscos estabelecida por Wideman considera os seguintes grupos:

- Riscos Externos (e incontroláveis): relacionados à vulnerabilidade dos projetos em relação às mudanças na legislação, a ações governamentais ou a desastres físicos, ambientais e climáticos.

- Riscos Externos (mas controláveis): as mudanças são previsíveis, mas a extensão e direção são incertas. São relacionados às questões de mercado (demanda, economia, competição), operacionais (após a finalização do projeto, considerando necessidade de manutenção, segurança), ou a impactos sociais, inflação e mudanças de moeda.

- Riscos Não Técnicos: relacionados à inadequação ou falta de uma estrutura organizacional, de políticas e de procedimentos apropriados; a planejamento inadequado, cronograma irreal, falta de coordenação, interrupções financeiras e deslocamento de prioridades.

- Riscos Técnicos: associados ao desenvolvimento ou melhoria de novas tecnologias, qualidade do desempenho do projeto, pelas possibilidades de uma maior eficiência do que a planejada inicialmente.

- Riscos Legais: relacionados à obtenção de licenças, ou equívocos, más interpretações e falhas contratuais.

Como resultado da pesquisa realizada por Thuyet, Ogunlana e Dey (2007), foram identificados os dez maiores riscos que afetam os projetos de construções de óleo e gás. São eles: 
- Sistema de governo burocrático e procedimento extenso para aprovação de projeto;

- Má qualidade do projeto;

- Incompetência da equipe do projeto;

- Concorrência inadequada;

- Processo de aprovação interna do proprietário demorado;

- Estrutura de projeto inadequada;

- Estudo de viabilidade do projeto inadequado;

- Ineficiência e baixa performance das construtoras;

- Planejamento e orçamento do projeto incorretos;

- Mudanças no projeto.

Esses riscos relativos à área de óleo e gás são os mesmos identificados em muitos projetos industriais. Analisando essa semelhança, independentemente da área de negócio, ou seja, a especificidade dos projetos industriais, grande parte dos riscos que podem afetar o desempenho do projeto são os mesmos.

É possível afirmar que os riscos identificados estão associados a praticamente todas as etapas do processo de projeto; por exemplo, a definição da estrutura de projeto pode afetar a disponibilidade de recursos e influenciar o planejamento das atividades a serem desenvolvidas. Além disso, a má qualidade de projeto pode induzir riscos que se manifestarão durante a fase de execução. Dessa forma, a identificação e análise dos riscos em um projeto devem ser consideradas de forma integrada, pois diferentes riscos podem ser identificados nas diferentes etapas, e esses riscos podem se combinar de forma crítica e tal combinação levar a consequências ainda mais graves.

Os autores mencionados afirmam que para um projeto ser bem sucedido é extremamente importante que os principais riscos que afetam os projetos sejam minuciosamente examinados. Suas causas e características devem ser cuidadosamente analisadas, de modo a sugerir as melhores apropriadas e exequíveis estratégias para mitigá-los e apoiar as decisões do cliente. 


\subsection{GESTÃO DO PROCESSO DE PROJETO (DESIGN MANAGEMENT)}

\subsubsection{Etapas do Processo de Projeto}

O processo de projeto é desenvolvido em várias etapas e deve proporcionar a integração entre os diversos agentes envolvidos. Segundo Bertezini (2006), o processo de projeto deve ser entendido de uma maneira mais ampla, abordando além das questões específicas de seu processo, também questões relacionadas à sua gestão e às relações com os demais processos do empreendimento (project).

De acordo com Bertezini (2006), essa subdivisão do processo de projeto em etapas é importante, pois permite que:

- sejam identificadas todas as atividades a serem realizadas durante o processo de desenvolvimento de projetos, visando atingir ao seu objetivo final;

- cada atividade tenha seu conteúdo e informações necessárias para o seu desenvolvimento bem definidas, além de seus produtos finais estabelecidos;

- sejam atribuídas responsabilidades específicas para cada atividade, o que contribui para a transparência do processo e para o fluxo de informações;

- sejam disponibilizados os recursos necessários para a execução de cada atividade, obtendose vantagens quanto a custos e prazos.

Melhado (1994) subdivide e define o processo de projeto (design) nas seguintes etapas:

- Idealização do produto: solução inicial para o atendimento do programa de necessidades e restrições iniciais;

- Análise de viabilidade: avaliação da solução sob os aspectos de custo, tecnologia, adequação ao usuário e restrições legais correspondentes, em um processo iterativo até que a solução definitiva seja encontrada, traduzida em um estudo preliminar que será a base para o desenvolvimento do projeto; 
- Formalização: a solução é consolidada, originando o anteprojeto;

- Detalhamento: elaborados em conjunto o detalhamento final do produto (Projeto Executivo) e processos de execução (Projeto para Produção);

- Planejamento e execução: planejamento das etapas de execução da obra;

- Entrega: entrega do produto ao usuário, o qual terá a assistência técnica da construtora no início e fase na qual serão coletadas informações para a retroalimentação à melhoria contínua do processo.

Figura 8 - Modelo de etapas do processo de projeto

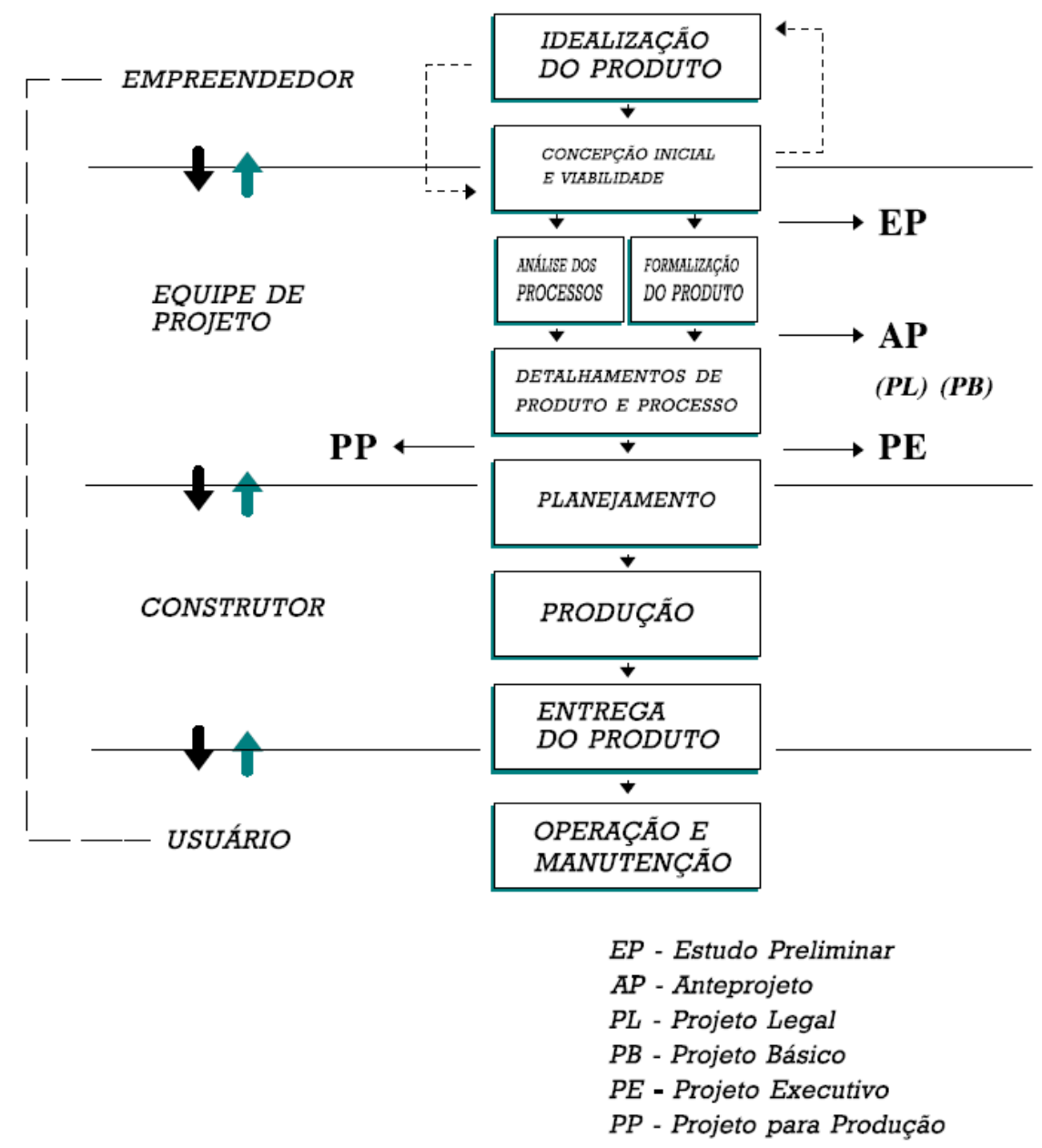

Fonte: Melhado (1994) 
Na proposta mostrada na Figura 8, o autor indica a formação da equipe de projeto como uma equipe multidisciplinar, composta por engenheiros de todas as especialidades, arquiteto, equipe de projeto para a produção, consultores especializados e coordenador de projetos; atuando a equipe em conjunto com o empreendedor, de forma a atender a todos os objetivos e expectativas deste último e do usuário final.

\subsubsection{Agentes Envolvidos}

Os empreendimentos industriais mobilizam diferentes especialidades na concepção e desenvolvimento de seus projetos. A intensificação das exigências dos clientes em termos de prazos, custos e qualidade estimula a introdução de inovações em tecnologias e métodos de gestão (GRILO, 2002). Neste cenário, o arranjo de uma equipe que privilegie a interatividade entre os agentes é de extrema relevância para que sejam atendidas essas limitações de custo, tempo e especificações do projeto exigidas.

O desenvolvimento dos projetos depende da interação entre os diversos agentes que atuam em cada etapa de seu ciclo de vida e que interferem direta ou indiretamente no processo de projeto (MEDEIROS, 2012). Os agentes de um projeto são pessoas e organizações ativamente envolvidas no projeto ou cujos interesses podem ser afetados pela realização ou pela interrupção de um dado projeto. O conjunto desses agentes também exerce influência sobre os objetivos e resultados do projeto. Em muitos trabalhos, os agentes do projeto são denominados stakeholders ou, ainda, partes interessadas.

Os projetos são realizados por equipes complexas, formadas por clientes, projetistas e construtores, com o objetivo de prover os recursos necessários para a construção, ampliação ou reforma de um edifício. Um conjunto de fatores condiciona a configuração da equipe do projeto, tais como o grau de experiência do cliente, o tipo e a complexidade do edifício, a estrutura funcional e o tipo de contrato (GRILO, 2002). Além desses, os consultores, as gerenciadoras, agências reguladoras, órgãos públicos e investidores podem compor os agentes envolvidos.

Agentes do projeto, ou stakeholders, são definidos como uma pessoa, grupo ou organização com legítimos interesses nas ações e no desempenho do projeto cujas decisões e resultados possam afetá-los. 
Em suma, podem-se citar como principais agentes envolvidos em um projeto de construção (MELHADO, 1994):

- Clientes (também denominados empreendedores, ou proprietários, em alguns casos);

- Empresas projetistas;

- Empresas construtoras (também denominadas empreiteiras, ou executores do projeto);

- Investidores (também denominados patrocinadores, em alguns casos);

- Financiadores;

- Empresas de gerenciamento (gestores atuantes em nome do cliente);

- Fornecedores;

- Subcontratados (ou terceiros);

- Órgãos de aprovação;

- Órgãos de fiscalização;

- Usuários;

- Operadores ou gestores do empreendimento (como os chamados facility managers).

Cabe à gestão de projetos a compreensão dos papéis e responsabilidades dos diversos agentes, assim como das relações entre eles. Devido à possível abrangência de compreensão em relação ao escopo do projeto entre os diversos agentes envolvidos, é preciso detalhar esse escopo direcionando os serviços a serem atribuídos a cada agente de uma maneira muito clara, de forma que não haja possibilidade de múltiplas interpretações, mantendo um entendimento equalizado em relação às responsabilidades de cada integrante da equipe. Desse modo, será possível garantir uma maior eficiência da equipe, diminuindo os desentendimentos e retrabalhos.

Segundo Carvalho e Rabechini (2005), muitos projetos requerem entregas que são impossíveis de serem desenvolvidas, pois dependem de competências que estão fora do âmbito do projeto. Nestes casos, os projetistas abrem mão de desenvolver produtos ou serviços no projeto e buscam, por meio de terceiros, mão de obra e bens para serem incorporados ao projeto - os assim chamados subcontratados.

É importante ressaltar que quando ocorre uma terceirização de trabalhos a serem desenvolvidos existe a necessidade de acompanhar esses terceiros em todos os aspectos de gestão, garantindo ao máximo a qualidade do produto final. De acordo com Silva (1999), o 
processo de terceirização de atividades traz como consequência uma degradação de determinados processos de gestão, pois muitas vezes é feita uma transferência da responsabilidade pela condução dos processos de planejamento, em um nível de detalhe incompatível com o grau de responsabilidade global transferida ao fornecedor, o que pode implicar em riscos nem sempre plenamente identificados.

É de responsabilidade do gestor do projeto orientar e conduzir os trabalhos a serem desenvolvidos por terceiros, pois as empresas ou consultores externos podem utilizar metodologias, processos e procedimentos diferentes dos exigidos pelo sistema de qualidade da organização.

\subsubsection{Gestão de Projetos, Coordenação de Projetos e Equipe Multidisciplinar}

De acordo com El-Reedy (2012), quando se fala em sucesso de um projeto, o que vem a mente é apenas o lucro em dinheiro, porém para se atingir esse sucesso é preciso focar na gestão de projetos, respondendo a três perguntas:

- Qual o prazo planejado e o prazo executado?

- Qual o orçamento inicial e o custo real?

- O desempenho do projeto está de acordo com as especificações exigidas?

Sendo assim, um gestor de projetos será considerado bem sucedido se conseguir atingir o objetivo do projeto e satisfazer todos os stakeholders. Portanto, ao mesmo tempo em que se preocupa com a satisfação dos envolvidos, o gestor do projeto deve perseguir suas metas para garantir a finalização do projeto no tempo e custo planejados.

O gestor de projetos inicia um projeto na expectativa de que, com o uso de uma combinação de recursos, pessoas qualificadas e métodos adequados, os resultados previstos podem ser alcançados. No entanto, muitos projetos atrasam, terminam acima do orçamento previsto ou não conseguem atingir os resultados esperados. Eventos inesperados desorganizam o cronograma e desencadeiam efeitos que intervém na capacidade do gestor para manter o projeto conforme planejado. É muito provável que o gestor poderá responder a esses acontecimentos na medida em que ocorrem, mas esse estilo de comportamento de liderança é 
improvável que seja bem sucedido, pois uma crise leva a outra. O gestor de projetos torna-se consumido por "apagar incêndios" e essas ações reativas geram apenas correções de curto prazo (BARBER; WARN, 2005). Clarke (2009) afirma, com base em evidências, que gestores de projeto que falharam parecem operar como um membro da equipe, ao invés de um líder, de um "visionário", atuam de uma forma altamente reativa, respondendo a situações em vez de antecipar problemas e estabelecer uma visão clara e coletiva deles. Portanto, é evidente a necessidade de atuação proativa do gestor de projeto, fazendo uso de estratégias planejadas para contornar possíveis problemas ou conflitos no âmbito do projeto. De acordo com Jugdev, et al. (2013), gestores de projeto necessitam de infinitas competências técnicas e interpessoais de forma a equilibrar as áreas de conhecimento do projeto, os fatores críticos de sucesso, stakeholders e as outras demandas ao longo do ciclo de vida do projeto.

Uma das questões fundamentais para o sucesso na atuação do gestor de projetos é a composição da equipe do projeto, de caráter multidisciplinar. A composição dessa equipe, assim como das competências agregadas por intermédio dos seus membros, poderá constituir um recurso valioso para a atuação dos gestores.

Para Fontenelle (2002), a equipe multidisciplinar deve ser formada desde as etapas iniciais do processo de projeto para integrar com sinergia as necessidades e os conhecimentos de todos os especialistas e agentes envolvidos, dando um novo enfoque ao modelo de gestão sequencial tradicional.

Historicamente, a multidisciplinaridade se amplia continuamente nos projetos de construção, aumentando com isso o grau de dificuldade para a sua gestão. As responsabilidades são distribuídas entre diversos especialistas, incumbidos de parcelas cada vez menores do todo, dependentes de informações de terceiros, cujas definições provocam interferências múltiplas. Sendo assim, o aumento do volume de produtos gerados (disciplinas de projeto), a elevação do fluxo de informações e a necessidade de maior integração e compatibilização entre os intervenientes, em prazos de desenvolvimento global cada vez mais reduzidos, implicam uma maior demanda e uma maior complexidade na gestão do processo de projeto (MELHADO et al., 2005). E pela multidisciplinaridade do processo, surge em decorrência a necessidade de criar uma orientação dos trabalhos de cada um dos especialistas, segundo um mesmo conjunto de diretrizes, com a priorização das tarefas de acordo com os objetivos gerais do projeto e baseada em critérios voltados à qualidade (MELHADO, 1994). 
Essa orientação dos trabalhos mencionada no texto acima pode ser interpretada como parte da coordenação de projetos, que vem sendo muito discutida por diversos autores. Segundo Nóbrega Júnior (2012), a coordenação é uma área complexa que tem se renovado constantemente. A concepção contemporânea de coordenação de projetos entende que os indivíduos precisam desenvolver uma ampla gama de habilidades e competências para serem eficazes no seu trabalho. Existe, portanto, um crescente reconhecimento da importância das pessoas, que se distancia paulatinamente do foco exclusivo do sistema de produção para uma abordagem mais flexível, criativa, dinâmica e mais ligada ao campo das ciências sociais e humanas.

Skulmosky e Hartman (2010) afirmam que a competência principal da liderança na fase de iniciação do projeto é a habilidade de se pronunciar com clareza. É necessário para os lideres que eles se pronunciem com clareza para se atingir o sucesso do projeto e isso é alcançado por meio da compreensão clara das ideias e objetivos dos clientes de tal maneira que seja possível desenvolver um bom plano de projeto.

Segundo Aquino e Melhado (2002), entre os fatores que afetam a qualidade do produto final na construção civil e, consequentemente, impactam o sucesso do projeto, pouca importância é dada ao estágio da concepção e ao desenvolvimento do projeto.

Segundo Csepcsényi, Salgado e Ribeiro (2006), o processo de desenvolvimento de projeto requer, do profissional responsável pela sua condução e liderança, capacidade de acompanhar as equipes na solução das incompatibilidades encontradas, de forma a buscar sempre a melhor solução possível. Para avaliar as dificuldades e tomar a decisão acertada - que muitas vezes pode implicar custo adicional para o empreendedor - será fundamental que o coordenador de projetos saiba levar o problema à equipe e buscar, junto aos especialistas de cada área do conhecimento envolvida, a melhor solução possível.

Melhado (1994) afirma que a coordenação de projetos é a atividade decorrente de um caráter multidisciplinar que deve ser exercida por profissional experiente, de forma imparcial e isenta, representando em primeiro plano os seguintes objetivos básicos: orientar a equipe de projeto e garantir o atendimento as necessidades dos clientes. Garantir a obtenção de projetos coerentes e completos, isto é, sem conflitos entre as especialidades e sem pontos de indefinição; coordenar o desenvolvimento do projeto, distribuindo tarefas e estabelecendo 
prazos, além de disciplinar o fluxo de informações entre os participantes e demais envolvidos no projeto, transmitindo dados e realizando consultas, organizando reuniões de integração e controlando a qualidade do "serviço de projeto", e decidir entre alternativas para a solução de problemas técnicos em especial nas interfaces entre especialidades.

De acordo com Otter e Emmitt (2008), o coordenador de projetos deve incentivar o uso de diálogos como forma de comunicação para que haja uma melhor compreensão das tarefas do projeto a serem executadas. A atuação da coordenação de projetos em relação à comunicação também é importante para compartilhar o conhecimento, alcançar o entendimento mútuo e facilitar a distribuição das informações entre a equipe e todos os envolvidos no projeto.

A proposta de Melhado (1994), exemplificada para o caso dos empreendimentos imobiliários, mostra claramente que a equipe multidisciplinar deve seguir orientações do coordenador de projeto e este, por sua vez, necessita seguir as necessidades do usuário, exigências de normas e diretrizes de projeto na empresa (Figura 9).

De maneira detalhada e com foco nos projetos realizados sob encomenda, Grilo (2002) apresenta uma proposta de estruturação da equipe de um projeto (Figura 10).

Em ambas as propostas, fica bem clara a posição e função do coordenador de projetos. A interface com o cliente e equipe de produção pode ser interpretada como algumas de suas funções, além de ser visível o papel de orientar a equipe, delegando tarefas e avaliando recursos necessários para realizar essas tarefas conforme exigências do cliente. Melhado (1994) afirma que fica claro o quanto é fundamental que o líder de um grupo seja crítico e flexível o suficiente para avaliar a produção do grupo multidisciplinar e decidir acerca da necessidade ou não de consultar especialistas externos a ele. 
Figura 9 - Proposta de estruturação para a equipe multidisciplinar envolvida no desenvolvimento do projeto

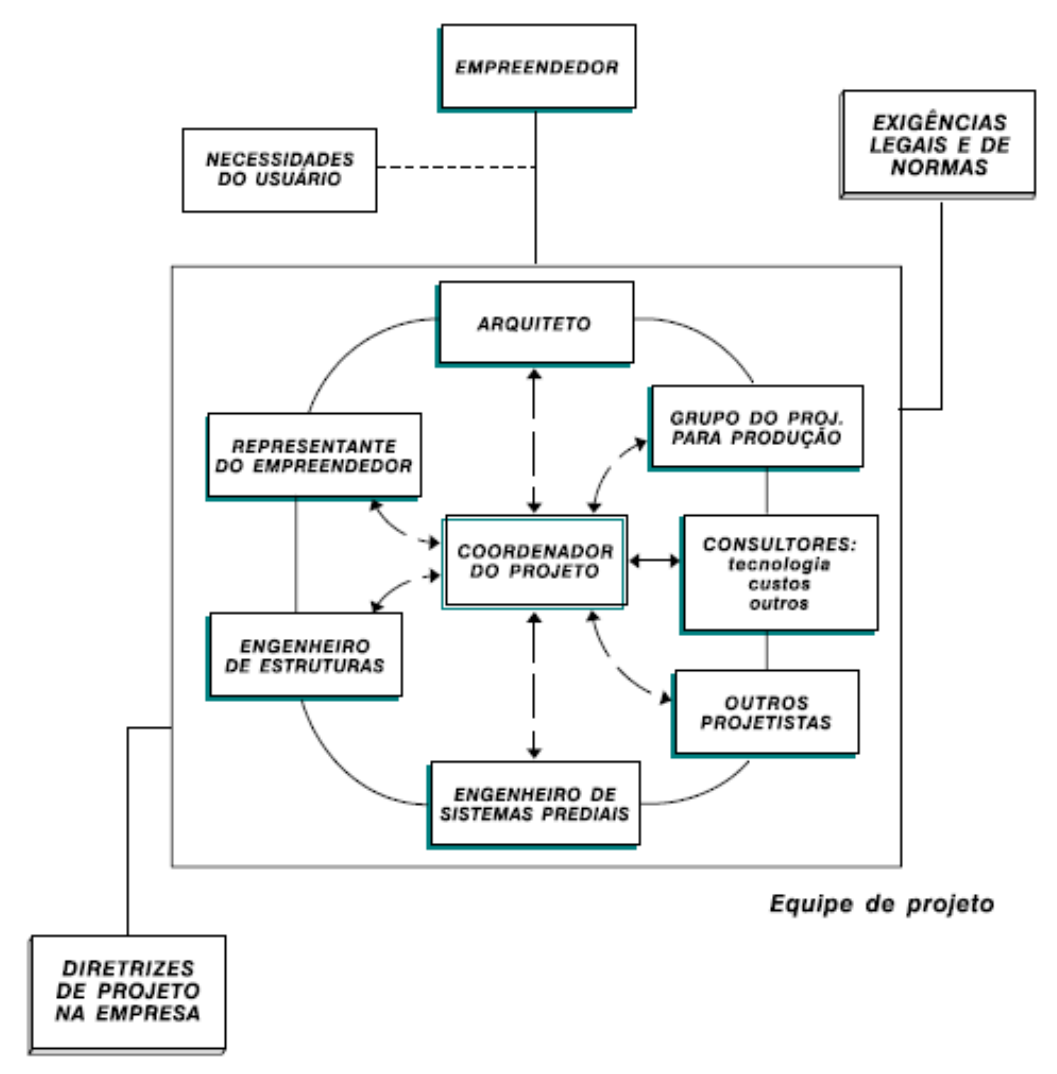

Fonte: Melhado (1994)

Adesse (2004) define líder como "a pessoa capaz de perceber as potencialidades de cada membro do grupo e de saber explorá-las de forma a trazer benefícios para o projeto em questão; é capaz de buscar o comprometimento e o aperfeiçoamento individual em prol do trabalho em grupo". O líder sempre buscará uma melhoria contínua que contribuirá em vários aspectos e para a equipe como um todo. "É um profissional capaz de motivar e fazer com que os profissionais de uma empresa ou de um grupo trabalhem não só com a razão, mas também com a emoção, despertando-lhes o prazer de trabalhar" (ADESSE; SALGADO, 2006). 
Figura 10 - A constituição da equipe do projeto

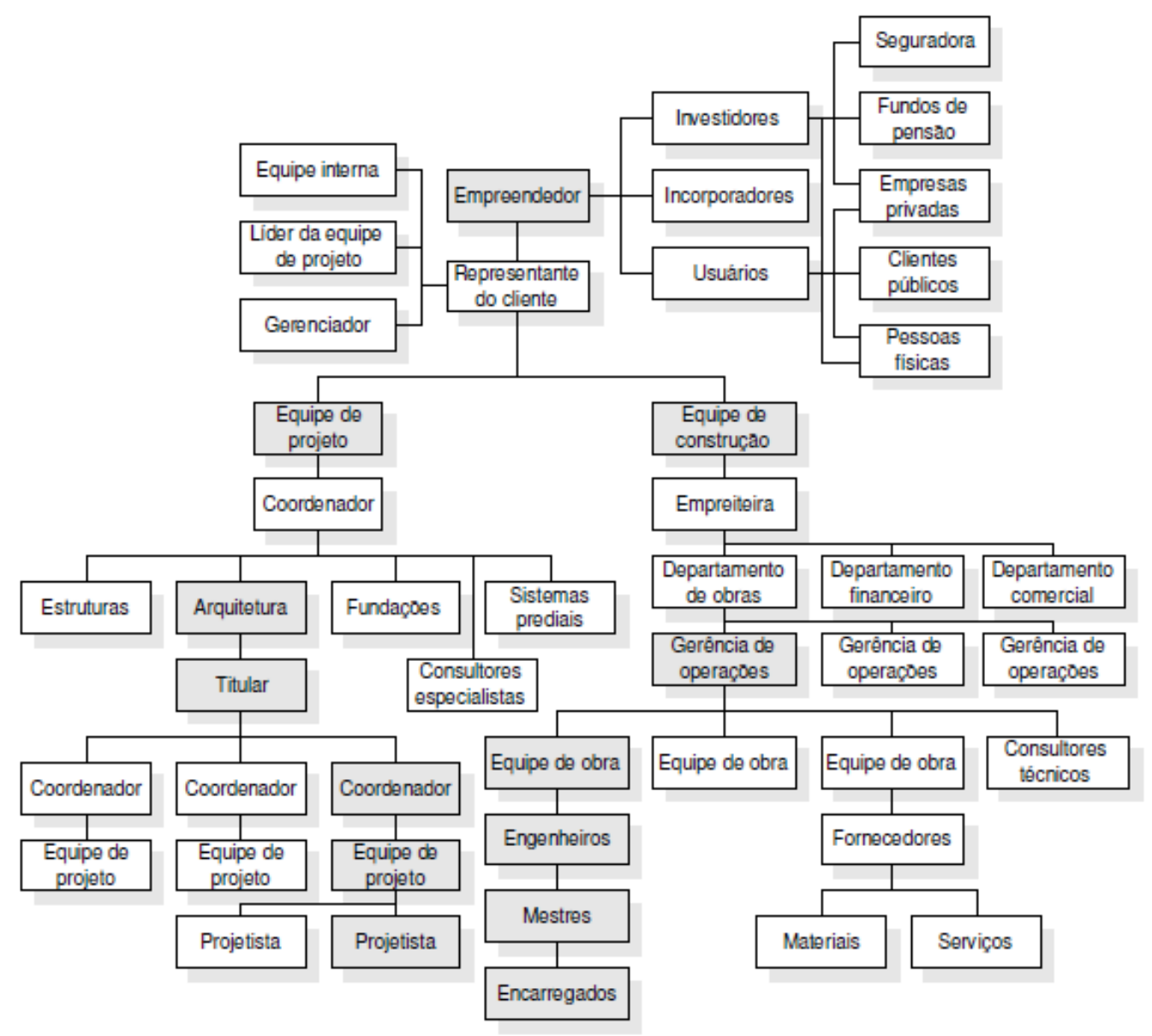

Fonte: Grilo (2002)

\subsubsection{BIM (Building Information Modeling)}

Os problemas atuais relacionados à gestão de projetos e a eficiência e qualidade da construção são motivos nítidos da necessidade de ações para melhorar um setor que permanece atrás de qualquer outro na tentativa de se tornar mais competitivo e proporcionar um melhor serviço para os clientes e à sociedade como um todo (ARANDA-MENA, et al, 2009). Segundo os autores, para reduzir disputas, compartilhar riscos e impulsionar a indústria no uso de uma nova documentação de edifício, deve-se adotar a tecnologia de modelagem de informação da construção (BIM). 
Building Information Modeling consiste em informações que representam todo edifício e o completo conjunto de documentos do projeto armazenados em um banco de dados integrado. Toda a informação é paramétrica, e dessa forma interconectada (WONG; FAN, 2013).

Segundo Bazjanac (2004), BIM consiste em gerar um modelo do conjunto de dados multidisciplinares e que descreve toda a informação pertinente ao edifício em particular de uma forma precisa. É uma representação virtual dos dados que definem o projeto do ponto de vista multidisciplinar.

De acordo com Mathews (2013), o termo BIM tem um significado amplo e extenso que abrange tecnologias e metodologias em torno da criação e coordenação de dados digitais de um edifício, que é representado visualmente em três dimensões (3D).

A escolha da modelagem da informação da construção como alternativa para os modelos de representação do projeto é justificada por sua abordagem sistêmica e integrada de todas as fases do ciclo de vida, apresentadas em um modelo único e compartilhado das informações, levando a melhores resultados e a menos interferências entre a produção e as informações utilizadas pelos diversos agentes envolvidos no processo (ABAURRE, 2013).

De acordo com Underwood e Isikdag (2011), embora o principal papel do BIM seja reconhecido como um facilitador da fase de "design" de um empreendimento, BIM pode ter uma ampla gama de funções como a conexão interior e exterior de espaços urbanos, facilitando o compartilhamento de informações entre os vários stakeholders. As aplicações dos softwares utilizados permitem o uso e a gestão das informações compartilhadas, facilitando as simulações dos processos de construção e apoiando as ações de resposta a emergências.

Por se tratar de um banco de dados único para o desenvolvimento de um projeto, o sistema BIM permite a execução de alterações dinâmicas na modelagem gráfica que se refletem de uma maneira positiva, pois essas alterações podem ser visualizadas em tempo real por todas as áreas técnicas envolvidas.

Quaisquer alterações feitas a um objeto dentro do modelo automaticamente afeta as montagens relacionadas, pois o modelo pode conter todas as informações necessárias 
interligadas. É bem diferente da representação 2D dos projetos convencionais em CAD. Por essas razões, BIM já começou mudando a forma como os projetistas colaboram com os consultores e construtores, e ele também tem a capacidade de orientar todos os agentes para a fase de execução, antecipando questões relativas à produção dos edifícios (WONG; FAN, 2013). Dessa forma, ao agregar mais informações associadas aos objetos, como tempo e custos, a modelagem da construção passa a ser considerada, além do que seria simplesmente uma representação em 3D, como sendo 4D, 5D... nD.

Dentre vários benefícios e vantagens que o BIM pode vir a oferecer, destacam-se o aumento de produtividade, melhoria da qualidade nas apresentações gráficas, melhoria da comunicação interdisciplinar, diminuição da redundância de dados, retrabalhos e erros, entre outros. No entanto, a implementação da estratégia de BIM possui um longo caminho a percorrer até atingir maturidade, e vem sendo continuamente aprimorado (UNDERWOOD; ISIKDAG, 2011).

Os sistemas de BIM podem contribuir para a qualidade e clareza da geração de informações dos desenhos e, se utilizados de modo colaborativo por toda a equipe de projetos, resultarão em benefícios para todos os envolvidos. De acordo com Mathews (2013), há uma crescente demanda por uma colaboração mais intensa dentro do ambiente construído e um incentivador para trazer essa mudança é a plataforma fornecida pelas tecnologias BIM e as oportunidades de colaboração em projetos que ela promove.

A utilização da tecnologia BIM nas empresas de projetos vem beneficiando o processo de projeto. Porém, a cultura das empresas do setor, a informalidade do fluxo das informações e documentos entre os agentes envolvidos, o uso de ferramentas inadequadas de TI e a falta de preparo dos projetistas para as novas ferramentas de TI, afetam o processo de projetos e consequentemente a qualidade dos projetos (ITO, 2007).

Um dos aspectos mais importantes do BIM é a sua característica de troca de informações entre as partes colaborativas. Isto, naturalmente, envolve a troca de informações entre diferentes sistemas ou plataformas. O problema é que os sistemas utilizados não são naturalmente desenvolvidos por uma única parte - um grande número de soluções de software, desenvolvidos por diferentes produtores deveriam ser capazes de "falar a mesma língua". Tradicionalmente, os produtores de software têm desenvolvido seus próprios 
formatos de arquivo, mais ou menos sem se preocupar com a possibilidade de utilizá-lo em outros sistemas de software. O grau limitado de interoperabilidade é uma das barreiras mais importantes para a implementação do BIM e para a utilização das tecnologias da informação e comunicação como uma atividade colaborativa (JENSEN; JÓHANNESSON, 2013).

Khosrowshahi e Arayici (2012) descreveram o uso de BIM em termos de nível de maturidade de utilização. Os estágios de maturidade, que fornecem uma estrutura sistemática para a classificação da implementação de BIM, são descritos resumidamente a seguir.

Pré-BIM - refere-se à prática de construção tradicional que engloba significativas barreiras e ineficiências. Por exemplo, muitas informações do projeto são armazenadas em papel, como desenhos e documentos escritos, o que é fácil de perder e causar danos. Milhares de documentos são compartilhados durante um projeto, causando erros humanos significativos no uso e controle de versões. Um processo pobre de gestão de informação leva à compreensão incompleta do projeto, ineficiências funcionais, trabalho impreciso ou confrontos entre os componentes. Além disso, as lições aprendidas não são bem organizadas e nem mostradas em detalhe.

BIM Fase 1 - refere-se à migração de 2D para 3D e à modelagem e documentação baseadas em objetos. O modelo BIM é feito de elementos arquitetônicos reais que são representados corretamente em todas as vistas. O modelo BIM ainda é uma disciplina individual e os entregáveis são, em sua maioria, em CAD.

BIM Fase 2 - progride da modelagem para colaboração e interoperabilidade. Projetar e realizar a gestão de um edifício é um processo altamente complexo, que exige uma comunicação fluida e colaboração entre todos os membros da equipe do projeto. A maturidade da Fase 2 requer comunicação integrada e compartilhamento de dados entre os stakeholders para apoiar essa abordagem colaborativa.

BIM Fase 3 - essa etapa é a transição da colaboração para a integração e reflete a real filosofia BIM. Nesse estágio, as fases do ciclo de vida do projeto se desfazem substancialmente e os agentes interagem em tempo real para gerar benefícios consistentes em fluxos de trabalho cada vez mais virtuais. O modelo da Fase 3 se torna interdisciplinar, permitindo análises complexas em estágios iniciais de projeto. Nesse estágio, as entregas do 
modelo se estendem além de propriedades de objetos semânticos para incluir inteligência de negócios e princípios de lean construction.

A utilização do sistema BIM exige uma nova forma de pensar. Profissionais habituados a desenvolver projetos utilizando metodologias e processos tradicionais aplicados à plataforma $2 \mathrm{D}$ veem a necessidade de alterar seus conceitos quando da utilização da tecnologia BIM. As equipes que tradicionalmente eram fragmentadas e controladas se tornam uma equipe única integrada e colaborativa.

A implementação do BIM em uma perspectiva de longo prazo mudará não só as práticas de trabalho, mas também as relações contratuais entre os agentes (MANZIONE, 2013). O autor afirma que graças à tecnologia envolvida na construção do modelo BIM, é possível o trabalho colaborativo com os diversos agentes; porém, é exigido um elevado grau de maturidade para se chegar a essa fase, que, além da mudança na prática, deverá requerer mudanças das relações contratuais para um novo objetivo.

Uma efetiva e positiva utilização do sistema BIM exige inúmeras modificações como, por exemplo: alterações contratuais, de escopos de serviços e formatos de resultados, mudança no ambiente de trabalho buscando a integração das equipes multidisciplinares e foco no desempenho da equipe como um todo e não individual de cada disciplina, alteração no processo de projeto, na comunicação; entre outras. Essas modificações normalmente são vistas com resistência pelos profissionais, principalmente por projetistas, e isso pode contribuir para a dificuldade da implementação de BIM em uma organização.

De acordo com Jensen e Jóhannesson (2013), o mais importante no processo de implementação parece ser a condução da transformação em pequenos passos. A parte de recursos humanos da transformação para o "pensamento em BIM" pode ser uma parte muito difícil. É natural que alguns funcionários sintam que estão sendo ameaçados pelas mudanças. Isso por si só pode ser visto como uma boa razão para as empresas implementarem o BIM em pequenos passos. Os resultados obtidos por meio da pesquisa realizada pelos autores mostram a importância do envolvimento do gestor de projeto na implementação BIM, pois afirmam que a liderança deve estar convicta dos benefícios do BIM, que deve ser visto como elemento principal do negócio e não apenas como mais um sistema de software. Caso contrário, será difícil obter recursos suficientes atribuídos ao processo de transformação. Se uma empresa 
quer implementar o sistema BIM nos processos de projeto e decisão, isso significa que mudanças fundamentais são necessárias nos processos de trabalho. O período de transição dos métodos de trabalhos tradicionais para os processos baseados em BIM é um período crítico para todas as empresas e tem que ser executado com atenção aos interesses próprios de cada

organização. É necessário difundir o conhecimento para os colaboradores da empresa, de modo a torná-los conscientes dos potenciais desses novos processos e atividades. Plena aceitação, participação e exploração das possibilidades não terão oportunidade até que isso ocorra.

\subsection{CONTRATAÇÃO DE PROJETOS}

O aumento da complexidade técnica e gerencial da construção de edifícios tem impulsionado a introdução de novas formas de contratação e organização ao redor do mundo. Sistemas contratuais inovadores permitem maior eficiência e eficácia na construção, favorecendo o estabelecimento de relações harmoniosas entre projetistas, construtores e clientes (GRILO; MELHADO, 2002).

O processo de contratação tem o propósito de estabelecer a correta relação entre as partes compradora e vendedora, que celebram contrato com a finalidade de executar um empreendimento de engenharia, e também deve considerar interesses de outros agentes envolvidos. O ciclo inicia-se com a assinatura do contrato entre o comprador e o vendedor, termina com a sua liquidação e compõe-se de todas as ações envolvidas com a entrega e aceitação de obras e serviços. A finalidade dessas ações é assegurar que o contrato seja executado conforme os seus termos. Para ser eficiente, o processo de administração de contratos requer planejamento, que deve ser feito antes da assinatura do contrato, em paralelo com a análise do risco de execução do projeto que se deseja contratar (RICARDINO; SILVA; ALENCAR, 2008).

Os sistemas contratuais exercem uma notável influência na gestão de projetos, na medida em que definem as relações contratuais e funcionais entre os agentes. Sistemas contratuais inadequados podem conduzir a acréscimos nos custos e atrasos, reivindicações e disputas, bem como perda da qualidade do investimento nos empreendimentos (GRILO; MELHADO, 2002). 
O cliente normalmente realiza uma análise de vários fatores para determinar o tipo de contrato a ser adotado. Dentre esses fatores destacam-se: a complexidade do empreendimento, características do cliente, riscos, prazos, exigências em relação à alocação de recursos, entre outros.

De acordo com Ricardino, Silva e Alencar (2008), em relação à modalidade de pagamento, os contratos podem ser subdivididos em:

Preço Global (ou Fixo): o objeto é contratado por um valor total, e os serviços são remunerados por etapa alcançada. O risco maior é da parte contratada, que é responsável pelo preço e pelos quantitativos de serviços. Exige completa e detalhada especificação técnica do objeto do contrato. Este regime é utilizado na maioria das licitações e contratações de projetos do setor da construção pesada no Brasil, promovidos tanto pelo Poder Público como pela iniciativa privada.

- Potencialidades do regime: minimiza o acompanhamento do contrato pela contratante; tende a predispor favoravelmente a contratante à execução do projeto.

- Limitações do regime: favorece alterações contratuais pela contratante; favorece a perda da qualidade pela contratada, em favor da redução dos custos; induz a contratante à solução de controvérsias por arbitragem.

Preço Unitário: regime utilizado quando o objeto do contrato é bem conhecido, mas há indefinições nas quantidades de serviços. A contratada não é responsável pelos quantitativos. O risco tende a ser desfavorável à contratante. A remuneração é obtida pela multiplicação das quantidades executadas de cada serviço, pelo seu respectivo preço unitário.

- Potencialidades do regime: flexibilidade de atuação entre as partes contratante e contratada; permite início e término rápidos; há facilidade de acompanhamento.

- Limitações do regime: não há incentivo financeiro para a redução de prazos e do custo total do projeto; não garante necessariamente a qualidade dos serviços executados.

Administração: regime utilizado quando o objeto do contrato encontra-se caracterizado, mas os serviços que o compõem são de difícil quantificação. O risco é quase todo da parte 
contratante, que arca com todos os gastos. A contratada é remunerada pela aplicação de uma taxa incidente sobre todos os gastos necessários ao cumprimento do contrato.

- Potencialidades do regime: permite o máximo de flexibilidade entre as partes; minimiza conflitos futuros; permite à contratante selecionar e contratar com a empresa melhor qualificada.

- Limitações do regime: não assegura a contratante o custo final; exige constante controle da parte contratante; não incentiva a minimização de prazos e custos.

Metas ou alvos: regime às vezes também denominado de "aliança". Utilizado nos casos de contratação direta pela contratante. As partes elaboram em conjunto o orçamento que determina o valor contratado, bem como o prazo e/ou o valor de alguns dos serviços ("alvos") a serem acompanhados, vinculando a eles condições especiais de remuneração, por meio de cláusulas de ônus e de bônus. Os alvos podem ser somente de preço, ou de prazo, ou de preço e prazo.

- Potencialidades do regime: possibilita equilíbrio entre prazo, qualidade e custo, sem transferir integralmente os riscos à contratada; incentiva a melhoria do desempenho geral da contratada.

- Limitação do regime: não assegura à contratante o custo final do projeto.

\subsection{ESTRUTURA ORGANIZACIONAL}

A estrutura organizacional representa a forma como são agrupados e coordenados os recursos (humanos, físicos e financeiros) empregados nos diversos processos desenvolvidos na organização, com o intuito de se atingirem seus objetivos (VIVANCOS; CARDOSO, 2001).

De acordo com Valle et al. (2007), a configuração organizacional é elemento fundamental para o alcance dos objetivos empresariais, possibilitando a diferenciação e estrutura das atividades, por meio do seu agrupamento, por afinidade, em órgãos (diretorias, departamentos, divisões...) que espelham a forma considerada pela empresa como a mais viável para cumprir sua tarefa empresarial, diferenciados em importância e autonomia por 
meio do seu posicionamento em níveis hierárquicos e também possibilita a determinação dos mecanismos de autoridade e decisão.

Durante os últimos trinta anos uma revolução vem ocorrendo na introdução e desenvolvimento de novas estruturas organizacionais. Os executivos perceberam que as organizações devem ser mais dinâmicas, ou seja, elas devem ser capazes de se reestruturar rapidamente conforme as necessidades do mercado (KERZNER, 2009). De acordo com Bouer e Carvalho (2005), a estrutura organizacional é um fator crítico de sucesso para a implementação de uma estratégia de gestão. Portanto, o arranjo organizacional fornece elementos para a inferência sobre os principais direcionadores dessa estratégia.

Para Hao, Kasper e Muehlbacher (2012) a estrutura organizacional inclui a natureza dos níveis de hierarquia, a centralização de autoridade e integração horizontal. É uma construção multidimensional em que compreende:

- divisão de trabalho, especialmente papéis ou responsabilidades incluindo especialização, diferenciação, departamentalização, centralização ou descentralização e complexidade;

- mecanismos de comunicação ou coordenação incluindo normalização, formalização e flexibilidade.

A configuração da estrutura organizacional impede ou facilita a capacidade da empresa a se adaptar a mudanças, aprendizados, inovação para aprimorar sua capacidade de gerar valor adicional aos seus clientes. A estrutura organizacional também desempenha um papel fundamental na capacidade da empresa de identificar os recursos necessários, e a aquisição de novos conhecimentos, integrando-os à organização e reconhecendo sua capacidade de absorção (MARTÍNEZ-LEÓN; MARÍNEZ-GARCÍA, 2011).

Por meio do exame das necessidades em segmentação e integração de esforços, é possível entender o quadro de alternativas estruturais que se configura e que contempla as formas mais tradicionais de organização, como as hierárquicas e as matriciais. No entanto, com a intensificação das atividades de projetos nas empresas observadas no início do século XXI, novas preocupações se apresentam na análise das formas organizacionais. A busca nas empresas por estruturas inovadoras que apresentem baixo nível de formalização e possibilitem 
multiplicidade de comando, diversificação elevada e comunicação horizontal e diagonal, tem sido frequente entre as empresas que precisam articular as atividades rotineiras e não rotineiras (RABECHINI Júnior et al., 2011).

A estrutura funcional coloca o projeto a ser executado dentro de um dos departamentos técnicos da empresa. Com isso o responsável pelo projeto passa a ser o gerente funcional deste departamento. Como alternativas à rigidez da estrutura organizacional funcional ou tradicional surgiram as estruturas projetizada e matricial. A estrutura matricial, que é uma combinação da funcional e da projetizada, ainda pode ser dividida em matricial fraca, equilibrada e forte (PATAH; CARVALHO, 2002).

Para Vasconcellos e Hemsley (2002), o conceito de estrutura matricial leva em conta o exame da necessidade de utilização de duas ou mais formas de estrutura simultaneamente sobre os mesmos membros de uma organização. A estrutura matricial busca distribuir o projeto ao longo das divisões da empresa e, com isso, utilizar melhor a capacidade técnica disponível, o que não ocorre numa estrutura por projetos. Os custos são diminuídos em função da maior racionalidade no uso dos recursos e do compartilhamento da autoridade e da responsabilidade entre o gerente funcional e o gerente do projeto.

Em inúmeras organizações, ao se adotar a estrutura matricial, surgem conflitos entre o gerente do projeto e o gerente funcional, quando não há uma negociação bem estruturada e desenvolvida, pois podem surgir comandos duplos a um mesmo recurso. Portanto, para esse tipo de estrutura é preciso definir bem os papéis de liderança de modo a não prejudicar os objetivos do projeto e nem gerar desgastes na equipe.

Em relação à estrutura projetizada, a maior vantagem é que um único indivíduo, o gerente do projeto, mantém uma autoridade completa sobre o projeto como um todo. No entanto, este tipo de estrutura cria uma divisão dentro da empresa (KERZNER, 2009).

Não há uma estrutura organizacional que seja solução única para as organizações ou mesmo para todos os projetos. É preciso realizar uma análise de forma a determinar qual tipo seria mais adequado para cada caso. Kerzner (2009) levantou os seguintes fatores que, segundo ele, influenciam a escolha da estrutura organizacional de um projeto: tamanho do projeto, duração do projeto, experiência da organização na gestão de projetos, filosofia da alta gestão da 
empresa quanto à gestão de projetos, localização física do projeto, recursos disponíveis e aspectos específicos do projeto. O autor enfatiza que não há boa ou má estrutura organizacional, há apenas as estruturas organizacionais apropriadas ou não para cada caso.

\subsubsection{Estrutura Funcional}

A organização funcional é uma hierarquia em que cada funcionário possui um superior bem definido. No nível superior, os funcionários são agrupados por especialidade, como produção, marketing, engenharia e contabilidade. Cada departamento em uma organização funcional executa o seu trabalho do projeto de modo independente dos outros departamentos (PMI, 2010); ver Figura 11. As vantagens e desvantagens desse tipo de estrutura para projetos estão no Quadro 1.

Figura 11 - Organização Funcional

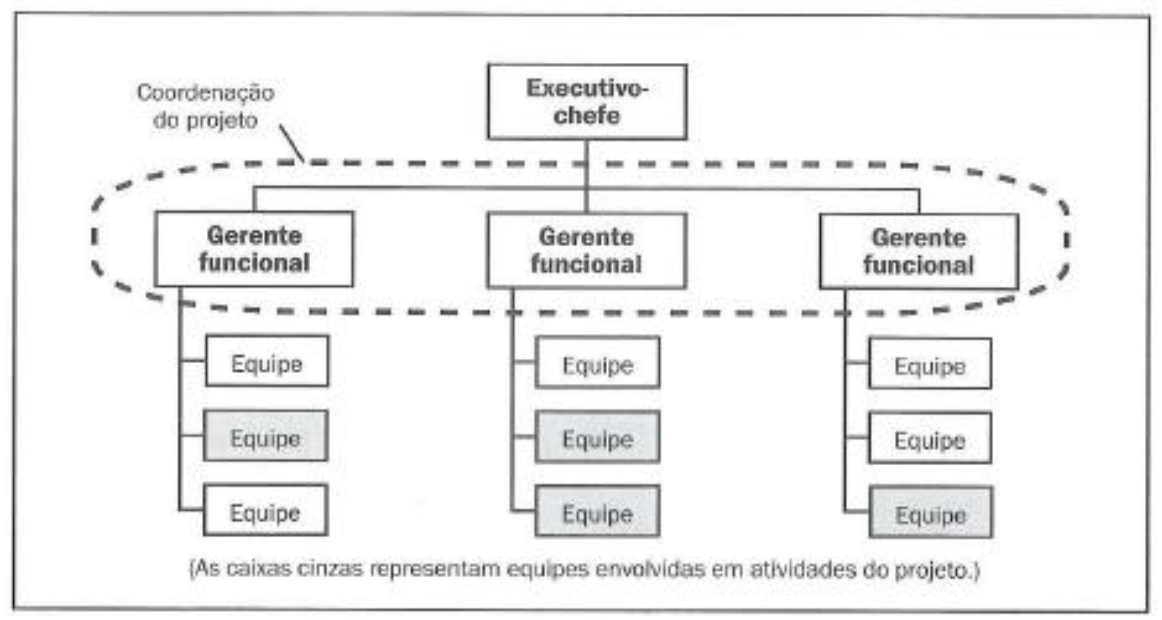

Fonte: PMI (2010) 
Quadro 1 - Vantagens e Desvantagens da Estrutura Funcional

\begin{tabular}{|c|c|}
\hline Vantagens & Desvantagens \\
\hline $\begin{array}{l}\text { - existe uma grande flexibilidade no uso dos } \\
\text { recursos humanos necessários ao projeto; } \\
\text { - especialistas em determinado assunto podem ser } \\
\text { utilizados em diferentes projetos; } \\
\text { - os especialistas de um mesmo departamento } \\
\text { podem ser facilmente reunidos para compartilhar } \\
\text { conhecimentos e experiências; } \\
\text { - o departamento funcional é a base para a } \\
\text { continuidade do conhecimento tecnologico, quando } \\
\text { um individuo deixa o projeto ou mesmo a empresa; } \\
\text { - o departamento funcional proporciona um } \\
\text { caminho natural para o crescimento dos individuos } \\
\text { cuja especialidade está na área funcional. }\end{array}$ & $\begin{array}{l}\text { - O cliente não é o foco das atividades do } \\
\text { departamento que gerencia o projeto; } \\
\text { - o departamento funcional tende a ser orientado } \\
\text { em direção às suas atividades particulares; } \\
\text { - a responsabilidade total do projeto não é } \\
\text { delegada a nenhum funcionário em especifico; } \\
\text { - as respostas às necessidades dos clientes são } \\
\text { lentas; } \\
\text { - existe uma tendência de subestimar o projeto; } \\
\text { - a motivação das pessoas alocadas no } \\
\text { gerenciamento do projeto tende a ser pequena em } \\
\text { relação ao mesmo; } \\
\text { - este tipo de estrutura organizacional não facilita } \\
\text { uma abordagem holistica em relação ao projeto. }\end{array}$ \\
\hline
\end{tabular}

Fonte: Patah; Carvalho (2002)

\subsubsection{Estrutura Matricial}

As organizações matriciais são uma combinação de características das organizações funcionais e projetizadas. As matrizes fracas mantêm muitas das características de uma organização funcional e o papel do gerente de projetos é mais parecido com a de um coordenador ou facilitador do que com o de um gerente de projetos propriamente dito (ver Figura 12). As matrizes fortes (Figura 13) possuem muitas das características da organização projetizada e podem ter gerentes de projetos em tempo integral com autoridade considerável e pessoal administrativo trabalhando para o projeto em tempo integral. Enquanto a organização matricial balanceada reconhece a necessidade de um gerente de projetos, ela não fornece a ele autoridade total sobre o projeto (PMI, 2010); ver Figura 14. As vantagens e desvantagens desse tipo de estrutura para projetos estão no Quadro 2. 
Figura 12 - Organização Matricial Fraca

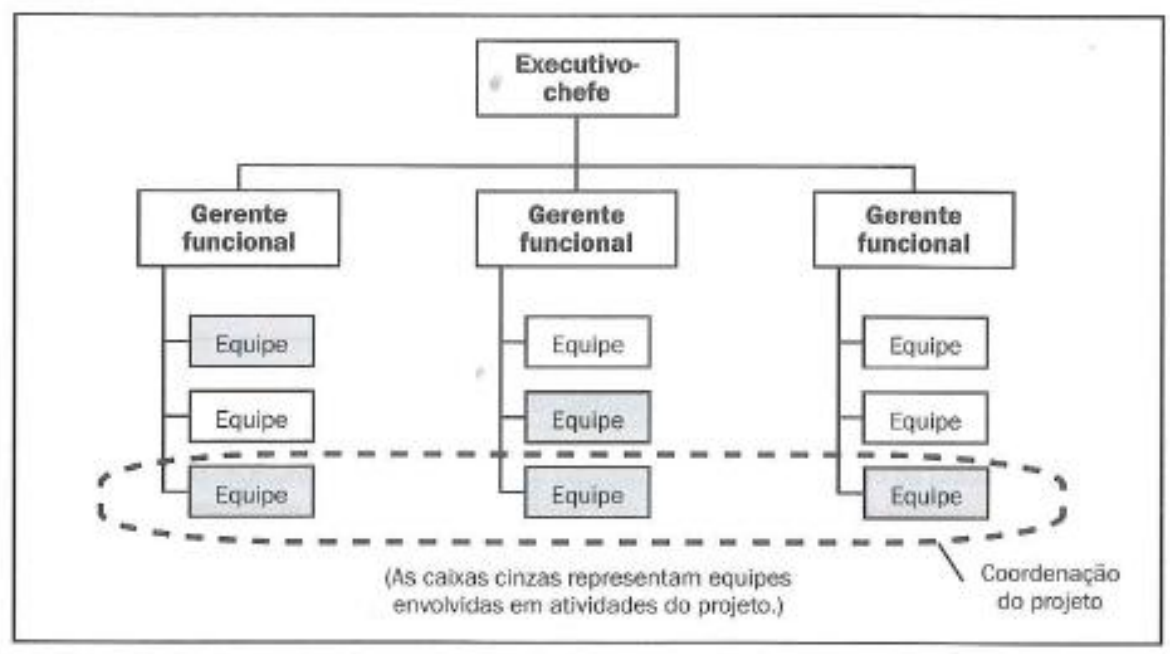

Fonte: PMI (2010)

Quadro 2 - Vantagens e Desvantagens da Estrutura Matricial

\begin{tabular}{|c|c|}
\hline & Desvantagens \\
\hline $\begin{array}{l}\text { - existe um responsável pelo projeto como um } \\
\text { todo: o gerente do projeto; } \\
\text { - devido ao fato do projeto estar distribuido ao } \\
\text { longo das divisões da empresa, ele pode utilizar toda } \\
\text { a capacidade técnica da mesma; } \\
\text { - existe uma ansiedade menor sobre o que irá } \\
\text { ocorrer com as pessoas envolvidas com o projeto, ao } \\
\text { fim do mesmo; } \\
\text { - as respostas às necessidades dos clientes são } \\
\text { rápidas; } \\
\text { - a estrutura matricial é flexível; } \\
\text { - o projeto possui representantes das unidades } \\
\text { administrativas da empresa; } \\
\text { - devido ao fato de, normalmente, ocorrerem } \\
\text { vários projetos simultaneamente nas empresas, a } \\
\text { estrutura matricial permite uma maior otimização do } \\
\text { uso dos recursos da empresa. }\end{array}$ & $\begin{array}{l}\text { - podem existir dúvidas quanto à responsabilidade } \\
\text { pela tomada de uma decisão dentro do projeto, isto } \\
\text { pode atrasar a realização do mesmo; } \\
\text { - os diferentes gerentes de projeto podem } \\
\text { "competir" pelos recursos técnicos disponiveis na } \\
\text { empresa, fazendo com que o uso dos mesmos deixe } \\
\text { de ser realizado da melhor maneira possivel; } \\
\text { - em estruturas matriciais fortes, o problema do } \\
\text { atraso na conclusão do projeto é tão grave quanto na } \\
\text { estrutura projetizada; } \\
\text { - é necessário que o gerente de projetos possua } \\
\text { uma habilidade especial em negociar recursos com os } \\
\text { gerentes funcionais; } \\
\text { - a estrutura matricial viola o princípio de } \\
\text { gerenciamento da unidade de comando: os } \\
\text { funcionários da empresa possuem dois chefes, o } \\
\text { gerente do projeto e o gerente funcional. }\end{array}$ \\
\hline
\end{tabular}

Fonte: Patah \& Carvalho, 2002. 
Figura 13 - Organização Matricial Forte

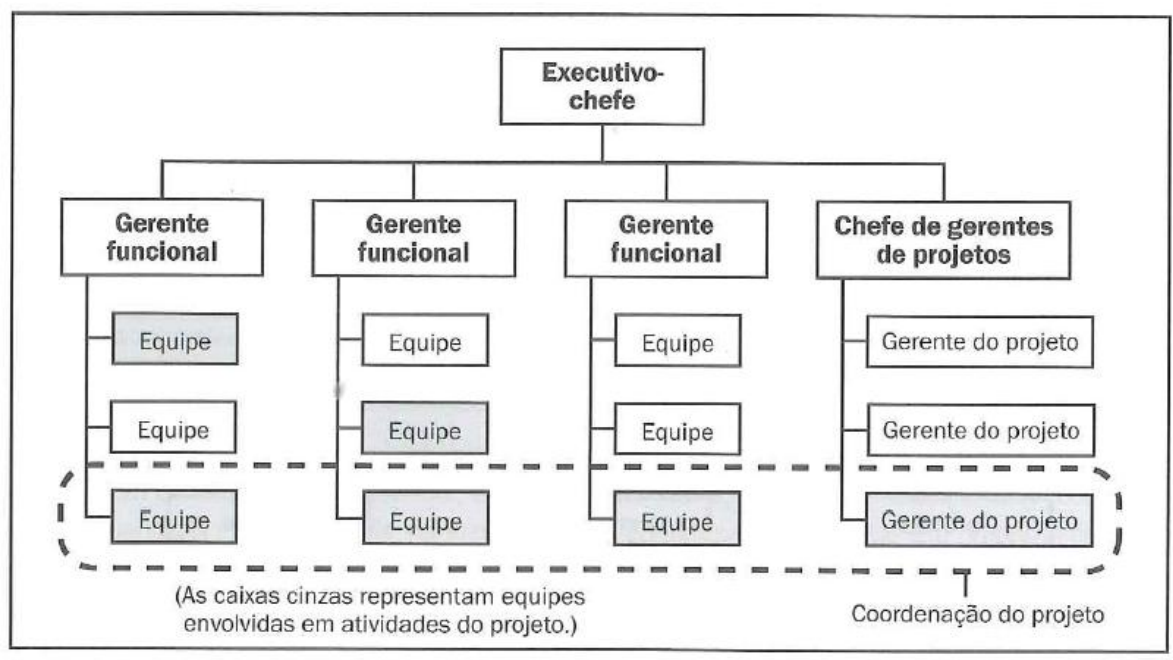

Fonte: PMI (2010)

Figura 14 - Organização Matricial Balanceada

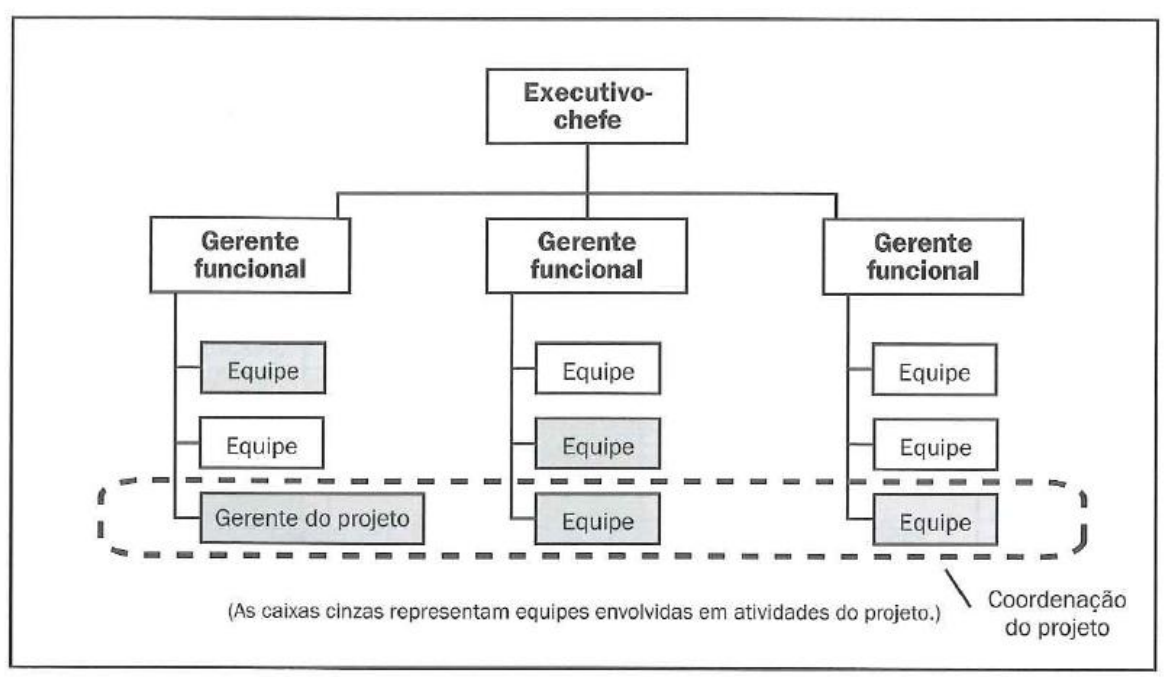

Fonte: PMI (2010) 


\subsubsection{Estrutura Projetizada}

Em uma organização projetizada, os membros da equipe normalmente trabalham no mesmo ambiente e os gerentes de projetos possuem grande independência e autoridade. As organizações projetizadas, em geral, possuem como unidades organizações denominadas departamentos, mas esses grupos se reportam diretamente ao gerente do projeto ou oferecem serviço de suporte aos vários projetos (Figura 15). As vantagens e desvantagens desse tipo de estrutura para projetos estão no Quadro 3.

Figura 15 - Organização Projetizada

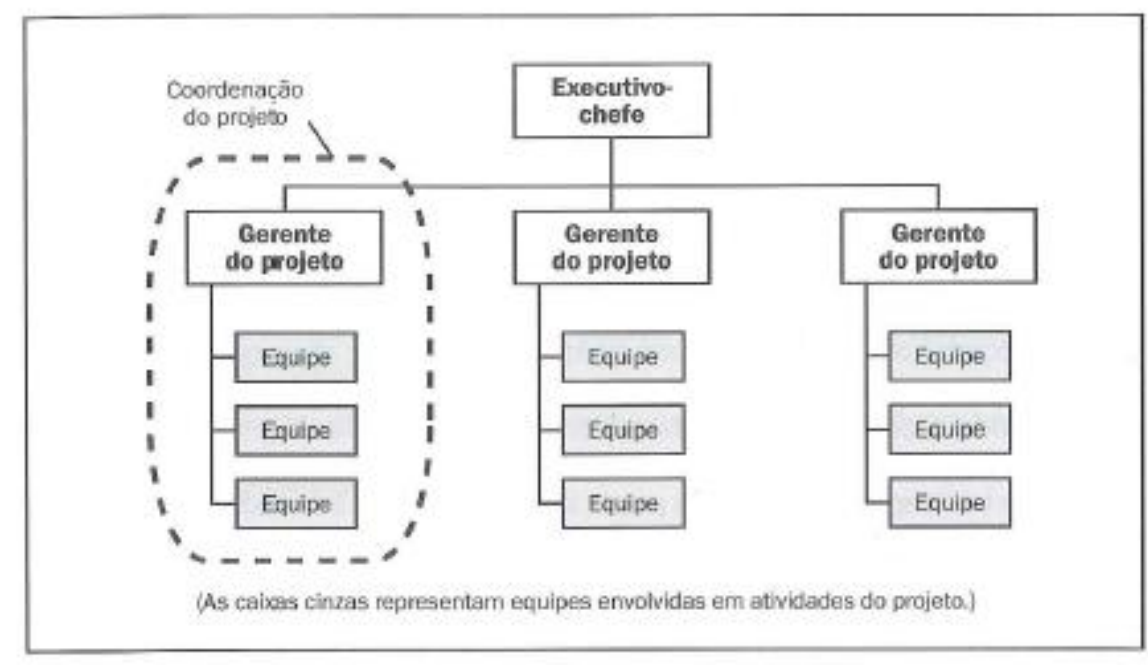

Fonte: PMI (2010) 
Quadro 3 - Vantagens e Desvantagens da Estrutura Projetizada

\begin{tabular}{|c|c|}
\hline Vantagens & Desvantagens \\
\hline $\begin{array}{l}\text { - gerente de projeto tem total autoridade sobre o } \\
\text { projeto; } \\
\text { - todos os membros do projeto encontram-se sob a } \\
\text { responsabilidade do gerente do projeto; } \\
\text { - as comunicações são facilitadas em comparação } \\
\text { à estrutura funcional; } \\
\text { - os membros do time do projeto possuem uma } \\
\text { forte identidade própria e, com isso, tendem a } \\
\text { desenvolver um alto nivel de comprometimento com } \\
\text { o projeto; } \\
\text { - a possibilidade de se tomar decisões rápidas é } \\
\text { maior; } \\
\text { - existe uma unidade de comando dentro do } \\
\text { projeto; } \\
\text { - estruturas projetizadas são estruturalmente } \\
\text { simples e flexiveis, e relativamente fáceis de se } \\
\text { compreender e implementar; } \\
\text { - a estrutura organizacional tende a permitir uma } \\
\text { abordagem holistica ao projeto. }\end{array}$ & $\begin{array}{l}\text { - quando a organização tem vários projetos, é } \\
\text { comum que vários novos grupos sejam criados, isto } \\
\text { pode ocasionar duplicidade de trabalho; } \\
\text { - as pessoas com conhecimentos especificos sobre } \\
\text { determinados assuntos tendem a serem alocadas aos } \\
\text { projetos quando elas estão disponiveis e não quando } \\
\text { elas são necessárias para o projeto; } \\
\text { - para projetos de alta tecnologia, o fato dos } \\
\text { especialistas "pertencerem" aos setores funcionais é } \\
\text { um grande problema para o gerente de projetos, pois } \\
\text { ele precisa do trabalho destes especialistas } \\
\text { constantemente; } \\
\text { - estruturas projetizadas tendem a apresentar uma } \\
\text { certa inconsistência na maneira pela qual as politicas } \\
\text { e procedimentos internos da empresa são cumpridos; } \\
\text { - existe uma considerável incerteza sobre o que irá } \\
\text { ocorrer com os membros da equipe do projeto quando } \\
\text { o mesmo terminar. }\end{array}$ \\
\hline
\end{tabular}

Fonte: Patah \& Carvalho, 2002.

\subsection{GESTÃO DA INFORMAÇÃO E COMUNICAÇÃO}

Uma mudança notável vem ocorrendo no processo de projeto na área da engenharia, mais precisamente na área de projetos. Sob a influência das ciências sociais, o processo de projeto, que foi centrado por anos apenas nos usuários, possui agora a tendência em focar mais na experiência participativa. Esta mudança de perspectiva está baseada na mudança de projeto PARA usuários para projetos COM usuários, em que novas formas de pensar e trabalhar são exigidos. Projeto participativo pode ser definido como uma atitude em que todos os agentes envolvidos no processo de projeto podem colaborar (BALLEJOS; MONTAGNA, 2010).

As atividades relacionadas ao planejamento, execução, monitoramento e encerramento de um projeto são dependentes de informações que devem ser disponibilizadas no tempo da demanda (FAGUNDES et al., 2005). No início do projeto, quando da análise de requisitos, os stakeholders são considerados como a principal fonte destes requisitos para o desenvolvimento do projeto. Por esse motivo, os stakeholders devem participar do projeto para fornecer suas necessidades e permitir a definição e validação de especificações de requisitos. 
Para Karlsen (2010) os stakeholders possuem um papel muito importante no desenvolvimento do projeto e uma de suas responsabilidades é fornecer recursos organizacionais e direções quando necessário. Suas efetivas participações tendem a antecipar possíveis problemas e minimizar seus efeitos.

Segundo McGee e Prusak (1994), a identificação de necessidades e requisitos de informação é a primeira tarefa do processo de gestão da informação (Figura 16).

Figura 16 - Tarefas do processo de gestão da informação

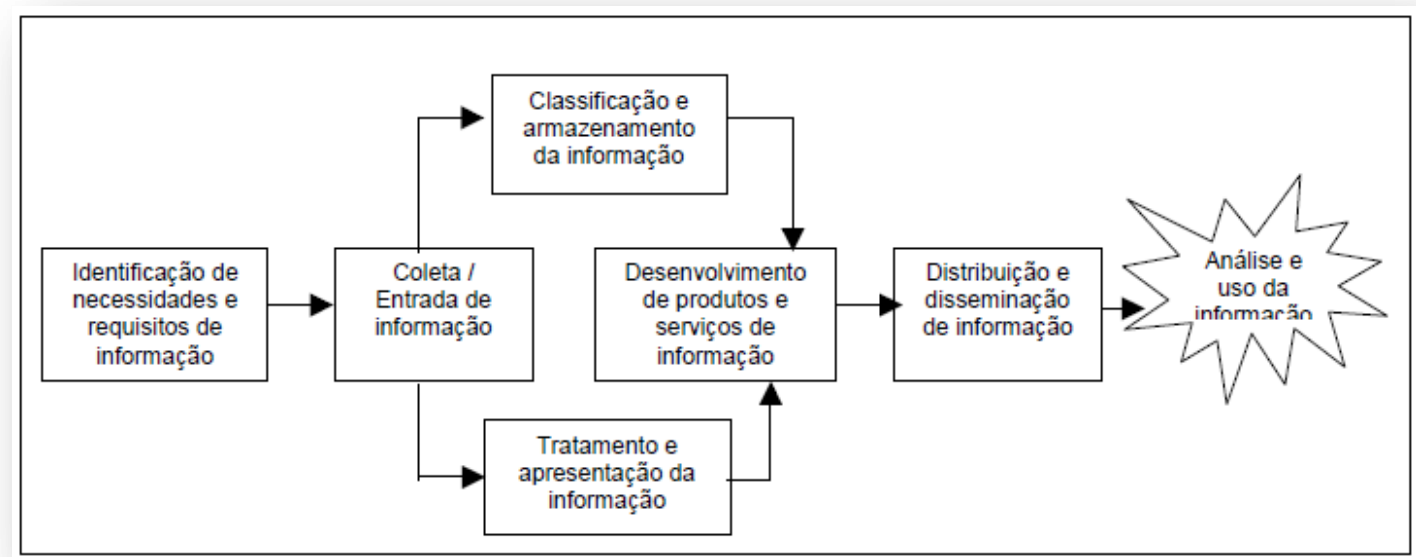

Fonte: McGee e Prusak (1994)

O processo de gestão da informação é um conjunto estruturado de atividades que inclui o modo como as empresas obtêm, distribuem e usam a informação e o conhecimento (DAVENPORT, 1998).

A gestão da informação em projetos tem como função a prospecção, seleção, tratamento, disponibilização, circulação e armazenamento das informações necessárias a elaboração e desenvolvimento do projeto. O foco principal da prospecção de informações está no ambiente externo e interno de modo a prover aos projetistas informações de qualidade para que estes possam elaborar o projeto com o menor grau de incerteza possível (FALSARELLA; MONTEIRO, 2007). 
De acordo com Ohnuma (2003) a informação serve como meio de comunicação e controle das atividades, e suporta a programação, o controle e a tomada de decisões em uma organização. Portanto, é necessário gerenciar as informações de forma a integrar as atividades e assim ser possível orientar e acompanhar todos os processos de gestão da informação.

Apesar do avanço tecnológico dos meios de comunicação, pode-se observar uma dificuldade pronunciada de comunicação entre as organizações ou dentro de uma mesma organização (GRILO, 2002). Considerando a grande quantidade de informações distribuídas entre os agentes envolvidos no processo de projeto, segundo Oliveira (2005), é necessária a eficaz coordenação dessas informações trocadas entre empreendedores, projetistas e construtores para que esse processo transcorra de maneira mais integrada.

A eficácia da comunicação da equipe de projeto parece ser altamente dependente de dois fatores inter-relacionados. Primeiro, os atos de comunicação dos membros da equipe, suas preferências para uso de meios específicos de comunicação e facilidade de acesso ao uso de ferramentas. Segundo, as competências dos chefes de equipes para facilitar, estimular e motivar seus subordinados a se comunicar eficazmente como um time (OTTER; EMMITT, 2007).

De acordo com Souza (2001), há duas regras básicas para um bom funcionamento de uma troca de informações. De início, é necessário que os agentes estabeleçam os meios de comunicação e seu modo de funcionamento; em seguida, que os papéis dos agentes sejam claramente definidos e que cada um aceite o papel que lhe foi destinado. Otter e Emmitt (2007) afirmam que o tempo para a elaboração do projeto é muitas vezes limitado e os membros da equipe podem executar vários projetos em diferentes estágios de desenvolvimento. Devido ao uso de diversas ferramentas de comunicação, a comunicação da equipe pode se tornar ineficaz sem uma orientação clara da gestão e envolvimento e compromisso de todos os membros da equipe.

Fazer a gestão da comunicação em projetos significa incluir os processos necessários para garantir no tempo, e de forma adequada, a geração, coleta, distribuição, armazenamento e a finalização do projeto (COELHO, 2006). 
De acordo com o PMBoK (2008), os gerentes de projetos gastam a maior parte do seu tempo comunicando-se com os membros da equipe e de outros agentes do projeto, que sejam internas (em todos os níveis da organização) ou externas à organização. Conduzir e estimular a efetiva comunicação entre os agentes envolvidos no projeto têm se tornado tarefas difíceis. Oliveira (2005) afirma que a troca constante de fornecedores, as relações dinâmicas entre os agentes e seus diferentes interesses (função de visões particulares e suas necessidades diferenciadas) são fatores que tornam difícil a flexibilização do processo e tendem a incrementar também a dificuldade na troca de informações. Para Ramsing (2009), investir em uma boa relação externa com clientes é benéfico, mas se as relações internas da organização são críticas e não funcionais, elas podem ter um grave efeito negativo nas relações externas a longo prazo e do mesmo modo resultados negativos a longo prazo para a organização. Quando as relações entre gerentes de projeto, gerentes funcionais (caso existam na organização) e membros da equipe são problemáticas e fora de equilíbrio, as probabilidades de conflito são elevadas. Os benefícios de alinhar a comunicação do projeto com a comunicação corporativa interna afetará não apenas mudanças que os gestores de projeto poderão concretizar nas equipes que eles coordenam e conduzem, promoverão uma mudança na forma de pensar da organização, na forma de planejar e executar seus projetos.

Os líderes de uma organização possuem uma importante missão de deixar claras a visão e metas da empresa, porém é de responsabilidade dos gestores de projetos liderar suas equipes, conduzindo-as a esses objetivos. A experiência em projetos industriais mostra que muitas vezes a equipe de projeto se preocupa apenas em realizar e cumprir suas atividades de uma forma isolada, sem ter à frente a visão do projeto como um todo e mais à frente ainda, os objetivos da organização. Conflitos internos de comunicação podem ser considerados um dos motivos que levam a equipe de projeto a esse tipo de atitude e esses conflitos devem ser identificados e solucionados pelo gestor do projeto.

De forma a diminuir as dificuldades na gestão da informação, como por exemplo: falta de organização das informações trocadas entre a equipe de projeto, perda de dados, deficiências de rastreabilidade e retrabalhos, faz-se necessária a competência de gestão da informação ao coordenador de projetos. Segundo Birnberg (1998), a principal função do coordenador consiste em comunicar, tendo em vista o papel de ligação entre os membros da equipe. Desta forma, os coordenadores devem dominar noções elementares de oratória, negociação e linguagem técnica, recebendo treinamento por parte da empresa. 
O guia PMBoK (2008) fornece uma visão geral dos processos de gestão das comunicações do projeto, que inclui os seguintes itens:

- Identificar as agentes envolvidos (ou stakeholders): o processo de identificação de todas as pessoas ou organizações que podem ser afetadas pelo projeto e de documentação das informações relevantes relacionadas aos seus interesses, envolvimento e impacto no sucesso do projeto.

- Planejar as comunicações: o processo de determinação das necessidades de informação de todos os agentes do projeto e definição de uma abordagem de comunicação.

- Distribuir as informações: o processo de colocar as informações necessárias à disposição doa agentes do projeto, conforme planejado.

- Gerenciar as expectativas dos agentes: o processo de comunicação e interação com os agentes envolvidos no projeto, para atender às suas necessidades e solucionar as questões à medida que ocorrem.

- Reportar o desempenho: o processo de coleta e distribuição de informações sobre o desempenho, incluindo relatórios de andamento, medições do progresso e previsões.

\subsection{GESTÃO DA QUALIDADE}

De acordo com a NBR ISO 9001:2008, o sistema de gestão da qualidade representa a parte do sistema de gestão da organização cujo enfoque é alcançar resultados com relação aos objetivos da qualidade, para satisfazer às necessidades, expectativas e requisitos dos agentes, conforme apropriado.

Projetar com qualidade é, com base nas necessidades e informações do cliente, gerar alternativas (soluções) que realmente resolvam o problema proposto, que sejam exequíveis e economicamente viáveis e decidir de forma racional entre elas (OLIVEIRA; FABRÍCIO; MELHADO, 2004).

Dentro da busca da qualidade, envolvendo mudanças nas relações entre os seus diversos agentes, percebe-se que o processo de projeto tem um grande destaque como elo fundamental 
da cadeia produtiva. $\mathrm{O}$ projeto, além de instrumento de decisão sobre as características do produto, influi diretamente nos resultados econômicos dos empreendimentos e interfere na eficiência de seus processos (MELHADO et al., 2005).

De acordo com Grilo (2002), muitos projetistas acreditam que sistemas da qualidade implicam em rotinas de trabalho adicionais. Na verdade, são apenas mudanças básicas requeridas no projeto, como maior número de controles em diferentes fases; maior número de pontos de verificação, com o intuito de demonstrar continuamente a conformidade com os requisitos; aceitação de alterações inevitáveis como ações positivas para o atendimento dos requisitos do cliente; e controle sistemático das alterações.

Em adição a isso, considerando-se a multidisciplinaridade dos projetos, Melhado et al. (2005) afirmam que o aumento do volume de produtos gerados (disciplinas de projeto), a elevação do fluxo de informações e a necessidade de maior integração e compatibilização entre os intervenientes, em prazos de desenvolvimento global cada vez mais reduzidos, implicaram uma maior demanda e uma maior complexidade na gestão do processo de projeto.

Com o aumento dos agentes envolvidos e maior complexidade de gestão, faz-se necessária a criação de mecanismos de avaliação, verificação e controle em cada etapa do projeto (Figura 17). Esta prática deve ser aplicada ao projeto como um todo, mesmo que parte dele seja elaborada por terceiros. 
Figura 17 - Avaliação, verificação e controle do processo de projeto

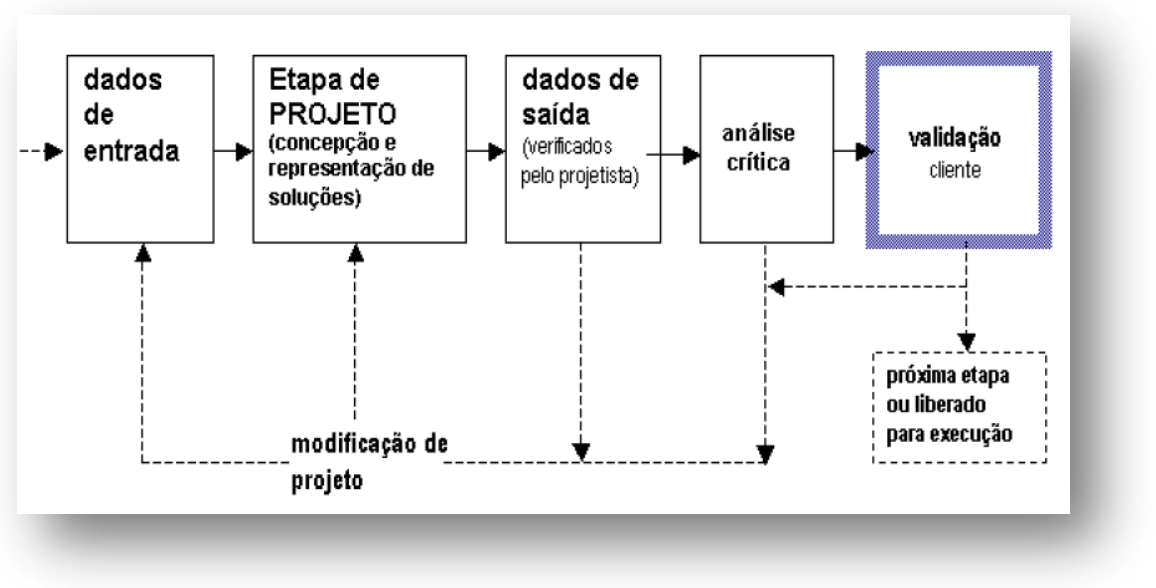

Fonte: Melhado et al. (2005)

Analisando-se a Figura 17, e considerando o controle da qualidade nas etapas do projeto, as necessidades dos clientes e seus objetivos podem ser definidos como dados de entrada do processo de projeto. Durante a execução do projeto, profissionais atenderão a esses requisitos considerando as melhores soluções técnicas e econômicas. A análise crítica é uma etapa fundamental do processo, pois é possível identificar e minimizar os desvios do projeto em relação aos requisitos inicialmente definidos. Como dados de saída do processo, por fim, é entregue o projeto de acordo com as informações de entrada.

Vale a pena ressaltar que, na etapa de verificação, possíveis erros de projeto são identificados e corrigidos. Segundo Han et al. (2013), quando um erro é identificado, muitas vezes é exigido um retrabalho a realizar, o qual envolve mais tempo e recursos a serem gastos.

Esses erros que geram modificações de projeto podem ser procedentes de falhas humanas, ou, o que se tem observado muito, mudanças em premissas e informações de referência oriundas de um ou mais stakeholders. Han et al. (2013) afirmam que, em geral, as empresas de projeto não medem o número de erros que elas produzem e, em particular, elas geralmente falham ao proceder adequadas verificações, análises e modificações de projeto. Além disso, os erros não são identificados imediatamente e o grau de retrabalho exigido cresce quando os erros permanecem sem serem detectados por longos períodos de tempo. 
Portanto, as atividades de avaliação e verificação possuem um papel muito importante no processo de projeto e, por meio delas, é possível realizar o controle da qualidade dos projetos. De acordo com PMBoK (2008), realizar o controle da qualidade é o processo de monitoramento e registro dos resultados da execução das atividades de gestão da qualidade para avaliar o desempenho e recomendar as mudanças necessárias, sendo realizado durante todo o projeto.

Oliveira (2005) afirma que, de uma forma geral, pode-se considerar que a qualidade do projeto depende da qualidade das etapas intermediárias de sua execução: qualidade do programa (atendimento as necessidades do cliente, equacionamentos financeiro-econômico e comercial), qualidade das soluções de projeto (atendimento às exigências de desempenho da edificação, sustentabilidade e construtibilidade), qualidade da apresentação do projeto (clareza, detalhamento, informações completas e facilidade de consulta), qualidade dos serviços associados ao projeto (cumprimento de prazos e custos, compatibilização entre disciplinas de projeto, acompanhamento do projeto durante a obra e assistência técnica) e também da qualidade de sua utilização durante a fase de execução da obra.

Pelo exposto, pode-se afirmar que as organizações possuem dificuldades em garantir a qualidade de seus projetos. Isto se deve, dentre outros fatores, às falhas da coordenação de projetos, carência de recursos físicos e humanos, resistência dos profissionais e estrutura organizacional ineficiente das empresas.

De acordo com Melhado (1994), as ações de organização e gestão são primordiais, em que se incluem:

- adotar métodos gerenciais mais participativos e descentralizados;

- implementar a garantia da qualidade por todos e não apenas por meio de um departamento ou grupo responsável pela qualidade;

- valorizar a capacidade criativa e de autocontrole dos profissionais;

- treinar uma postura proativa frente aos clientes internos e externos. 
De acordo com o PMBoK (2010), a gestão da qualidade do projeto inclui os processos e as atividades da organização executora que determinam as políticas de qualidade, os objetivos e as responsabilidades, de modo que o projeto satisfaça às necessidades para as quais foi empreendido. Os processos de gestão da qualidade sugeridos pelo PMBoK (2010) são:

- Planejar a qualidade: identificar os requisitos e/ou padrões de qualidade do projeto e do produto, bem como documentar de que modo o projeto demonstrará a conformidade.

- Realizar a garantia da qualidade: o processo de auditoria dos requisitos de qualidade e dos resultados das medições do controle de qualidade para garantir que sejam usados os padrões de qualidade e as definições operacionais apropriadas.

- Realizar o controle da qualidade: o processo de monitoramento e registro dos resultados da execução das atividades de qualidade para avaliar o desempenho e recomendar a mudanças necessárias.

Estes processos possuem o objetivo de implementar o sistema de gestão da qualidade por meio de políticas e procedimentos de atividades de melhoria contínua realizadas durante todo o projeto.

\subsection{GESTÃO DO CONHECIMENTO}

O reflexo de uma estrutura organizacional aderente às estratégias da organização é sua comunicação. Nas empresas inovadoras, a comunicação não é transmitida de cima para baixo seguindo um só caminho e, normalmente, é compartilhada por um número significativo de interessados de forma a atenderem seus requisitos. Há pelo menos três variáveis a serem consideradas na gestão da inovação: informação, tempo e pessoas. As empresas que melhor gerenciam a inovação são aquelas que disponibilizam a informação certa para a pessoa certa na hora certa. Esta capacidade só é conseguida por meio de um processo de gestão do sistema de comunicação que, no seu estágio de maior abrangência, constitui-se no que é hoje chamado de gestão do conhecimento (RABECHINI JÚNIOR; CARVALHO; LAURINDO, 2002).

A gestão do conhecimento sempre existiu, na troca de experiência entre trabalhadores, na passagem de conhecimento do artesão para o aprendiz, mas o conceito começou a ser difundido no meio empresarial a partir dos anos 90. Com a base da economia industrial 
passou da utilização de recursos naturais para recursos intelectuais, os executivos foram impulsionados a examinar como o conhecimento fundamentava seus negócios e como este conhecimento poderia ser utilizado como fonte de vantagem competitiva (MEDEIROS, 2012).

Segundo Santiago Júnior (2004), muitas vezes, a maior parte dos conhecimentos que uma organização necessita para se manter competitiva ela já possui; no entanto, esses conhecimentos estão, por vários motivos, inacessíveis. A criação de um ambiente propício para identificar, criar e disseminar o conhecimento agrega valor aos processos e a coloca a organização no rumo de atingir suas metas.

De acordo com Terra (2005), são vários os aspectos relacionados à gestão do conhecimento: papel da alta administração, cultura e estrutura organizacionais, práticas de gestão de recursos humanos, impacto dos sistemas de informação e mensuração de resultados, alianças estratégicas etc. Esta abordagem reflete a compreensão de que a gestão do conhecimento implica, necessariamente, a coordenação sistêmica de esforços em vários planos: organizacional e individual; estratégico e operacional; formais e informais.

Há vários tipos de ferramentas e tecnologias que podem ser utilizadas para desenvolver a gestão do conhecimento, porém é importante que todas as informações relevantes para a gestão de projetos estejam organizadas antes de serem introduzidas na gestão do conhecimento. Podemos chamar essas informações de banco de dados de projetos, o qual pode ser criado a partir de dados como pontos fortes, fracos e desvios encontrados no processo de projeto, da visão e avaliação do cliente, de indicadores utilizados no projeto, dentre outros. De acordo com Quintão (2003) a gestão do conhecimento tem como princípio básico a multiplicação dos conhecimentos existentes na organização para melhorar o desempenho das pessoas e, consequentemente, da organização.

As ferramentas da tecnologia da informação oferecem apoio a pelo menos uma das atividades de geração, codificação ou transferência de conhecimento. Essas ferramentas podem ser softwares específicos com fóruns ou bancos de dados que podem ser destinados ao armazenamento, disseminação ou descobrimento do conhecimento (QUINTÃO, 2003). 
Santiago Júnior (2004) afirma que o grande desafio é desenvolver uma metodologia que torne possível a reutilização do conhecimento existente na organização, bem como o uso de meios para captação de novos conhecimentos. Pesquisas realizadas por consultorias especializadas, em grandes corporações, levantaram que iniciativas voltadas para gestão do conhecimento podem trazer grandes benefícios para:

- Tomada de Decisão;

- Gestão dos Clientes;

- Respostas às Demandas de Mercado;

- Desenvolvimento de Habilidades dos Profissionais;

- Produtividade;

- Lucratividade;

- Compartilhamento das Melhores Práticas;

- Redução de Custos.

\subsection{CONSIDERAÇÕES FINAIS DA REVISÃO BIBLIOGRÁFICA}

O estudo da literatura permite identificar pontos importantes e conceitos que serão utilizados quando da análise dos estudos de caso.

Considerando a gestão de projetos, é de extrema relevância definir e identificar:

- os papéis e responsabilidades dos agentes envolvidos, e sua coerência em termos de estruturas organizacionais e modalidades de contratação adotadas;

- o bom entendimento do escopo e das informações iniciais (dados de entrada), que permita que o projeto apresente soluções técnicas mais adequadas e mais precisas; 
- os riscos associados ao projeto, suas probabilidades de ocorrência, prováveis impactos e possíveis soluções para evitá-los ou, caso contrário, para mitigá-los;

- as formas de gestão da informação necessárias, com qualidade e nível de detalhe pertinentes, em todas as etapas de cada um dos processos, para que seja possível gerar resultados com qualidade e que atendam aos requisitos do cliente;

- a adequada tecnologia de representação ou de modelagem das informações do projeto, coerente com as necessidades do cliente e com os objetivos do projeto, bem como associada às reais competências e experiência de projetos anteriores na mesma plataforma, necessárias para formação da equipe multidisciplinar e sua gestão.

A coordenação de projetos, por seu papel na integração e orientação da equipe multidisciplinar, tem como responsabilidade, exercer liderança, motivar os envolvidos, distribuir tarefas e disciplinar a comunicação dentro da equipe e com os demais agentes do projeto.

A realização de práticas de avaliação, verificação e controle em cada etapa do projeto de forma a garantir a qualidade dos serviços executados e a decisão entre alternativas para a solução de problemas técnicos faz da coordenação uma área complexa, na qual o coordenador necessita de habilidades para que seu trabalho se torne eficaz. Essas práticas podem ser fundamentais para se evitarem retrabalhos, aumento de custos e possíveis atrasos na entrega do projeto. Particularmente, com o envolvimento de terceiros (subcontratados), a atenção à sua qualificação e supervisão, além de um efetivo controle sobre os elementos de projeto produzidos, podem ser fatores fundamentais para o sucesso ou fracasso do projeto.

Durante a execução do projeto, é imprescindível que a coordenação mantenha a organização das informações e, com o apoio da gestão de projetos, sejam elaboradas rotinas de controle de indicadores, análise dos dados de avaliação do cliente, reuniões de análise crítica com a equipe estabelecendo pontos fortes, fracos e desvios do projeto. Essas informações formarão um banco de dados do projeto e após o seu encerramento, com a utilização dos conceitos da gestão do conhecimento, esses dados poderão gerar uma vantagem competitiva, agregando valor à organização e a seus projetos. 


\section{ESTUDOS DE CASO}

\subsection{CARACTERIZAÇÃO DAS EMPRESAS}

\subsubsection{Empresa A}

A projetista é uma empresa brasileira de projetos, gerenciamento, engenharia e fornecimento de pacotes EPC/EPCM fundada em 1987. Possui matriz na cidade de São Paulo e filiais em: Vitória (ES), Belo Horizonte (MG), Salvador (BA), São Luís (MA), Belém (PA) e Neuquén, na Argentina. Além destas unidades, conta ainda com grupos-tarefa alocados no Brasil e no exterior.

Com cerca de 2.300 profissionais (onde $83 \%$ atuam na área técnica e 17\% na administrativa), a projetista possui diversos clientes de diferentes segmentos como Mineração, Metalurgia, Siderurgia, Fertilizantes, Óleo e Gás, Petroquímica, Infraestrutura, Energia, Projetos Portuários, Gerenciamento de Implantação e Construções.

A empresa realiza serviços de:

- consultoria e estudos (estudos de mercado / viabilidade técnico-econômica, impactos ambientais, HAZOP, análise de riscos de projetos);

- engenharia de projeto conceitual, básico e detalhado (possui corpo técnico das disciplinas de Processos Químicos, Processos Mínero Metalúrgicos, Sistemas de Utilidades, Tubulações, Sistemas de Combate a Incêndio, Mecânica, Sistemas de Ventilação e Ar Condicionado, Eletricidade, Instrumentação, Controle e Automação, Arquitetura, Estruturas Metálicas, Estruturas de Concreto e Fundações, Infraestrutura Civil, Geologia e Geotecnia);

- Suprimentos (compras de equipamentos e materiais, diligenciamento de fabricação, inspeção de fabricação, coordenação e logística de transporte, gestão de materiais (controle de almoxarifado);

- Comissionamento /Assistência à Partida e Pré-Operação;

- Gerenciamento de Implantação e Construções. 
A gestão de projetos na Empresa A está vinculada ao corpo gerencial da empresa formado pelos coordenadores de projeto e departamento de planejamento. Tanto os coordenadores quanto os planejadores respondem diretamente a cada uma das quatro diretorias dos segmentos industriais e gerenciamento (Figura 18).

Os segmentos industriais de atuação da projetista são: Mineração, Siderurgia e Logística; Óleo e Gás, Química e Petroquímica; Infraestrutura e Energia; além de Gerenciamento de Implantação e Construções. Na Figura 18 é apresentado o organograma da empresa.

Figura 18 - Organograma da Empresa

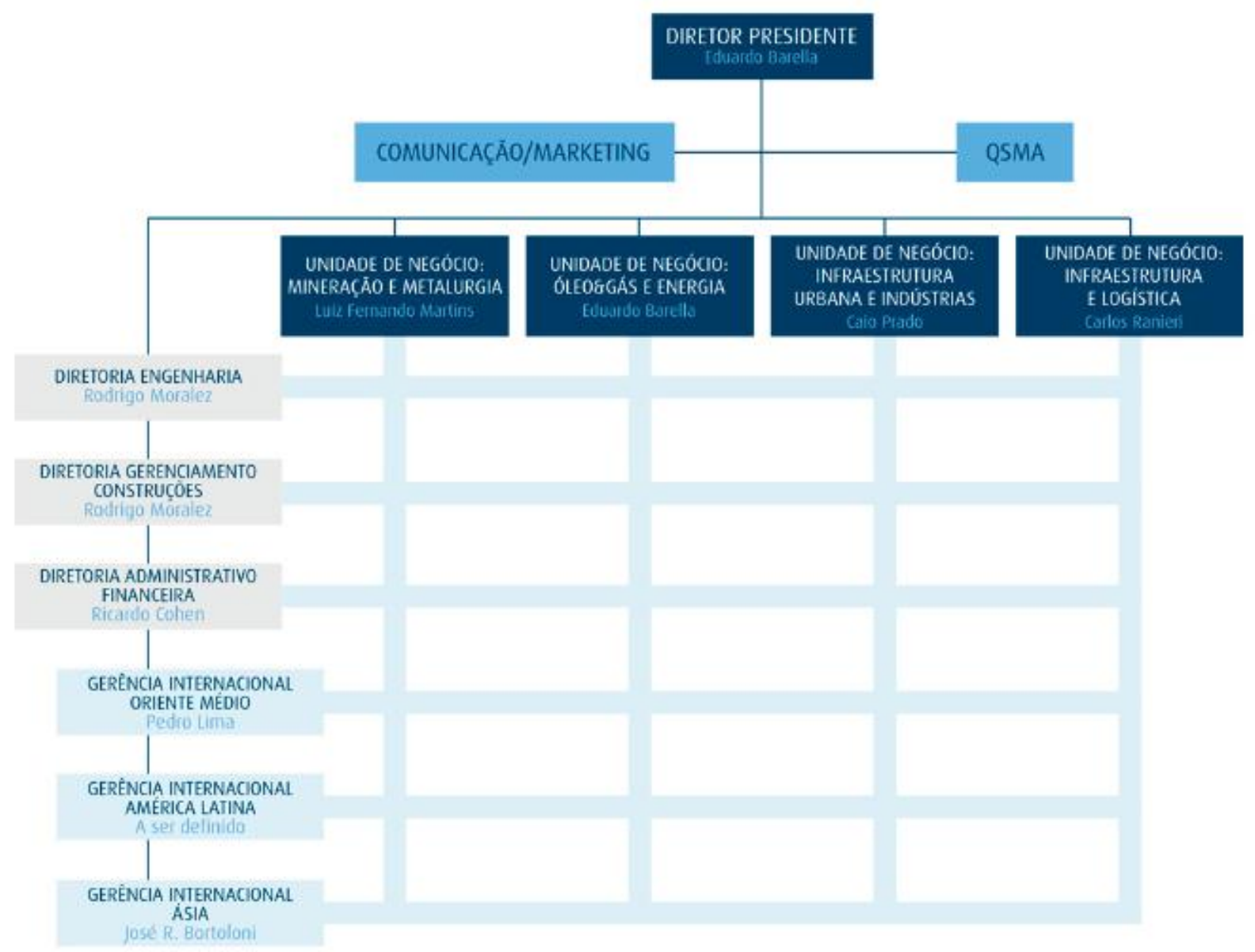

Fonte: Site da empresa 


\subsubsection{Empresa B}

A empresa de Engenharia Consultiva foi fundada em 1990. Possui matriz em São Paulo e filiais no Rio de Janeiro/RJ e Esteio/RS, oferecendo serviços de desenvolvimento de Projetos Básicos e Detalhados, Engenharia de Suprimentos, Gerenciamento de Empreendimentos, Serviços em EPC’M, Estudos Ambientais, Avaliações e Diagnósticos.

Com cerca de 800 colaboradores, a empresa atua nos segmentos industriais de Óleo, Gás e Petroquímica (Refinarias, Plantas Petroquímicas, Dutos e Terminais), incluindo Meio Ambiente e Recursos Hídricos (Saneamento de Água e Esgoto, Estudos Ambientais e Recursos Hídricos) e Infraestrutura (Transportes Multimodais, Infraestrutura Urbana e Energia).

A empresa possui uma ampla gama de disciplinas desenvolvidas por profissionais qualificados: analistas de sistemas, coordenadores, gerentes, engenheiros civis, engenheiros eletricistas, especialistas em equipamentos, instrumentação, tubulação, processos químicos, materiais, planejamento, qualidade e HSE, entre outros. O organograma é apresentado na Figura 19.

Figura 19 - Organograma da Empresa B

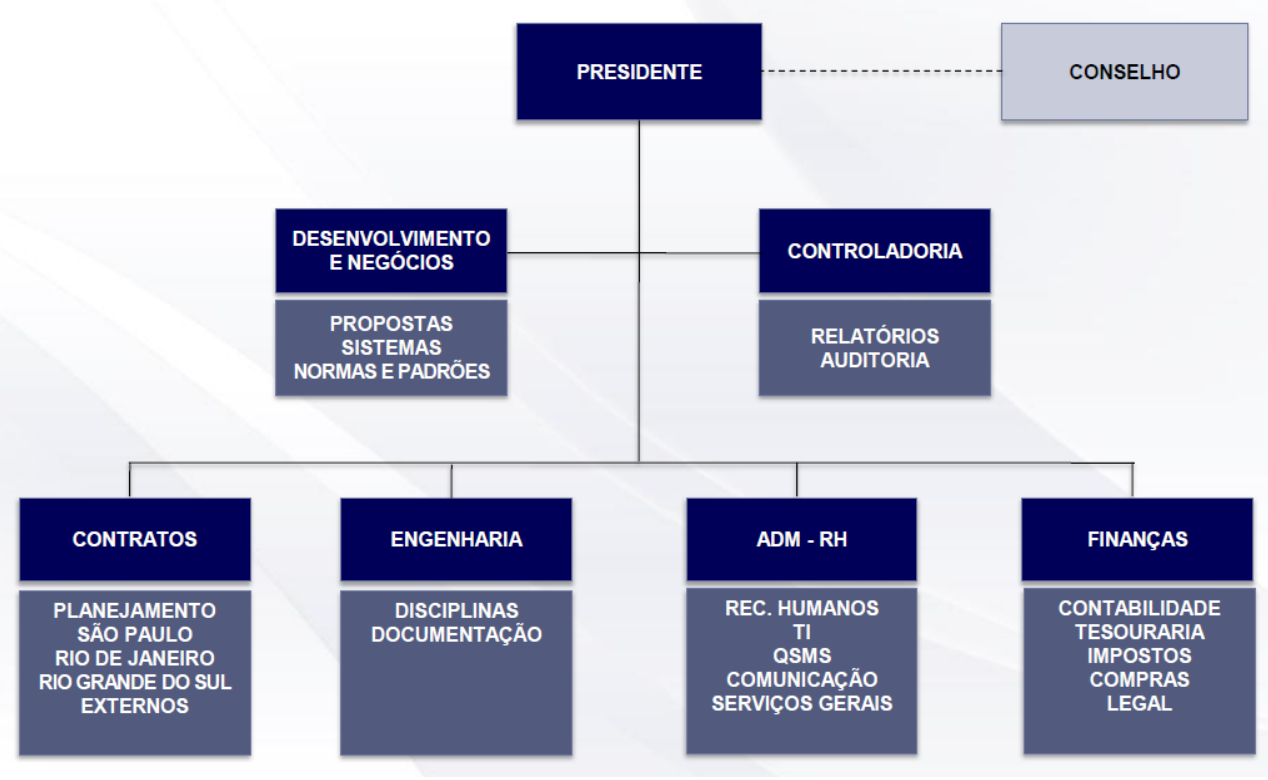

Fonte: Site da empresa 
Os sistemas e recursos utilizados pela Empresa B são apresentados na Figura 20.

Figura 20 - Sistemas e Recursos utilizados pela Empresa B

\begin{tabular}{|c|c|c|c|c|}
\hline INICIO DO PRONETO & PLANEJAMENTO & EQUIPE DE PRONETO & $\begin{array}{l}\text { ANALISE DE CONSISTÉNCLA } \\
\text { (Documentacilo do cliento) }\end{array}$ & $\begin{array}{l}\text { CONTROLE DE DOCUMENTOS } \\
\text { (DMS } \rightarrow \text { GED) }\end{array}$ \\
\hline $\begin{array}{l}\text { - Orçamento } \\
\text { - Padröes do Cliente } \\
\text { - Lista de Documentos } \\
\text { - Software CAD/CAE } \\
\text { - Equipe de Projetos } \\
\text { - Gerente de Projeto } \\
\text { - Coordenador de Projeto } \\
\text { - Job Lideres }\end{array}$ & $\begin{array}{l}\text { - PRIMAVERA } \\
\text { - Definiça das atividades } \\
\text { principais } \\
\text { - Cronograma de controle } \\
\text { desenhos de fornecedores } \\
\text { - Lista Final de Documentos } \\
\text { - Histograma } \\
\text { - Controle de horas } \\
\text { - Centrolee Relatórios }\end{array}$ & $\begin{array}{l}\text { - Apresentaça dos } \\
\text { projetos } \\
\text { - Definiçáo de Metas } \\
\text { - Treinamentos } \\
\text { - Pontos Criticos } \\
\text { - Lista de Documentos } \\
\text { - Antecessor } \\
\text { - Doc, de referéncia }\end{array}$ & $\begin{array}{l}\text {-PFDs } \times \text { Data Sheet } \\
\text { - PFDs } \times \text { P\&IDs } \\
\text { - P\&IDs } \times \text { Indice de Linha } \\
\text { - P\&IDs } \times \text { Padróes Projeto } \\
\text { - P\&ID } \times \text { Plano de Plot } \\
\text { - P\&IDs } \times \text { Diagrama Eletrico } \\
\text { - P\&IDs } \times \text { Diretriz de } \\
\text { Controle }\end{array}$ & $\begin{array}{l}\text { - Doc. Cliente } \rightarrow \text { GED-REF } \\
\text { - Doc. Projeto } \rightarrow \text { GED PROJ } \\
\text { - Doc. Fornecedor } \rightarrow \text { GED-SUP } \\
\text { - Procedimento } \rightarrow \text { GED-QUALL } \\
\text { - Transmissóes } \\
\text { - Status de Doc. Historico } \\
\text { Reporte } \\
\text { Follow-Up (interno e externo) }\end{array}$ \\
\hline & & & & $\begin{array}{l}\text { MATERIANS } \\
\text { GERENCLAMENTO E CONTROLE }\end{array}$ \\
\hline $\begin{array}{l}\text { - Monitoramento de budget } \rightarrow \\
\text { IFS } \\
\text { - Analise de tendencias } \\
\text { (escopo, custo) } \\
\text { - Comprometimento } \\
\text { - Ordem de mudança } \\
\text { - Receitas \& Pagamentos } \\
\text { - Subcontratados. }\end{array}$ & & $\begin{array}{l}\text { Sistema } \\
\text { Recurso }\end{array}$ & 2 & $\begin{array}{l}\text { - Dutos } \rightarrow \text { SIGMA-TUB } \\
\text { - Eletrica } \rightarrow \text { SIGMA ELINS } \\
\text { - Instrumentaço } \rightarrow \text { SIGMA } \\
\text { ELINS }\end{array}$ \\
\hline $\begin{array}{l}\text { ASSESSORIA DE } \\
\text { CONSTRUCGAO }\end{array}$ & ENGENHARIA & $\begin{array}{l}\text { SOFTWARE DE } \\
\text { ENGENHARIA }\end{array}$ & MODELOS 30 & SOFTWARES INTEUGENTES \\
\hline $\begin{array}{l}\text { - Estudos de campo } \\
\text { - Soluça de questóes de } \\
\text { projeto } \\
\text { - Controle de qualidade da } \\
\text { construçäo } \\
\text { - Comissionamento } \\
\text { (definiça e rastreamento) } \\
\text { - Tie-Ins de monitoramento } \\
\text { - As Built }\end{array}$ & $\begin{array}{l}\text { - Calculos - } \\
\text { especificaçoes } \\
\text { - Definiçaso: Equipamento, } \\
\text { Materiais, Instrumentos } \\
\text { - Requisiçáo de Material } \\
\text { - Analises de propostas } \\
\text { tenicas } \\
\text { - Interface com as } \\
\text { ferramentas de } \\
\text { Engenharia }\end{array}$ & $\begin{array}{l}\text { - Pro ll Invensys } \\
\text { - CAESAR / TRIFLEX } \\
\text { - PV Elite (Intergraph) } \\
\text { - PTW-Analise de } \\
\text { Sistemas Eletricos } \\
\text { - CONcrete DESign } 3 \\
\text { - TEKLA } \\
\text { - STRAT - Metalica Civill }\end{array}$ & $\begin{array}{l}\text { - PDMS / POS / SMART PLAN } \\
\text { - Comunicaçäo com SIGMA } \\
\text { - Tubulaça, estrutura. } \\
\text { eletrica, instrumentaça. } \\
\text { concreto. } \\
\text { - Suporte de tubulaçào } \\
\text { - FStatus } \rightarrow \text { 3D Lberaçaso de } \\
\text { Projeto interdisciplinar } \\
\text { - SPOOLER / SPOLGEN }\end{array}$ & $\begin{array}{l}\text { - SISGRAPH Software } \\
\text { SMART PSID, Eletrica. } \\
\text { Instrumentaçäo } \\
\text { - INNOTEC - SIEMENS Software } \\
\text { COMOS PSID, Eletrica, } \\
\text { Instrumentaça, Sistema } \\
\text { Operacional. } \\
\text { - Interface com ferramentas de } \\
\text { engenharia. }\end{array}$ \\
\hline
\end{tabular}

Fonte: Site da empresa

Na Tabela 1 são apresentadas as principais características das empresas estudadas, como a especialidade, o ano de fundação da empresa, a quantidade de funcionários e áreas de atuação.

Tabela 1 - Caracterização das empresas estudadas

\begin{tabular}{|c|c|c|c|c|}
\hline \multicolumn{5}{|c|}{ Caracterização das Empresas Estudadas } \\
\hline Empresa & Especialidade & Ano (Fundação) & $\begin{array}{c}\text { № de } \\
\text { Funcionários }\end{array}$ & Áreas de Atuação \\
\hline A & $\begin{array}{c}\text { Engenharia de Projeto Conceitual, } \\
\text { Básico e Detalhado / Suprimentos/ } \\
\text { Gerenciamento / Consultoria e } \\
\text { Estudos / Pacotes EPC e EPCM }\end{array}$ & 1987 & 2.300 & $\begin{array}{c}\text { Mineração, Metalurgia, Siderurgia, Fertilizantes, Óleo e Gás, } \\
\text { Petroquímica, Infraestrutura, Energia, Projetos Portuários, } \\
\text { Gerenciamento de Implantação e Construções }\end{array}$ \\
\hline B & $\begin{array}{c}\text { Projetos Básicos / Projetos de } \\
\text { Detalhamento / Engenharia de } \\
\text { Suprimentos / Gerenciamento de } \\
\text { Empreendimentos / Serviços em } \\
\text { EPC'M / Estudos Ambientais }\end{array}$ & 1990 & 800 & $\begin{array}{c}\text { Terminais), Meio Ambiente e Recursos Hídricos (Saneamento de Água e } \\
\text { Esgoto, Estudos Ambientais e Recursos Hídricos) e Infraestrutura } \\
\text { (Transportes Multimodais, Infraestrutura Urbana e Energia). }\end{array}$ \\
\hline
\end{tabular}

Fonte: Dados de pesquisa 


\subsection{EMPRESA A - ESTUDO DE CASO 1}

\subsubsection{Caracterização do Empreendimento}

Trata-se do projeto de uma usina siderúrgica voltada à fabricação de laminados de aço, que terá capacidade anual de produção de 2,5 milhões de toneladas de placas.

O empreendimento tem investimento estimado em $\mathrm{R}$ \$,8 bilhões e terá geração de 16 mil empregos na fase de implantação. Além da usina para produzir placas e aços laminados, o empreendimento compreende a construção de um acesso ferroviário, para receber o minério de ferro, e a construção de um terminal fluvial no rio Tocantins, para receber o carvão mineral e fazer o escoamento da produção siderúrgica até o Terminal Portuário de Vila do Conde, em Barcarena (PA). Além de atender à produção da siderúrgica, a futura hidrovia deverá servir a outras atividades socioeconômicas da região.

\subsubsection{Etapas do Projeto}

O Projeto Conceitual de Infraestrutura foi realizado pela Empresa A. O prazo contratual para entrega do projeto era de 48 dias, porém foi constatado que ocorreu um atraso de pelo menos 15 dias na entrega do projeto. As justificativas para este atraso foram evidenciadas em relatórios emitidos pela projetista, a saber: envio por parte do cliente de informações inconsistentes ocasionando reestudo do projeto; atraso do cliente no retorno de respostas às solicitações de informações; equipe de infraestrutura Com dedicação compartilhada (havia recurso trabalhando em outro projeto em outros andares ou até mesmo viajando por conta de outros contratos) e dificuldade na comunicação.

O Projeto Básico de Infraestrutura também foi realizado pela Empresa A. O prazo contratual para elaboração foi inicialmente de 110 dias, porém foi realizado um aditivo de custo e prazo ao projeto, acrescentando 92 dias corridos ao prazo inicial. O aditivo foi justificado por trabalhos realizados em regime de horas extras (projeto básico de fundação), com vistas a compensar o atraso no recebimento das informações (planos de carga) por parte do cliente.

Após a conclusão e entrega do projeto básico, o cliente realizou um novo contrato para execução do projeto detalhado com a Empresa A, o qual será descrito mais adiante no texto desta Dissertação. 


\subsubsection{Escopo do Projeto}

Conforme descrito no contrato e propostas técnica e comercial, utilizando seu know-how técnico e gerencial, a projetista possuía a responsabilidade de elaborar os projetos descritos abaixo, a saber:

- Projeto detalhado de infraestrutura para todas as áreas da Usina;

- Projeto detalhado do sistema de drenagem pluvial provisória (etapa de obras) de todas as áreas da Usina;

- Projeto detalhado do aterro de inertes, aterros sanitário e industrial para atendimento da Usina, tanto na etapa de obras, quanto na etapa de operação da planta industrial;

- Projeto detalhado da Central de Materiais Descartáveis para atendimento da Usina, tanto na etapa de obras, quanto na etapa de operação da planta industrial.

Para elaboração dos projetos acima foram vendidas $5.000 \mathrm{Hh}$ (cinco mil horas técnicas) de engenharia e $1.000 \mathrm{Hh}$ (mil horas técnicas) de coordenação e planejamento, sendo o prazo contratual de cinco meses, pelo regime de contratação por preço global, no valor total de R\$ $754.594,86$ para execução dos serviços. Na Figura 21 é apresentada a planta geral do empreendimento. 
Figura 21 - Planta geral do projeto - Estudo de Caso 1

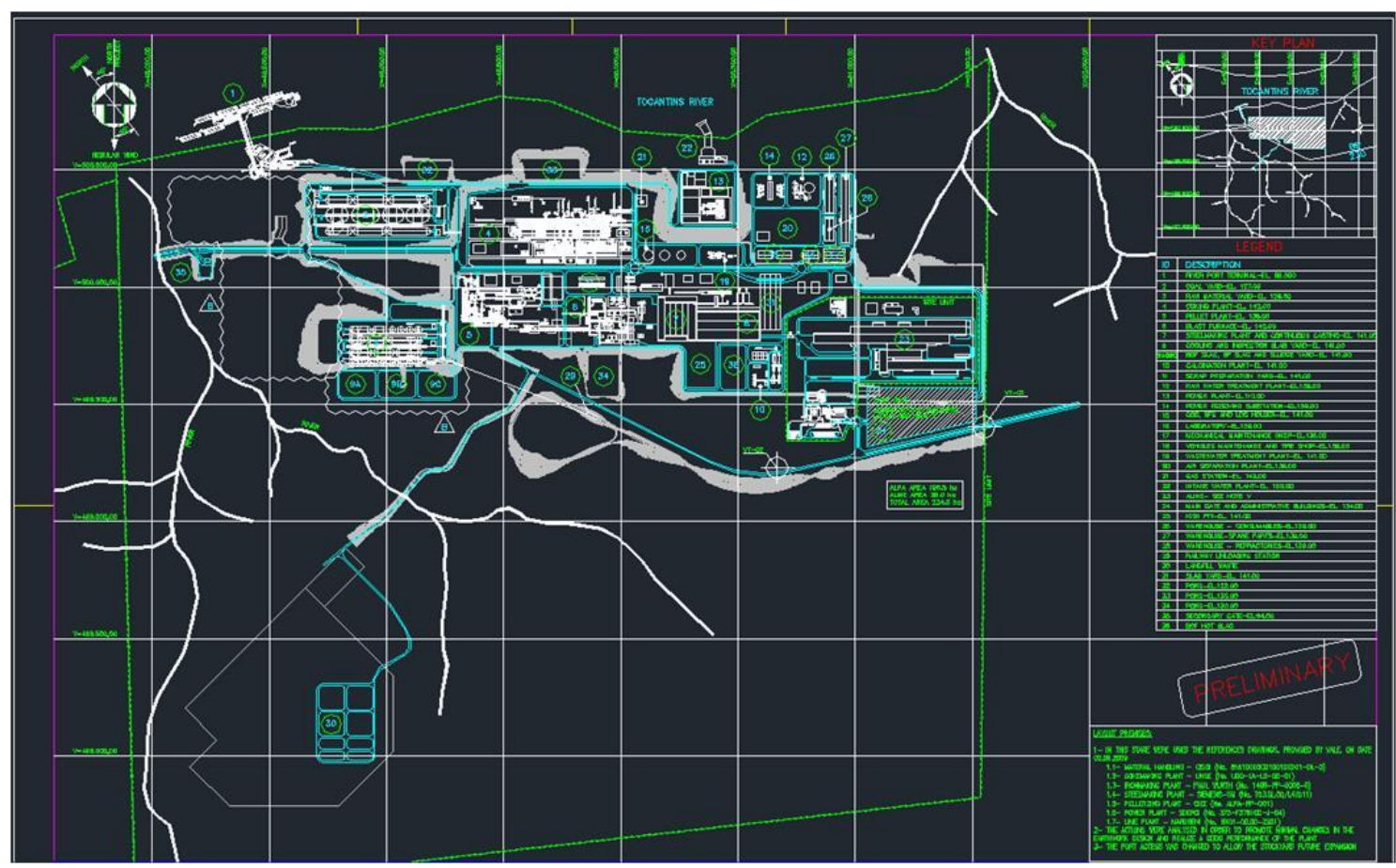

Fonte: Dados de pesquisa

\subsubsection{Agentes Envolvidos e Organograma do Empreendimento}

Foram identificados como principais agentes do empreendimento:

- Cliente: composto por um gerente de contrato, coordenador de projeto, técnico de planejamento, assistente de arquivo técnico e pequena equipe de engenharia para verificação e aprovação do projeto. O cliente participava das reuniões gerenciais e de reuniões técnicas de projeto de forma a acompanhar o desenvolvimento do projeto;

- Consultoria técnica externa: contratada pela projetista para elaboração de projetos de drenagem;

- Projetista: a estrutura organizacional apresenta uma conformação matricial na qual, de um lado, são identificadas as grandes áreas do projeto com os seus respectivos gerentes, responsáveis pela coordenação e gerenciamento das atividades de engenharia pertinentes a cada uma, e, de outro lado, as diversas especialidades responsáveis pelo desenvolvimento 
destas atividades. Os gerentes de área e os coordenadores das especialidades estão subordinados ao gerente do projeto.

Os profissionais de cada unidade do organograma eram mobilizados nas etapas apropriadas de acordo com as previsões do planejamento. A estrutura de subordinação ao gerente do projeto é apresentada na Figura 22.

Figura 22 - Organograma do Estudo de Caso 1 - Empresa A

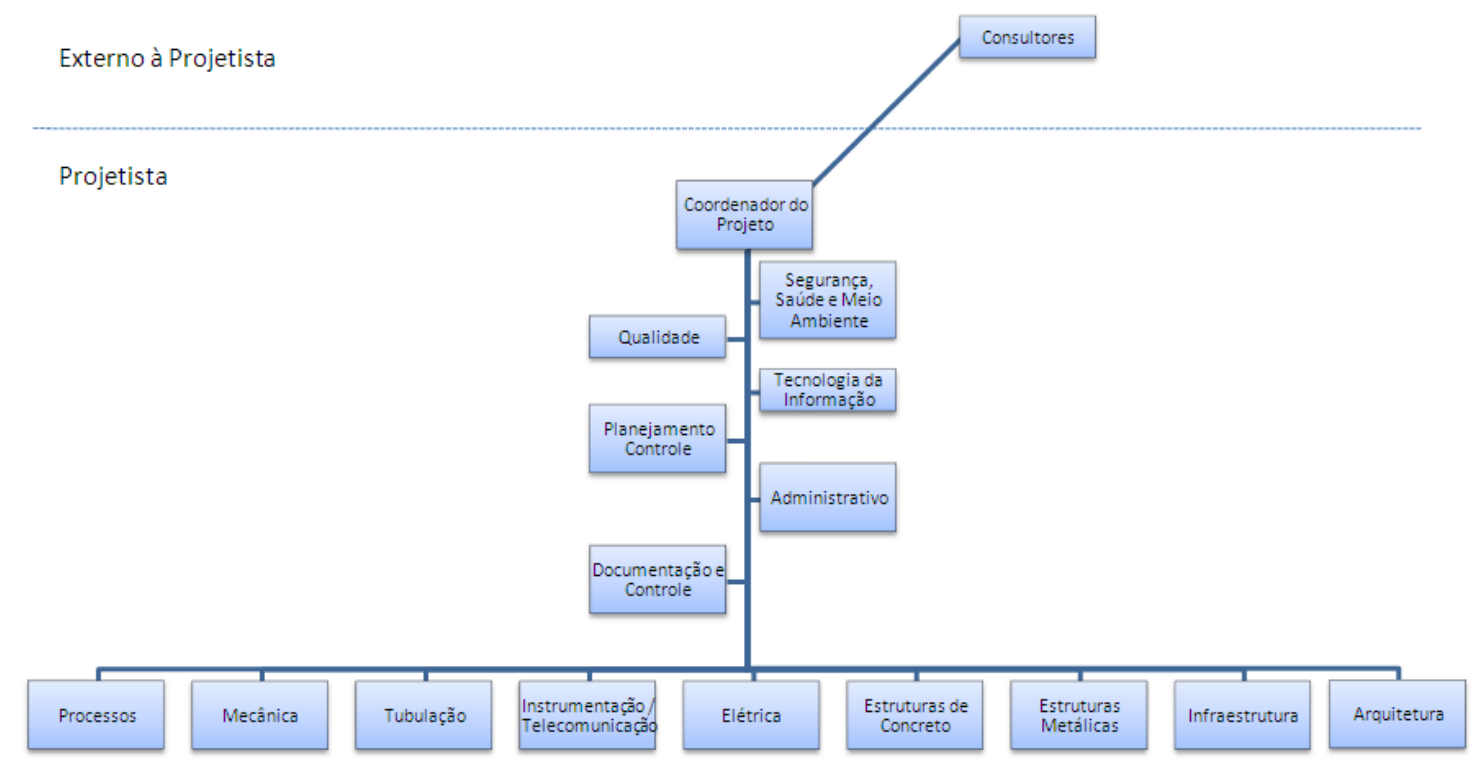

Fonte: Dados de pesquisa

\section{Grupo de Assessoria}

- Consultores

- Segurança, Saúde e Meio Ambiente

- Qualidade

- TI (Tecnologia da Informação)

\section{Grupo de Engenharia de Apoio}

- Mecânica 
- Processos

- Civil

- Elétrica

- Tubulação e Sistemas

- Telecomunicações

- Automação Industrial

Grupo de Engenharia Civil

- Estruturas de Concreto

- Estruturas Metálicas

- Arquitetura

- Infraestrutura

Grupo de Planejamento e Controle

- Planejamento

- Controle de Custos

- Administração do Contrato

- Controle de Documentação 


\subsubsection{Ciclo de vida e processos de projeto}

Após o processo de iniciação, o qual formaliza a existência do projeto para a organização definindo os objetivos e nomeando o gerente e a equipe de projeto, é realizada a reunião formal de kick-off meeting (KOM) ${ }^{3}$ com o cliente. Nesta reunião, é apresentada ao cliente, por meio do gerente do projeto, toda a equipe de job leaders ${ }^{4}$ que irá atuar no projeto. São esclarecidos item a item do escopo, seus limites e exclusões, dentre outros assuntos técnicos. Quando da assinatura do contrato, o cliente disponibiliza informações de referência necessárias para elaboração do projeto, estas são analisadas pela equipe e caso se julgue que faltam informações ou que elas estão incompletas, é realizada uma solicitação e esclarecimento ao cliente na reunião de KOM. O processo de planejamento também está presente na reunião de $\mathrm{KOM}$, para definir os padrões a serem utilizados, a periodicidade de reuniões técnicas e gerenciais, critérios de controle e como deverá ser elaborado o projeto. Todas essas informações devem estar presentes em um plano de projeto a ser elaborado pelo gerente e planejador do projeto.

Segundo informado pela Empresa A, durante a execução dos serviços de projeto, soluções técnicas e tomadas de decisões são apresentadas e discutidas com o cliente de forma a ser realizado um projeto com qualidade e que sejam atendidas as expectativas e objetivos do cliente. $\mathrm{O}$ gerente do projeto atua juntamente com o planejamento e equipe técnica, realizando a integração de toda equipe do projeto. É responsável pela tomada de decisões junto ao cliente e por controlar tanto questões técnicas como gerenciais.

Mês a mês são apresentadas ao cliente informações de desempenho do projeto como avanço físico, tendências (prazo), pontos de atenção, controle financeiro e plano de ação (quando há desvios em relação à linha de base estabelecida para o projeto). Este processo de monitoramento e controle é o processo de acompanhamento, revisão e ajustes que fornece à equipe e ao cliente uma compreensão do andamento do projeto, identificando os desvios e pontos de atenção. Ações corretivas, preventivas ou mesmo replanejamento podem ser necessários para atender aos objetivos e desempenho definidos no plano de gestão do projeto.

\footnotetext{
${ }^{3}$ Kick-off meeting: reunião realizada após o aceite e aprovação do cliente para iniciar o desenvolvimento do projeto.

${ }^{4}$ Job leaders: colaboradores designados a liderar a equipe atuante no projeto de sua disciplina. Cada disciplina possui um job leader.
} 
De acordo com prazos estabelecidos no cronograma do projeto, os documentos são enviados ao cliente de maneira formal com guia de remessa para rastreabilidade e o cliente possui a responsabilidade de verificar, realizar comentários e, por fim, aprovar toda a documentação do projeto. No processo de encerramento são finalizadas todas as atividades do projeto, é formalizado o aceite dos resultados obtidos e o término oficial do contrato. Para a validação do contrato é realizado um relatório final contendo todas as informações gerenciais do contrato como um todo. Por fim, a equipe é desmobilizada e tem-se então o encerramento do projeto.

\section{Elaboração do Projeto Detalhado}

Quanto à etapa de Detalhamento do Projeto, duas situações foram relatadas pelos entrevistados, sendo suas consequências bastante impactantes em relação aos resultados finais e para a satisfação do cliente. Essas duas situações são descritas a seguir.

\section{Primeira Situação}

Logo após o processo de iniciação, no qual foi definida a equipe, elaborado o termo de abertura e o início de projeto foi oficialmente autorizado, a projetista demandou informações para proceder o desenvolvimento do projeto e essas informações foram disponibilizadas pelo cliente. Este, porém, não havia definido com os fornecedores os principais equipamentos que seriam adquiridos para o empreendimento. Sendo assim, não foi possível enviar à projetista informações reais e confiáveis do tamanho, peso e outras características desses equipamentos. $\mathrm{Na}$ falta de informações exatas, a projetista adotou como premissa para elaboração do projeto (dimensionamento de pátios, por exemplo) a utilização de referências disponíveis em etapas anteriores do projeto.

Já ao término desta etapa de detalhamento, o cliente obteve informações dos fornecedores e as disponibilizou a projetista. Porém, as informações divergiam da premissa adotada e como resultado foi verificado, por exemplo, o aumento de $20 \%$ do comprimento do pátio de minério, o que ocasionou uma mudança de escopo, retrabalho, aumento de prazo, aumento de custo, entre outros aspectos negativos. 
Nesta situação apresentada, é possível observar que os dados de entrada para o desenvolvimento do projeto não eram confiáveis. Com o intuito de cumprir o prazo e contrato com cliente, a projetista utilizou as informações disponíveis e, ao receber as informações reais, foi verificado que um projeto inconsistente com a realidade estava sendo elaborado. Para reverter a situação e obter um projeto com qualidade e confiabilidade, o projeto mudou totalmente seu rumo, gerando retrabalhos e custos adicionais.

\section{Segunda Situação}

Dado por finalizado o processo de iniciação, durante a reunião de kick-off meeting eventuais dúvidas e questionamentos foram discutidos e uma compreensão comum entre as partes (cliente e projetista) em relação ao entendimento do escopo foi obtida. O coordenador do projeto da projetista realizou a tarefa de detalhar o escopo para a equipe, direcionando a cada agente envolvido os serviços a serem realizados. Foi verificado que, naquele momento, não havia recursos humanos disponíveis na empresa para a realização do projeto de drenagem. Considerando o curto prazo estabelecido e como ação de mitigação de críticas realizadas pelo cliente ao projeto básico, o coordenador do projeto tomou a decisão de contratar uma consultoria técnica externa para a elaboração desse projeto de drenagem.

Conforme relato do gerente do projeto, ao final do processo de execução do projeto de drenagem, o consultor externo elaborou os documentos de projeto e os disponibilizou à projetista na data limite de sua entrega ao cliente. Para atender ao prazo contratual, o coordenador do projeto decidiu não realizar as verificações de interferências com as outras disciplinas. O projeto foi entregue ao cliente sem mesmo ter sido realizada uma análise crítica. Ou seja, o processo de monitoramento e controle não foi realizado de forma adequada, pois não houve controle do escopo e controle da qualidade do projeto.

Alguns documentos de projeto foram comentados e aprovados pelo cliente e outros foram aprovados pela própria projetista por decurso de prazo (no plano de gestão do projeto é informado que, expirado o prazo estabelecido de envio de comentários pelo cliente, a projetista tem o direito de aprovar seus documentos por decurso de prazo). Sendo assim, foi realizado o processo de encerramento do projeto, por meio do aceite do cliente e finalização de todas as atividades do projeto. 


\subsubsection{Gestão de Riscos}

Com base nas informações das entrevistas realizadas e verificação das documentações do estudo de caso, é possível afirmar que não foi elaborada nenhuma análise de risco quanto à aquisição de serviços externos. Esta análise deveria ser realizada com uso do planejamento da gestão de riscos, e após esse processo os possíveis riscos referentes à contratação de terceiros para realização de parte do escopo do projeto deveriam ser identificados. Riscos relacionados a prazo e qualidade seriam exemplos de riscos a serem analisados, monitorados e controlados a fim de garantir os objetivos do cliente quanto ao trabalho realizado por uma equipe terceirizada.

\subsubsection{Gestão da Informação e Comunicação}

Uma das principais atividades no início de um projeto é a busca da informação. Tal busca tem origem na necessidade de se reduzirem as incertezas quanto aos rumos do projeto. O cliente deve definir suas necessidades e requisitos transmitindo-os à projetista juntamente com informações de referência confiáveis, pois elas serão utilizadas como dados de entrada para a elaboração do projeto.

No presente estudo de caso, no que se refere a informações disponibilizadas à projetista antes do processo de execução, é possível observar que tais informações possuíam um grau de incerteza muito grande, somando-se à falta de comprometimento do cliente no que diz respeito à qualidade da informação, o que ocasionou graves prejuízos. De acordo com a literatura estudada, os dados iniciais para o desenvolvimento do projeto (coleta e entrada de informações) definem uma etapa do processo da gestão de informação de grande relevância; esses dados devem ser confiáveis para que o projeto possa atingir o maior grau de qualidade possível, diminuindo riscos em relação a qualidade, prazos e aumento de custos. Uma maior atenção teria sido necessária quanto à qualidade de informações enviadas à projetista no início do projeto.

\subsubsection{Gestão da Qualidade}

Não foi incluída na gestão do projeto a avaliação, verificação e controle de processo para projetos elaborados por terceiros. Entregas parciais dos projetos e verificação técnica do 
trabalho desenvolvido pela consultoria externa poderiam ter auxiliado a minimizar os riscos, reduzir custos ou prazos e atender aos objetivos do cliente quanto à qualidade do projeto.

\subsubsection{Gestão do Conhecimento}

Não foi verificado o uso de ferramentas para a gestão do conhecimento, o que ocasiona uma falta de controle e impossibilita criar um banco de dados de conhecimento gerado na organização. No caso estudado, lições aprendidas quanto à contratação de serviços de terceiros seriam inputs para este banco de dados. O conhecimento gerado, identificado e organizado tende a agregar valor à organização e a seus projetos, bem como auxiliar no alcance de suas metas e objetivos.

\subsubsection{Relação com os agentes de produção (execução)}

Após o processo de encerramento do projeto, a projetista foi contratada pela gerenciadora para prestação de serviços de Assistência Técnica à Obra (ATO). Por conta deste contrato, colaboradores da empresa passaram dois meses na obra realizando alterações de projeto.

Graves problemas iniciaram-se seis meses após a entrega e encerramento do projeto detalhado (na execução dos serviços de movimento de terra). Surgiram trincas (Figuras 23 e 24) e os platôs terraplenados iniciaram um processo de escorregamento (Figuras 25 e 26).

Figuras 23 e 24: Trincas - Estudo de Caso 1
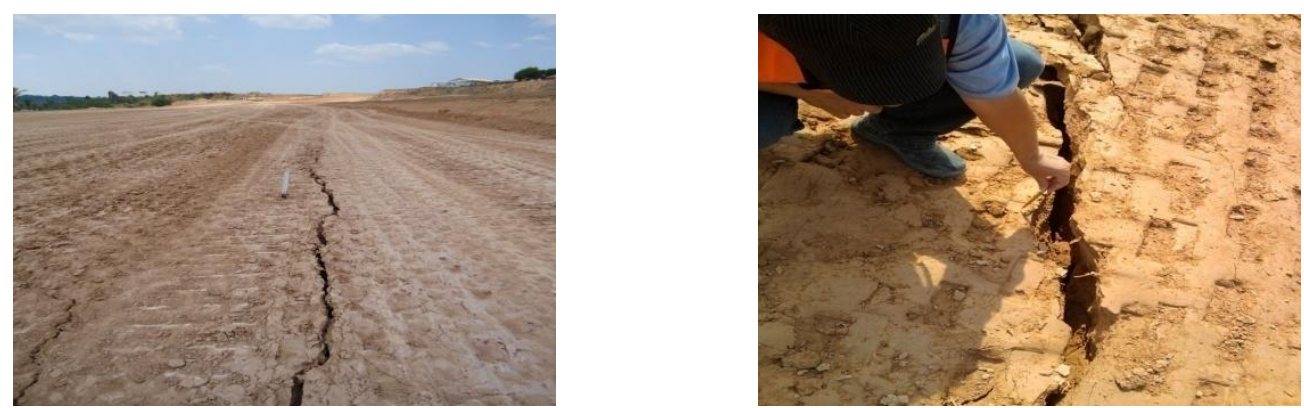

Fonte: Dados de Pesquisa 
Figuras 25 e 26: Escorregamento dos platôs - Estudo de Caso 1
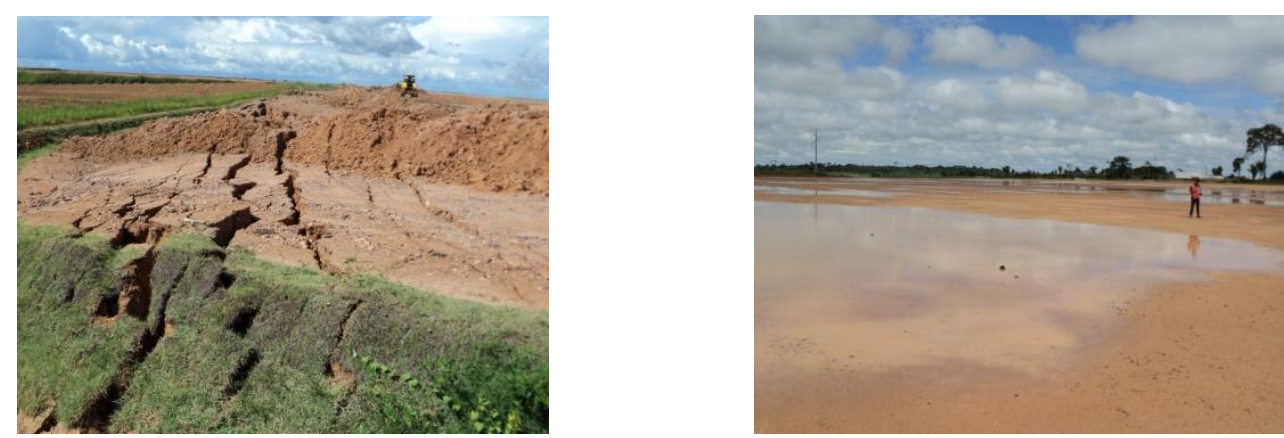

Fonte: Dados de Pesquisa

Constatado o problema, o cliente acionou a projetista e esta contratou um consultor externo (Eng ${ }^{\circ}$ Geólogo Geotécnico) para a realização de análises e investigações. Por meio do relatório elaborado e entregue ao cliente constatou-se que a sondagem foi realizada em período de seca (a projetista utilizou um documento entregue pelo cliente como referência) e que existiam falhas geológicas no terreno. Quanto aos serviços de terraplenagem, os prejuízos ao cliente geraram um custo adicional da ordem de 40 milhões de dólares.

Enquanto o consultor contratado pela projetista realizava as investigações, o cliente juntamente com a gerenciadora procedeu a uma verificação do projeto detalhado entregue pela projetista. Nessa verificação, foram encontrados equívocos nos desenhos de drenagem (aqueles que foram realizados com consultoria técnica contratada pela projetista e que não sofreram nenhum tipo de verificação antes de entregar ao cliente). Como consequências para a projetista foram identificadas:

- Retrabalho - no período de quatro meses um engenheiro e um projetista foram alocados neste projeto realizando análises e correções dos desenhos;

- O prejuízo em relação ao custo do projeto para a projetista equivale a aproximadamente $20 \%$ do valor total do contrato;

- Redução de credibilidade perante o cliente; 
- Desmotivação dos colaboradores.

Tanto na primeira quanto na segunda situação, no que se refere a informações disponibilizadas à projetista antes do processo de execução, é possível observar que estas informações possuíam um grau de incerteza muito grande e houve falta de comprometimento do cliente no que diz respeito à qualidade da informação, o que ocasionou prejuízos. De acordo com a literatura estudada, os dados iniciais para o desenvolvimento do projeto (coleta / entrada de informações) constituem uma etapa do processo da gestão de informação de grande relevância e estas informações necessitam ser confiáveis para que o projeto possa atingir o maior grau de qualidade possível, diminuindo riscos em relação a atrasos e aumento de custos. Uma maior atenção é necessária quanto à qualidade de informações enviadas à projetista nessa etapa; por outro lado, a projetista deveria ter analisado criticamente as informações recebidas, evitando incorrer em riscos desnecessários.

A projetista, igualmente, a partir do momento que identifica a necessidade de aquisições de serviços externos necessita elaborar uma análise de riscos em relação principalmente ao prazo e qualidade. Não foi incluída na gestão do projeto a avaliação, verificação e controle de processo e projetos elaborados por terceiros, conforme proposto por Melhado et al. (2005). Com o aumento dos agentes envolvidos, o fluxo de informações se torna mais complexo e a integração entre os projetos gerados, a compatibilização e análise crítica necessitam ser previstos no processo de projeto e acompanhados durante todo o seu desenvolvimento. Entregas parciais dos projetos, diligenciamento e verificação técnica do trabalho desenvolvido pela consultoria externa poderiam minimizar os riscos, reduzir custos ou prazos e atender aos objetivos do cliente quanto à qualidade do projeto.

\subsection{EMPRESA A - ESTUDO DE CASO 2}

\subsubsection{Caracterização do Empreendimento}

Trata-se do projeto de ampliação de uma Fábrica, compreendendo a realização de Projeto Básico e Detalhado. A fábrica inclui um total de três unidades de produção de cosméticos, fragrâncias e produtos de higiene pessoal. 
As salas de produção da fábrica levam nome das bacias hidrográficas brasileiras, sendo que cada uma delas tem especialidade na produção de determinados produtos. Os projetos básico e detalhado possuem perspectiva da elaboração de novos estudos e/ou ampliações de edifícios, áreas de produção, envase, embalagem e utilidades existentes no site, a partir de projeto conceitual consolidado. Na Figura 27 é apresentada a planta geral do empreendimento.

Figura 27 - Planta geral do empreendimento - Estudo de Caso 2

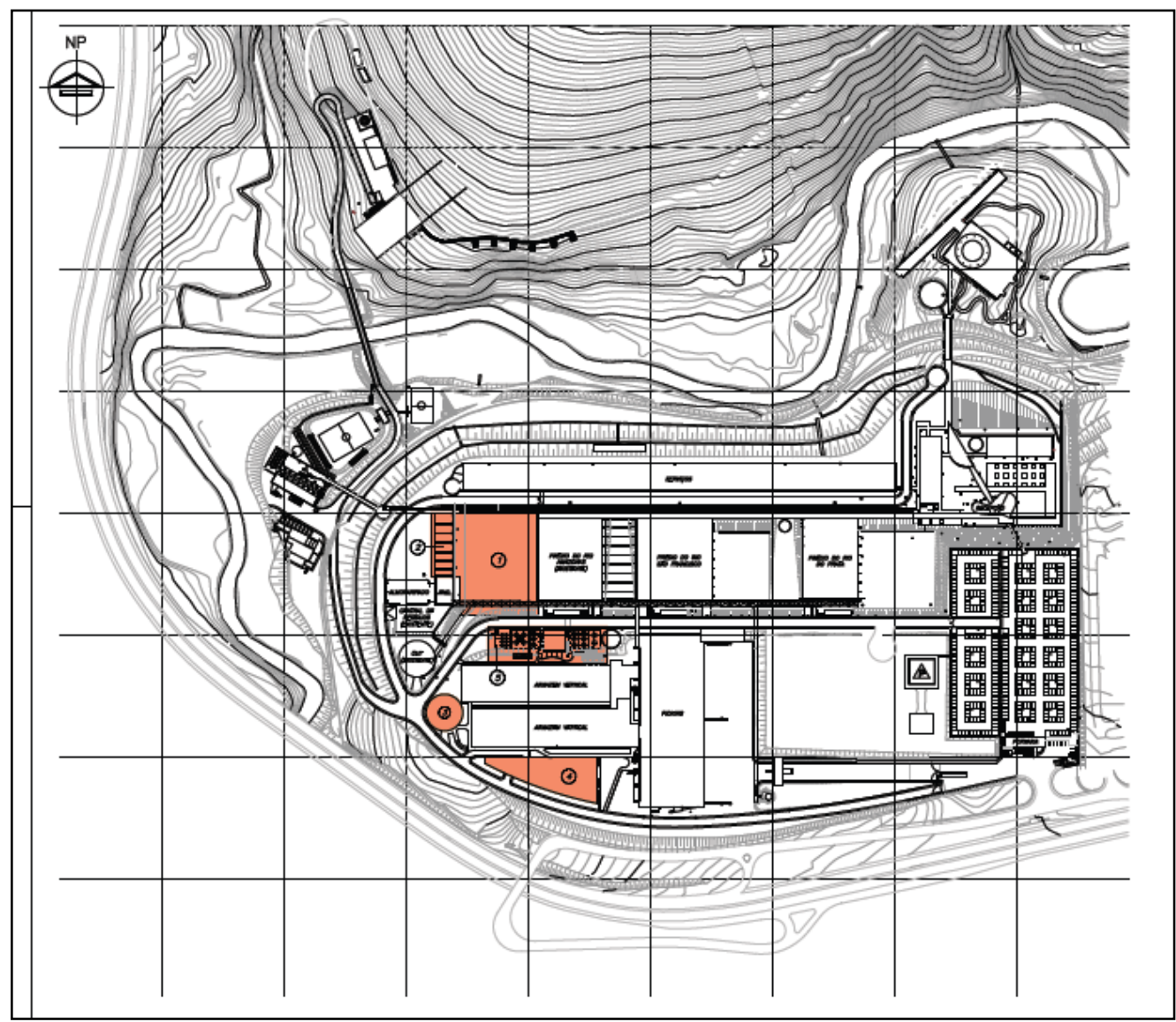

Fonte: Dados de pesquisa

\subsubsection{Escopo do Projeto}

Novos estudos e/ou ampliações de edifícios, áreas de produção, envase, embalagem e utilidades existentes no site, a partir de projeto conceitual consolidado pelo cliente, 
produzindo documentos de projeto (desenhos, memoriais, planilhas de quantitativos) na forma de projeto básico e detalhado dos seguintes edifícios e/ou áreas do site:

1- Implantação geral do site com áreas ampliadas, acrescidas e seu relacionamento c/ o entorno;

2- Subestação Elétrica específica para a Nova Fábrica;

3- Área Dos Vestiários;

4- Laboratórios de Qualidade por Tecnologia;

5- Laboratório Shelf Life;

6- Área de Utilidades;

7- Área de Tancagem de Matérias Primas e Inflamáveis;

8- Ampliação da Fábrica em 100\% do espaço disponível na 2ª Fase;

9- Novo Pipe Rack para distribuição de todas as utilidades às áreas que serão ampliadas;

10- Todas as Utilidades necessárias para implantação do projeto de ampliação da Fábrica: poços artesianos, estação de tratamento de água, caixa central de distribuição de água, estações de produção de água purificada, estação de tratamento de efluentes, caldeiras, central de água gelada processo e central de água gelada (HVAC), inclusive com automação, ar comprimido (isento de óleo), rede de vácuo, rede de combate de incêndio, central de resíduos sólidos e subestação da fábrica; automação de processos e de utilidades incluída;

11- Passarela de Interligação entre Prédio de Engenharia e Ampliação.

Para a prestação dos serviços definidos, o valor estimado do projeto era de $\mathrm{R} \$ 3.598 .182,78$ (três milhões, quinhentos e noventa e oito mil, cento e oitenta e dois reais e setenta e oito centavos), com o prazo estimado de cinco meses e 27 mil horas de engenharia. 
Segundo relato do gerente de projetos, o contrato apresentou uma quantidade significativa de adicional de escopo (MO) somando um valor de mais de 1,5 milhão de reais, ou seja, aproximadamente $43 \%$ do valor do contrato original.

Porém, de todos os itens levantados pela projetista e apresentados pelo cliente, grande parte não foi aprovada e, consequentemente, não foi realizada. Apresenta-se no Quadro 4 uma relação das modificações de escopo solicitadas pela projetista, sendo que, das 19 solicitações, apenas oito foram aprovadas pelo cliente e realizadas pela projetista.

Quadro 4 - Solicitações de alteração de escopo - Caso 2

\begin{tabular}{|l|l|c|}
\hline Número & Descrição & Aprovado \\
\hline MO-001 & Novo projeto conceitual da Central de Resíduos & Sim \\
\hline MO-002 & Levantamento de diversas interferencias & Sim \\
\hline MO-003 & Muro de arrimo/subestação & Sim \\
\hline MO-004 & Estudo de vapor & Não \\
\hline MO-005 & Gerenciamento do estaqueamento & Sim \\
\hline MO-006 & Água Potável & Sim \\
\hline MO-007 & Infra seca CA/CFTV & Sim \\
\hline MO-008 & Elevador/Escada Man. & Sim \\
\hline MO-009 & Reavaliação do sistema de água gelada & Não \\
\hline MO-010 & Empreiterópolis & Não \\
\hline MO-011 & Instalação da instrumentação dos RA's & Não \\
\hline MO-012 & Novos tanques de Lauril & Não \\
\hline MO-013 & Inclusão medidores de vazão pontos de água potável & Não \\
\hline MO-014 & Alterações gerais (Hazop, PIG nas linhas RE/RA,....) & Não \\
\hline MO-015 & Adaptação de Projeto para FASE 1 & Não \\
\hline MO-016 & Tanque de contato para Osmose Reversa & Não \\
\hline MO-017 & Folha de dados para Câmara Fria & Não \\
\hline MO-018 & Instalação de novos No-breaks na Fábrica & Sim \\
\hline MO-019 & Alteração linha de PW & Não \\
\hline
\end{tabular}




\subsubsection{Agentes Envolvidos e Organograma do Empreendimento}

Foram identificados como principais agentes do empreendimento:

- Cliente: composto por gerente de projeto, um arquiteto e um colaborador da manutenção.

- Projetista: com estrutura organizacional matricial (mesma estrutura do estudo de caso 1), tendo a participação da coordenação de projetos e planejamento na área de gestão e corpo técnico formado pelas disciplinas de diversas especialidades.

- Gerenciadora: contratada pelo cliente, sendo constituída por colaborador da projetista.

- Construtora / Montadora: contratadas diretamente pelo cliente para execução do empreendimento. A projetista não possuía comunicação direta com a construtora / montadora.

Os organogramas que mostram as relações entre todos os agentes estão representados nas Figuras 28 e 29.

Figura 28 - Organograma - Fase Projeto - Estudo de Caso 2

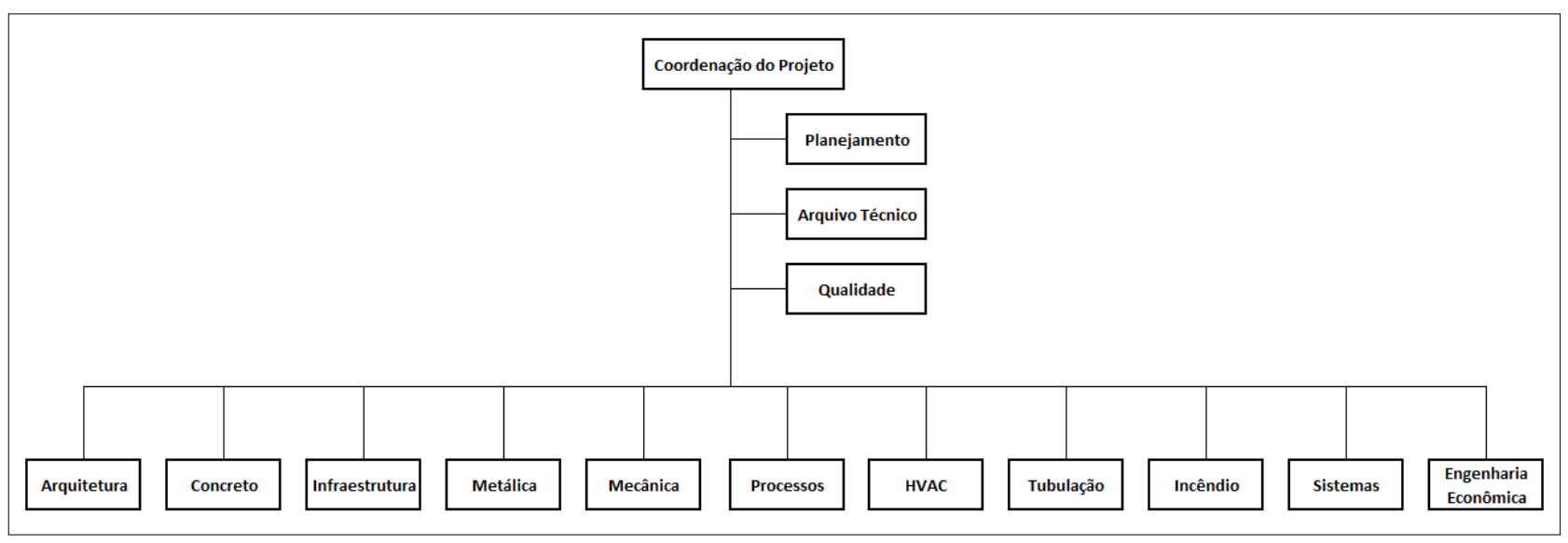

Fonte: Dados de Pesquisa 
Figura 29 - Organograma - Fase Obra - Estudo de Caso 2

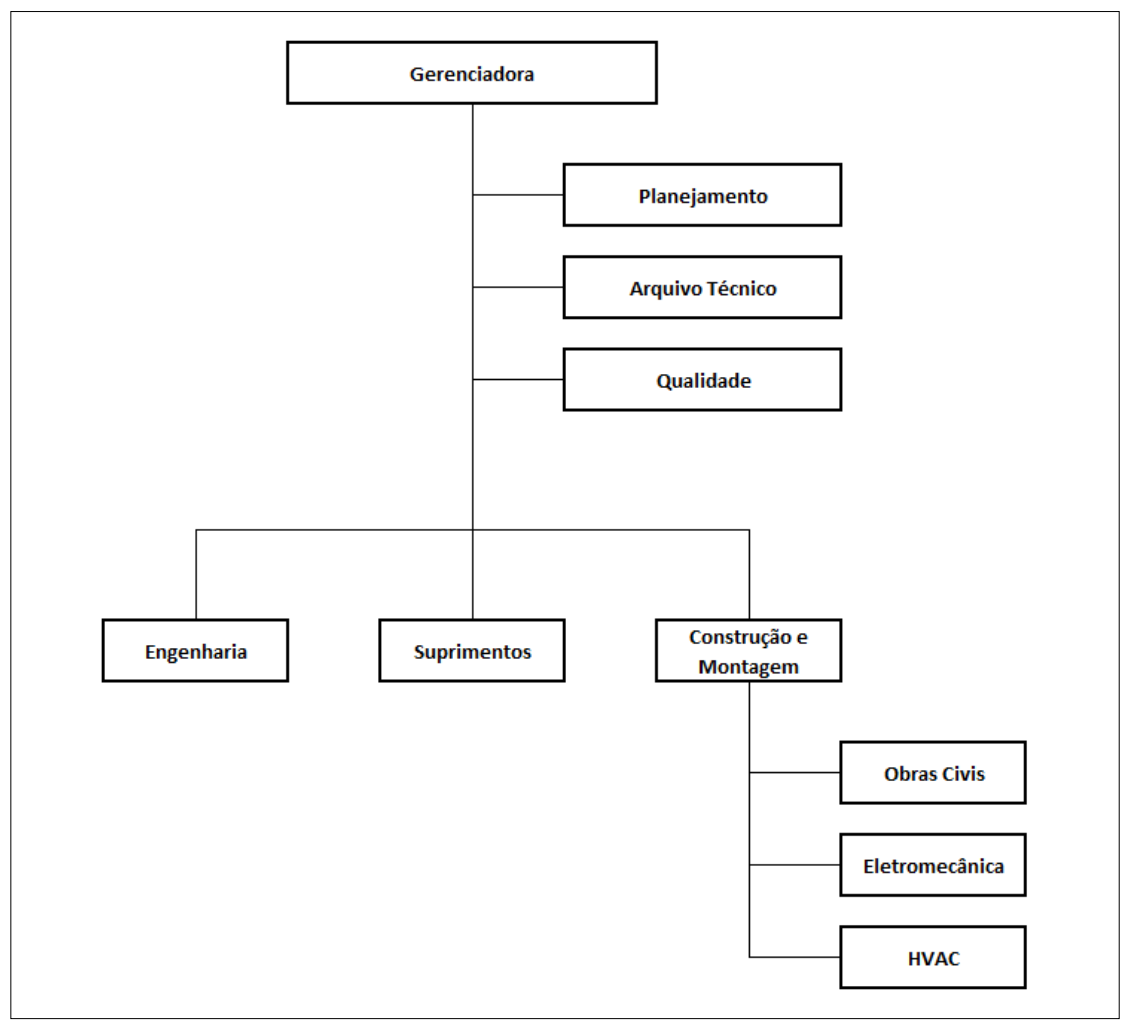

Fonte: Dados de Pesquisa

\subsubsection{Ciclo de vida e processos de projeto}

O estudo de caso 2 pertence à Empresa A e o processo de projeto realizado para esse estudo de caso é o mesmo descrito no estudo de caso 1 (item 3.2.5).

\section{Elaboração dos Projetos Básico e Detalhado}

Em 2011, a projetista foi contratada para desenvolver o projeto básico e detalhado, ou seja, a execução do mesmo ocorreu em duas fases e houve a participação das disciplinas: arquitetura, estrutura de concreto, infraestrutura, estrutura metálica, mecânica, HVAC, processo químico, tubulação, sistema de combate a incêndio, sistemas de engenharia e engenharia econômica. 
Este foi o primeiro projeto desenvolvido na empresa em questão em modelagem 3D utilizando o software "Revit". A projetista não possuía know-how do software (nem em BIM) e foi um dos motivos o qual gerou inúmeras dificuldades ao longo da execução do projeto.

A adoção de conceitos de sustentabilidade no projeto fazia parte do escopo, com objetivo de obter a certificação LEED (nível GOLD). Um dos focos principais era o projeto de iluminação em LED e zenital. Também se destacam o desenvolvimento dos projetos de infraestrutura para aquecimento solar e sistema a vácuo utilizado nos sanitários.

A equalização das propostas técnicas para execução da obra também foi parte do escopo da projetista, assim como a elaboração de estimativas de custos (CAPEX ${ }^{5}$ ).

Conforme relatado pelos entrevistados, foram muitas as dificuldades encontradas ao longo do desenvolvimento do projeto.

Muitas alterações na entrega do projeto básico impactaram diretamente os prazos contratuais. Foi realizada uma reunião para apresentação de todo projeto na entrega oficial do básico, com a participação do gerente que iria liderar a fábrica, pessoal do laboratório e manutenção, os quais não participaram da elaboração do projeto e somente estiveram presentes a essa reunião. Foram solicitadas grandes alterações como, por exemplo, a modificação de todo layout da Central de Resíduos Sólidos, a qual foi registrada em ata de reunião da seguinte forma: "Foi discutido que o layout interno não será o do projeto conceitual, tampouco está definido. Existe um estudo do cliente para este layout mas ele ainda está sendo revisto". Também foi entregue um layout da área de microbiologia (Microbiologia / Shelf Life) com uma série de considerações que divergiam das premissas e informações de referência enviadas à projetista no inicio do projeto. Todas as alterações solicitadas pelo cliente foram registradas e tratadas como MO’s (modificação de objeto), porém nem todas foram aprovadas pelo cliente.

A definição de processo, balanço de massa e utilidades são exemplos de informações necessárias às outras disciplinas para execução do projeto, ou seja, muitas dessas informações

\footnotetext{
${ }^{5}$ CAPEX: sigla da expressão inglesa capital expenditure, que significa o investimento necessário para aquisição de bens, no caso, do empreendimento.
} 
são essenciais para as atividades sucessoras a elas. Porém, conforme relatado pelo coordenador de projeto, houve muito atraso nas definições de dados importantes de processos (reatores), que são informações de referência enviadas pelo cliente. Também houve atraso na entrega de especificação dos tanques de matéria prima, dimensionamento de tubulações e definição de bombas, o que impactou as disciplinas de mecânica, tubulação e a elaboração dos próprios fluxogramas do processo químico.

O cliente não especificou antecipadamente os equipamentos do empreendimento com os fornecedores e, sendo assim, não foi possível enviar à projetista informações reais e confiáveis do tamanho, peso e outras características dos equipamentos. $\mathrm{Na}$ falta de informações exatas, o cliente solicitou à projetista que utilizasse dados de catálogos de equipamentos que ele disponibilizou.

A projetista não tinha know-how em projetos de sistemas hidrossanitários a vácuo, deixando indefinida a especialidade que desenvolveria o projeto (tubulação ou infraestrutura). Por pressão do cliente devido ao atraso no desenvolvimento desse projeto, a projetista subcontratou sua elaboração.

Não ficou claro o motivo, porém o cliente decidiu que, quando houvesse um avanço de $70 \%$ do projeto (detalhamento bem avançado) iniciaria a execução das obras em etapas. A projetista realizou um estudo e foi concluído que haveria grandes impactos caso se realizasse o projeto em fases e, então, ao final, o cliente desistiu de assumir essa alteração em projeto; porém, na execução, foi utilizado esse método de etapas.

\subsubsection{Gestão de Riscos}

A projetista não realizou análise de risco quanto à falta de conhecimento e primeira experiência na elaboração de projeto utilizando o sistema BIM. Embora a utilização do sistema tenha sido uma exigência do cliente, o coordenador do projeto, com apoio da equipe, deveria ter identificado os riscos dessa exigência contratual, de modo a serem analisados, monitorados e controlados durante toda a fase de projeto. Retrabalhos, diminuição da produtividade da equipe pela falta de conhecimento no uso do software "Revit", maior tempo de execução das atividades devido à cultura de projetar em "2D" e não "BIM" foram motivo 
de atrasos que poderiam ter sido evitados com a identificação dos riscos que contribuíram para esses resultados negativos.

\subsubsection{Gestão da Informação e Comunicação (Interface Projeto - Obra)}

No início da obra houve muita pressão por parte do cliente, devido à execução de serviços de fundações em período de chuvas. Havia colaboradores da projetista fazendo a gestão da obra e da interface projeto-obra. O fato de uma equipe da própria projetista fazer a gestão da obra e da interface projeto-obra facilitou a comunicação, possíveis adequações e revisões necessárias no projeto.

Os projetos sofreram compatibilização com a execução em andamento devido ao atraso das entregas pela projetista. Os colaboradores permaneceram na obra por aproximadamente três meses, até o final do contrato.

Na licitação feita para a execução das obras, a projetista ganhou o contrato da gestão do empreendimento, e a engenharia realizou a equalização técnica das construtoras junto ao cliente sendo uma construtora aprovada ao final. Uma das concorrentes, a qual não concordou com o processo e forma de equalização entrou com recurso na ouvidoria criticando o critério adotado para seleção de fornecedor. Devido a esse motivo, foi reaberto o processo de licitação e uma nova equalização técnica teve que ser realizada gerando impactos de prazo para inicio da construção, além de custos não previstos com nova equalização técnica pela projetista. $\mathrm{Na}$ prática, isso ajudou a projetista, dando mais prazo para ela terminar o projeto, antes do início das obras.

O cliente não tinha controle interno de recebimento de projetos efetivo. A entrega dos projetos tanto era feita via portal web de transferência de arquivos (webtransfer), quanto por entrega de DVDs ou o cliente solicitava cópias físicas ao arquivo técnico da projetista. As várias formas de recebimento de projetos propiciaram uma utilização de revisões canceladas na obra.

Adicionalmente, muitas alterações na liderança, tanto no corpo técnico como na gestão por parte da projetista, dificultaram a gestão da comunicação no projeto.

Até um avanço de 50\% da execução do detalhamento não havia uma rotina de reuniões com o cliente, apenas internas. A essa época, foi decidido realizar reuniões semanais com a 
participação do cliente para que houvesse uma maior interação entre as partes e essas reuniões auxiliaram e muito nas tratativas de pendências do projeto (principalmente assuntos relacionados aos equipamentos, que o cliente ainda não havia adquirido). Com a participação do cliente eram acordadas e adotadas premissas para elaboração do projeto. Da parte do cliente participavam o gestor do projeto, uma arquiteta e um colaborador de manutenção.

Não havia agilidade por parte do cliente no envio de informações de referência, como dados de processo. A equipe do cliente era reduzida e não continha todas as especialidades (gerente de projeto / arquitetura / manutenção) e quando eram necessárias informações do processo industrial, era preciso contatar pessoal externo ao projeto, que muitas vezes não tinha disponibilidade e, assim, as informações demoravam a chegar à projetista.

\subsubsection{Gestão da Qualidade}

Algumas deficiências no processo de projeto no uso da "plataforma BIM" impactaram a elaboração das atividades e, consequentemente, a qualidade do projeto:

- Inexperiência no desenvolvimento de modelos tridimensionais;

- Deficiência no esclarecimento de escopo do nível de detalhamento do projeto a partir das reuniões iniciais (KOM);

- Nível de detalhamento e requisitos para o modelo BIM.

Com base no depoimento de colaboradores da empresa projetista, as dificuldades que foram apontadas tiveram origem nos seguintes fatores:

- Falta de tempo e planejamento para implantação da tecnologia - estas foram as maiores dificuldades apontadas pela empresa. No caso da projetista em questão ainda há um agravante, pois não foi contratada uma consultoria técnica para implantação, dado que não existia a cultura na empresa.

- Carência de profissionais especializados - há poucos profissionais com conhecimento em modelagem de informação da construção (BIM), o que levou a empresa a oferecer treinamento, porém este foi oferecido apenas a um grupo específico de colaboradores. 
- Resistência a mudanças pela equipe - trabalhar com BIM exige não só o aprendizado das ferramentas necessárias, mas uma nova forma de pensar e um novo processo de projeto. $\mathrm{Na}$ empresa em questão, houve uma maior resistência dos colaboradores mais antigos e com maior tempo de experiência.

- Falta de Infraestrutura de TI - os softwares utilizados pela empresa, como o REVIT necessitam de máquinas com uma capacidade de processamento muito superior a daquelas que eram anteriormente utilizadas apenas para CAD. A troca de equipamento era necessária para que se tivesse um melhor desempenho, porém a falta de equipamentos disponíveis na empresa gerou atrasos na elaboração de atividades previstas.

- Deficiências do próprio Software (REVIT) - foi detectada falta de eficiência quanto à renderização e problemas na confecção de escadas com dois patamares, conforme ilustrado nas Figuras 30 e 31.

- Compatibilidade - a projetista utilizou softwares de diferentes fabricantes para elaboração do projeto nas disciplinas envolvidas, por uma questão política da empresa. Por exemplo, a Arquitetura utilizou REVIT, enquanto a Mecânica utilizou Solid Works e a Tubulação, AutoCad Plant 3D. Dessa forma, foram detectadas dificuldades quanto à compatibilização desses softwares, as quais são mostradas na Figura 32 (a tubulação aparece representada por linhas e não sólidos).

- Adaptação aos padrões brasileiros de construção - a disciplina de arquitetura informou que, para o REVIT, grande parte da biblioteca existe é estrangeira e que em muitos casos é necessária a adaptação aos padrões nacionais.

- Tamanho dos arquivos gerados - os arquivos gerados são bem maiores que os do CAD.

- Gestão - foi verificada falha da projetista quanto à falta de gestão e planejamento das mudanças necessárias no processo de projeto. Trabalhar com BIM exige mudança da cultura de processo de projeto, mudança na qual o planejamento e gestão são fundamentais para que haja sucesso na implantação e consequentemente, para que sejam visíveis os benefícios e vantagens que o BIM pode oferecer. 
Figura 30: Problemas detectados na confecção de escadas com dois patamares - Estudo de Caso 2

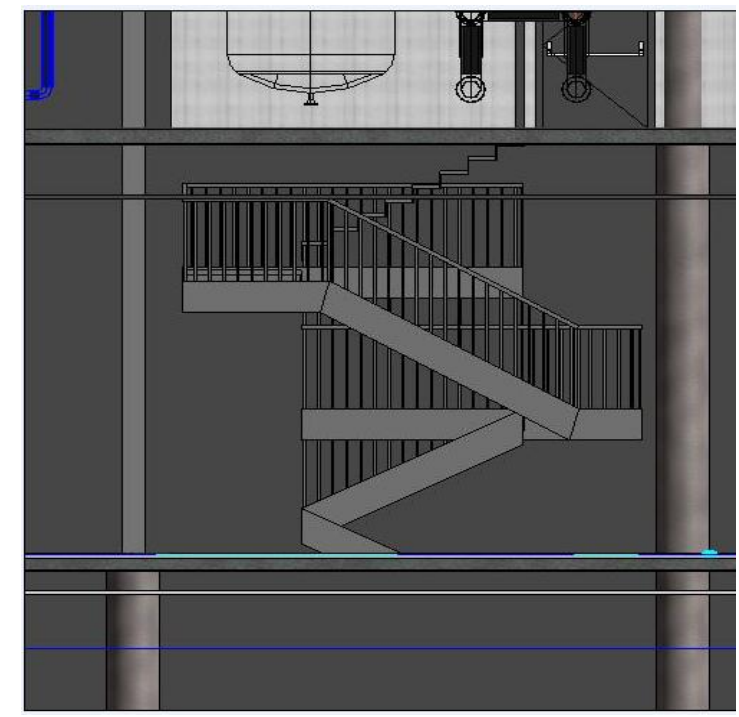

Fonte: Dados da pesquisa

Figura 31: Problemas detectados na confecção de escadas com dois patamares - Estudo de Caso 2

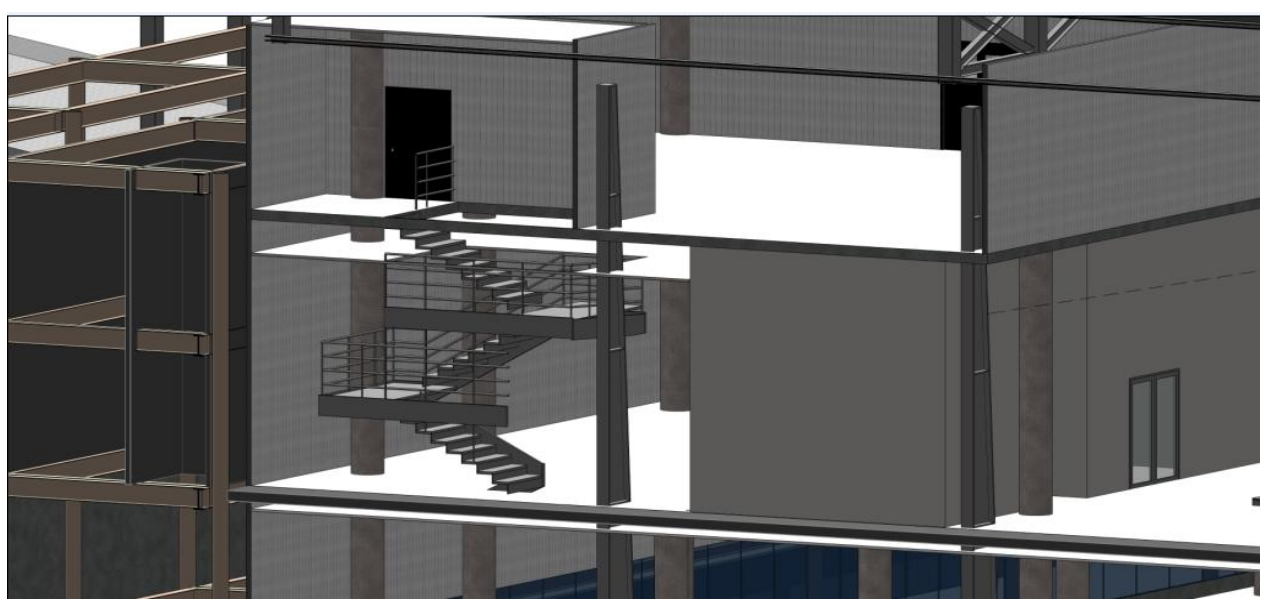

Fonte: Dados da pesquisa 
Figura 32: Problemas de compatibilidade - Estudo de Caso 2

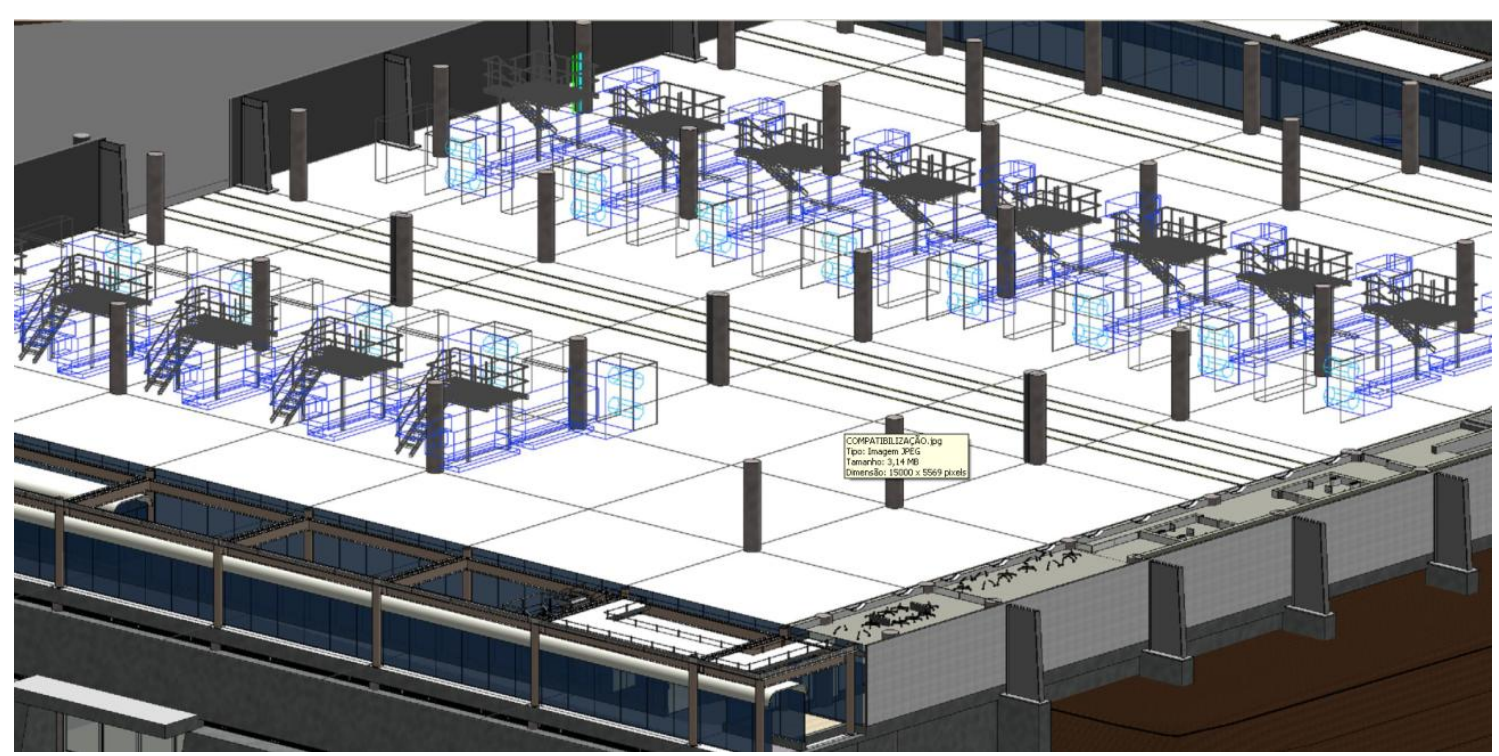

Fonte: Dados da pesquisa

\subsubsection{Gestão do Conhecimento}

Não foi verificado o uso de ferramentas para a gestão do conhecimento, o que ocasiona uma falta de controle e banco de dados de conhecimento gerado na organização. No caso estudado, lições aprendidas quanto à falta de know-how do sistema "BIM" e projeto do sistema hidrossanitário a vácuo seriam exemplos de inputs para este banco de dados. O conhecimento gerado, identificado e organizado tende a agregar valor à organização e auxiliar no alcance de suas metas e objetivos.

Além disso, a rotatividade da equipe da projetista (técnica, gestão, planejamento) dificultou qualquer iniciativa voltada à gestão do conhecimento, uma vez que os colaboradores que acompanharam todo o histórico do projeto desde seu início não criaram um banco de dados organizado. Dessa forma, a rastreabilidade de informações ficou comprometida, levando a uma gestão do conhecimento ineficaz.

\subsubsection{Relação com os agentes de produção (execução)}

As fotos exibidas nas Figuras 33, 34 e 35 mostram as características gerais da obra, no período de sua execução. 
Figura 33: Execução da obra - Estudo de Caso 2

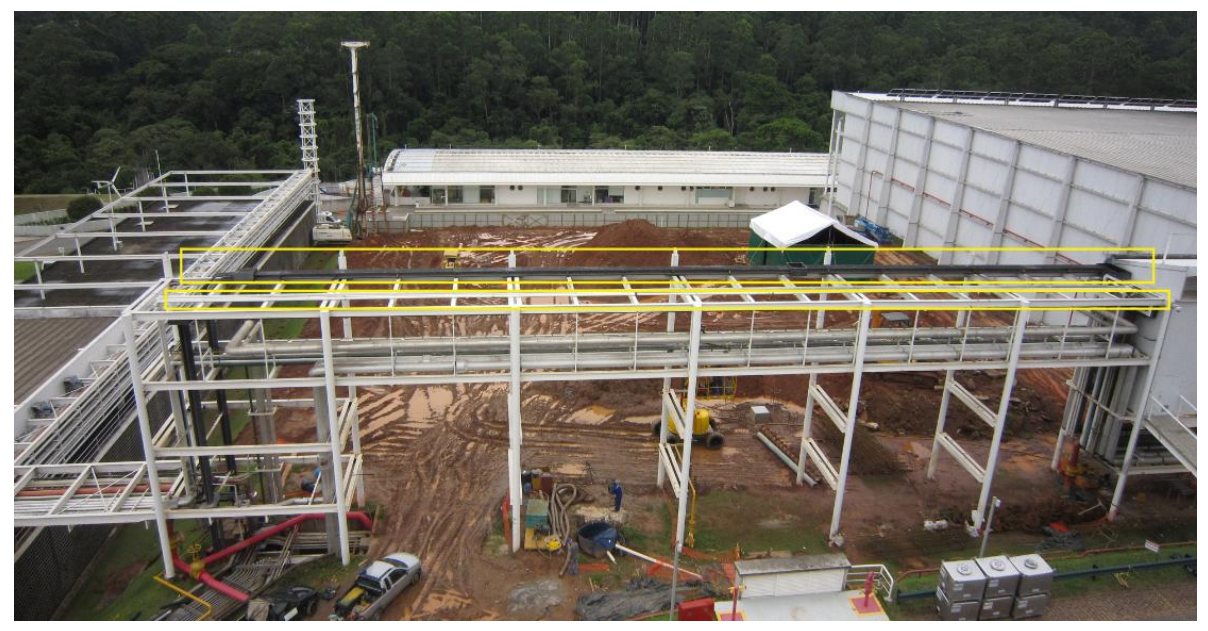

Fonte: Dados da pesquisa

Figura 34: Execução da obra - Estudo de Caso 2

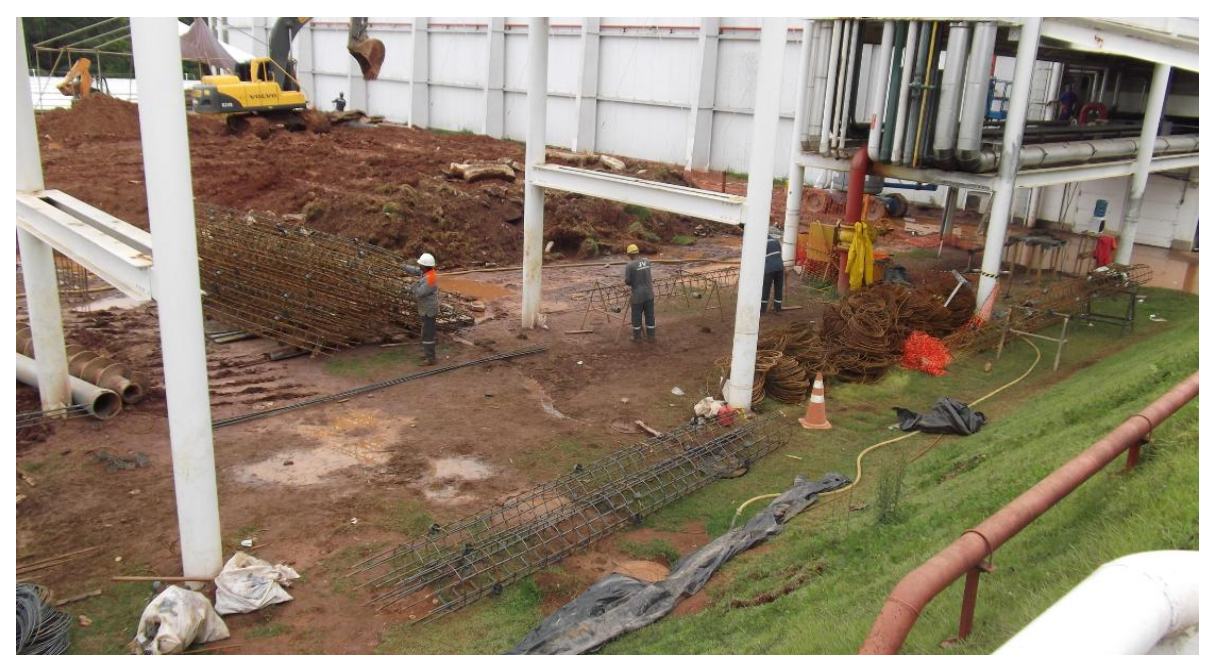

Fonte: Dados da pesquisa 
Figura 35: Execução da obra - Estudo de Caso 2

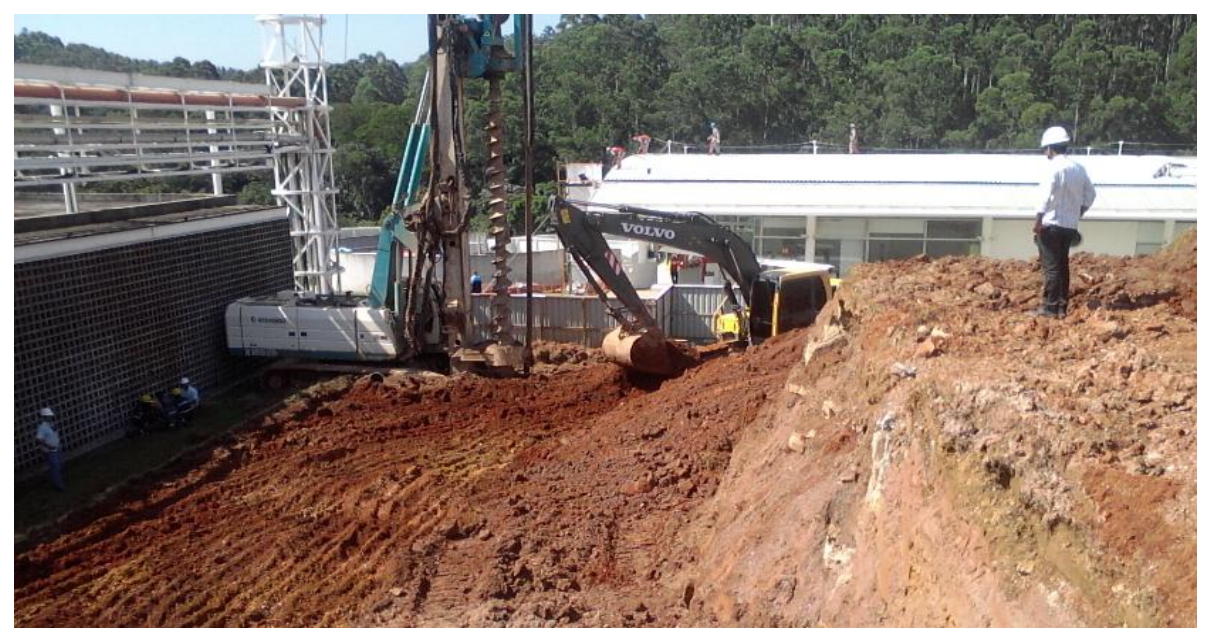

Fonte: Dados da pesquisa

A entrevista realizada com um dos colaboradores da empresa forneceu dados importantes acerca de incidentes e problemas durante a fase de execução das obras, relatados a seguir.

\section{Incidente com tubulação de incêndio}

No dia 24/11/2011, quando o trado fazia a perfuração de uma das estacas, ocorreu o rompimento de uma tubulação em aço a $50 \mathrm{~cm}$ de profundidade, que, segundo informações da empresa terceira responsável pela manutenção, pertence ao sistema de incêndio do empreendimento do cliente (Figura 36). Também houve rompimento de uma tubulação de PVC marrom de água. Logo após o ocorrido, foi acionada a equipe de manutenção do cliente que tomou as medidas cabíveis. Após esta interferência, tomou-se a decisão de interromper as atividades naquele dia. 
Figura 36: Incidente com tubulação de incêndio - Estudo de Caso 2

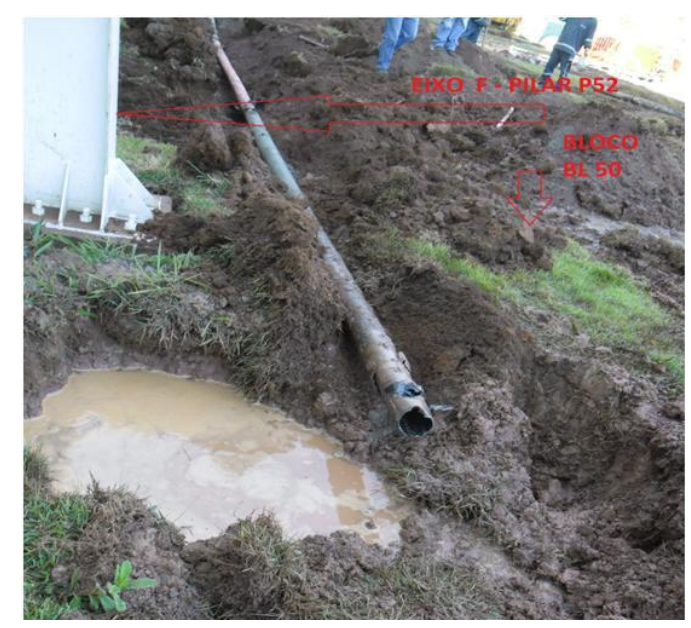

Fonte: Dados da pesquisa

\section{Incidente com um duto de ar condicionado}

No dia seguinte ao incidente relatado acima, o trado que fazia a perfuração das estacas rompeu um duto de ar condicionado de diâmetro estimado de $80 \mathrm{~cm}$ a uma profundidade de $1,80 \mathrm{~m}$ (Figura 37).

Figura 37: Incidente com um duto de ar condicionado - Estudo de Caso 2

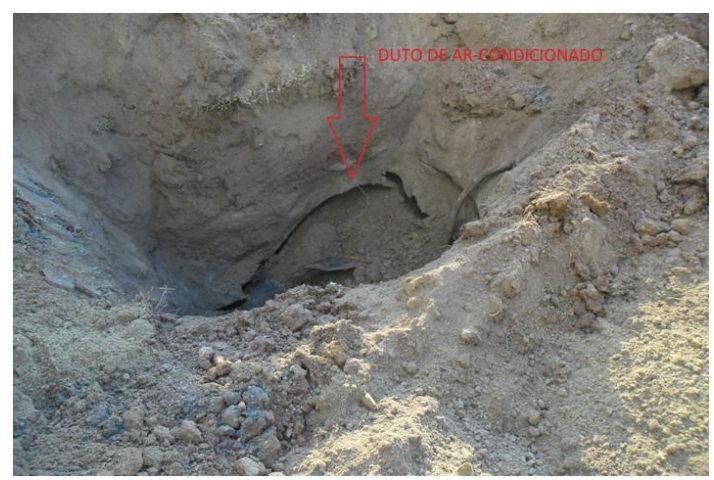

Fonte: Dados da pesquisa 
Foi observado que os incidentes gerados se deveram ao fato de que as posições das instalações representadas no desenho de referência disponibilizado pelo cliente não coincidem com a sua localização física real. No caso do incidente com o duto de ar condicionado, a entrada no platô é feita entre eixos C e D e não entre eixos B e C e sua distância do eixo é menor que a representação gráfica do desenho.

Pelo desenho de referência, não deveria ter havido interferência das estacas com o duto (Figura 38).

Figura 38: Desenho de referência fornecido pelo cliente - Estudo de Caso 2

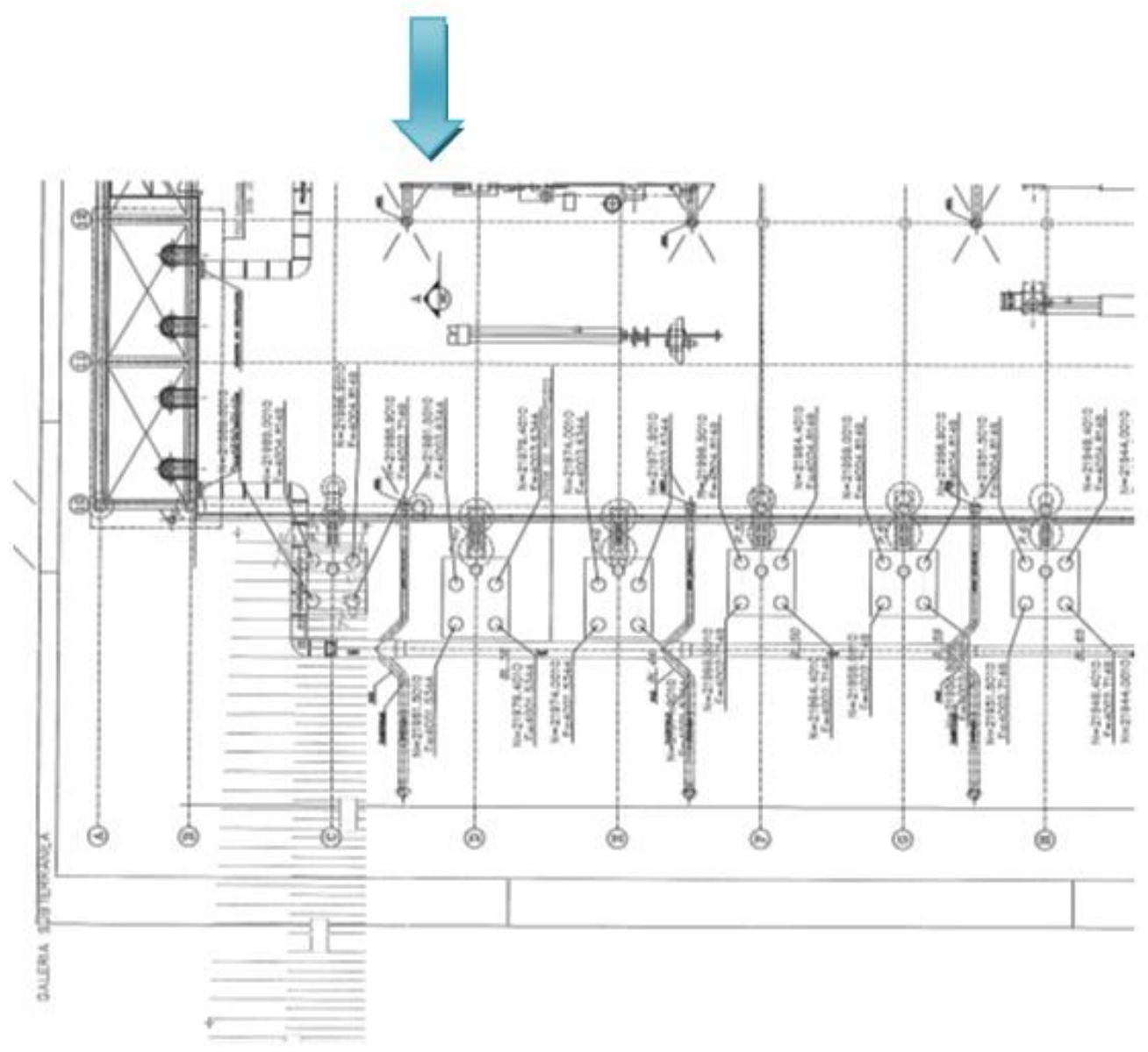

Fonte: Dados de Pesquisa 


\subsection{EMPRESA B - ESTUDO DE CASO 3}

\subsubsection{Caracterização do Empreendimento}

Trata-se do projeto de implantação de uma Unidade de Recuperação de Hidrogênio e construção do Sistema de Enriquecimento de Oxigênio - UHR, em uma refinaria de óleo e gás.

As Unidades de HDT's (hidrotratamento) e HDS's (hidrodessulfurização) geram correntes de gás ácido, com alto teor de hidrogênio:, aproximadamente $85 \%$ de $\mathrm{H}_{2}$. Atualmente, as correntes do HDT's de Diesel são enviadas para uma unidade de DEA (unidade de tratamento de gás combustível com uso de soluções de Di-Etanol-Amina) para remoção do $\mathrm{H}_{2} \mathrm{~S}$ (ácido sulfúrico) e, em seguida, para a rede de gás combustível da refinaria com $5,5 \mathrm{kgf} / \mathrm{cm} 2 \mathrm{de}$ pressão. Devido ao aumento desta corrente, com a entrada em operação das novas unidades de HDS's (nafta craqueada) e HDT’s (nafta de coque e futuro HDT de diesel), será instalada uma Unidade de Recuperação de Hidrogênio (URH). A unidade será composta basicamente de dois sistemas de compressão, PSA, vasos separadores gás/líquido e sistema de Sump. Um compressor elevará a pressão dos gases vindo das DEA's de aproximadamente 5,0 para 23,0 $\mathrm{kgf} / \mathrm{cm}^{2}$, o suficiente para a separação das impurezas (hidrocarbonetos leves) na PSA (pressure swing adsorption - unidade responsável por separar o hidrogênio) e para alimentar o header (distribuidor) de hidrogênio da refinaria. Outro compressor tem por finalidade elevar a pressão das impurezas retidas na PSA aumentando a pressão de 0,2 para 5,5 $\mathrm{kgf} / \mathrm{cm}^{2}$, encaminhando-as para o header de gás combustível. Os vasos separadores têm por finalidade evitar líquido no compressor de carga, PSA e header de gás combustível. No sistema de Sump, o líquido separado (nafta selvagem) será estocado em um vaso e bombeado para as unidades de destilação ou coque.

A Unidade a ser construída terá uma capacidade nominal de carga de $322.000 \mathrm{Nm}^{3} / \mathrm{d}$ e produção estimada de 200.000 Nm³/d de hidrogênio e 122.000 Nm³/d de gás combustível. Na Figura 39 é apresentada a planta geral do empreendimento. 
Figura 39 - Planta geral do empreendimento UHR - Estudo de Caso 3

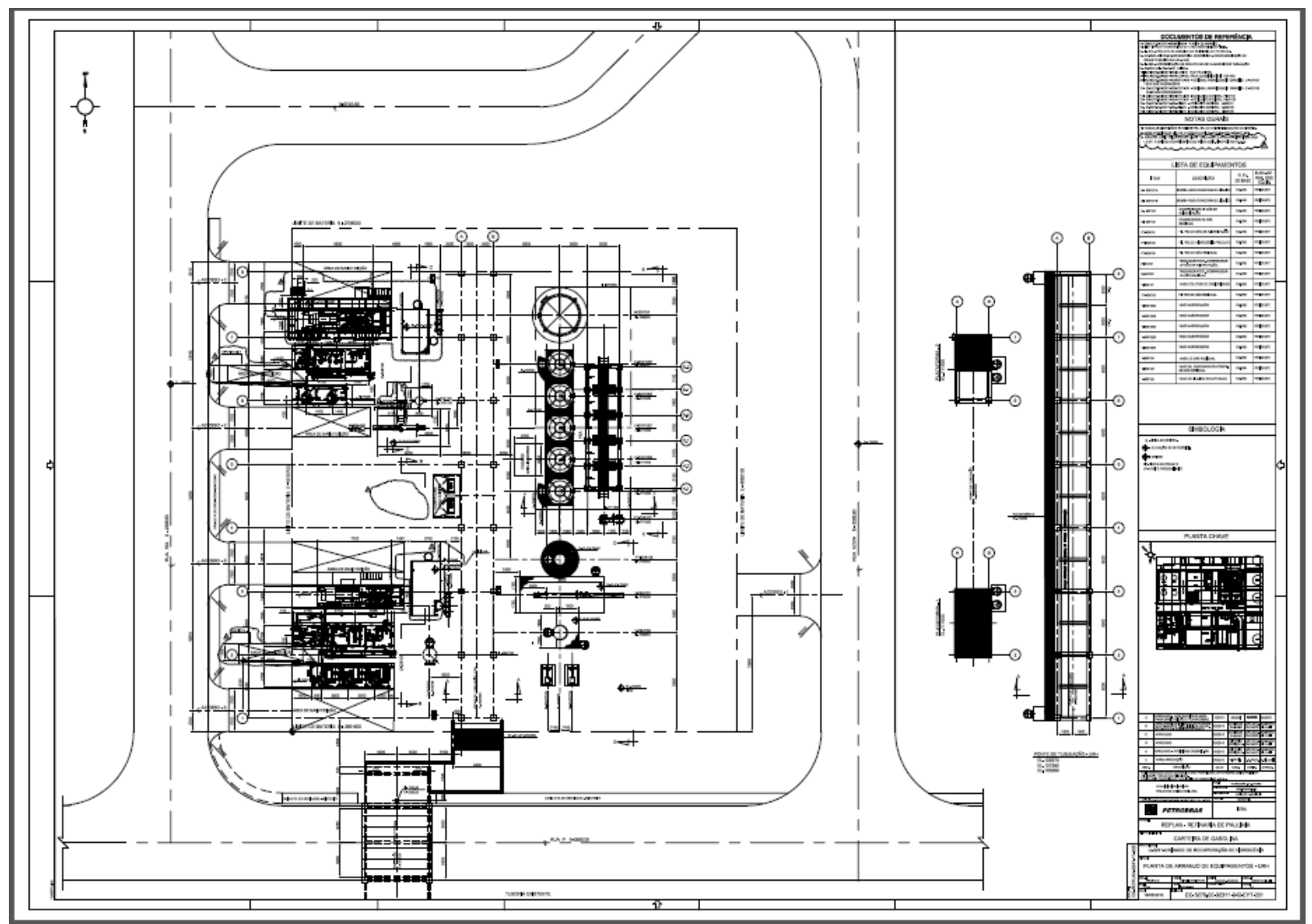

Fonte: Dados de pesquisa

\subsubsection{Escopo do Projeto}

De acordo com a proposta técnico-comercial, fazem parte do escopo contratado os seguintes serviços principais, dentre outros:

\section{Gerenciamento, Planejamento e Controle do Projeto}

- Atividades de Coordenação Técnica e Administrativa; 
- Preparação e acompanhamento dos documentos de planejamento e controle do projeto, englobando as atividades objeto da contratação e relatórios mensais de progresso e andamento dos serviços;

- Gestão da Documentação de Projeto e Controle de Documentos de Fornecedores.

\section{Engenharia Básica}

- Análise de Consistência do Projeto Básico.

\section{Engenharia de Detalhamento}

- Projeto de Detalhamento;

- Elaboração da Maquete Eletrônica;

- Elaboração dos "Data Books" do projeto;

- Geração de informações técnicas necessárias à Construção e Montagem;

- Geração de informações técnicas necessárias ao Comissionamento, Pré-operação e Operação Assistida das Unidades, se solicitado pela contratante.

\section{Assistência Técnica}

- Assistência Técnica em campo para auxílio à Construção e à Montagem, ao Comissionamento, aos Testes e Apoio à Pré-operação e à Operação Assistida da Unidade, em regime de administração.

Para os serviços a preço global de Projeto de Detalhamento os serviços foram contratados por $\mathrm{R} \$$ 3.682.712,80 (três milhões seiscentos e oitenta e dois mil e setecentos e doze reais) compreendendo 28 mil horas de engenharia e prazo previsto de 14 meses.

O valor inicial contratado precisou de aditamentos. Segundo o gerente de projetos, a maioria das alterações de projeto partiu do cliente final e muitas delas ocorreram quando a execução 
em campo já estava concluída. Observe-se que o cliente final e seus representantes (equipe de operação e manutenção) não tiveram uma participação efetiva na fase de projeto.

Muitas mudanças não foram registradas e cobradas como extra do cliente final, pois a construtora não registrou devidamente as premissas adotadas pelo cliente e muitas alterações foram realizadas antes de um aceite formal: a construtora sofreu influências de fiscais e operadores (cliente final) em campo e no contrato era muito claro que as alterações realizadas sem um aceite formal eram consideradas responsabilidade da construtora.

\subsubsection{Agentes Envolvidos e Organograma do Empreendimento}

Para a elaboração dos serviços foi apresentada uma equipe composta por profissionais integrantes do corpo técnico permanente da empresa, mobilizados dentro de um organograma matricial, eventualmente agregando-se consultores externos para assuntos específicos, sempre que necessário.

A equipe, cujo organograma pode ser visto na Figura 40, foi estruturada segundo as principais funções a seguir descritas.

O Diretor do Contrato liderava a estrutura organizacional e promove um canal de comunicação entre a Diretoria da empresa e a Diretoria da Contratante; ele atua preventivamente, detendo informações atualizadas sobre o andamento dos serviços e autorizando toda e qualquer providência que possibilite a melhora ou agilização dos trabalhos.

O Gerente do Projeto tinha sua função relacionada ao desempenho técnico e administrativo do contrato, sendo responsável pela coordenação geral do projeto e por atividades como organização e trâmite de informações, dentre outras.

O Coordenador Técnico tinha como principal função a coordenação das atividades e informações de todas as disciplinas envolvidas e centralização das interfaces entre vários job leaders, agindo de maneira a possibilitar a integração entre as especialidades envolvidas.

O Job Leader ou Supervisor de Disciplina era um profissional com mais de 25 anos de experiência na especialidade, sendo responsável por todas as atividades da disciplina específica. 
O Líder de Disciplina era responsável pela disciplina em uma unidade de projeto, com a finalidade de organizar e centralizar as informações daquela área específica.

O Job Leader de Planejamento e Controle atuava em consonância com a área de planejamento da empresa.

O Job Leader de Documentação era responsável pelo registro e tramitação dos documentos do projeto e a operação do sistema de gestão eletrônica de documentos.

O Supervisor de Qualidade era responsável pela auditoria e por aferir se os requisitos de qualidade estavam sendo corretamente atendidos no contrato, envolvendo desde o início da contratação até a emissão final de documentos, sendo que o plano de qualidade era elaborado pelo departamento de garantia de qualidade da empresa. 
Figura 40 - Organograma do Estudo de Caso - Estudo de Caso 3

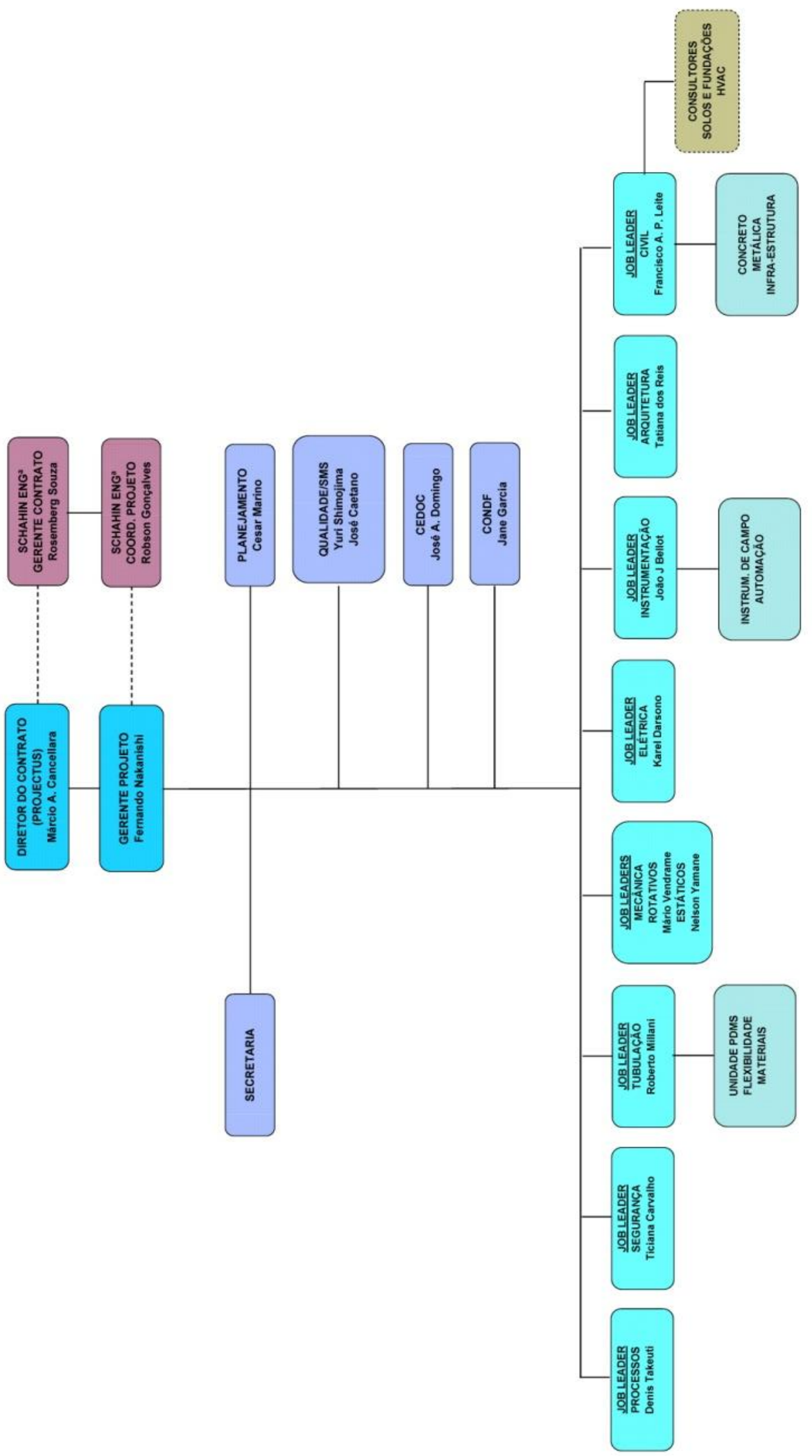

Fonte: Dados de pesquisa 


\subsubsection{Ciclo de vida e processos de projeto}

$\mathrm{Na}$ fase de contratação, o cliente abriu um processo de negociação com a empresa que apresentou menor valor na licitação. Porém, o valor estava acima do orçado pelo cliente e por isso houve uma extensa negociação financeira nesta fase de licitação, que se iniciou em março de 2009. Como resultado, houve a necessidade de reduzir o orçamento para elaboração do projeto de engenharia do empreendimento em 20\%, valor este abaixo dos padrões de remuneração de mercado, à época.

O contrato foi assinado em fevereiro de 2010 e a obra teve início com os serviços de instalação do canteiro de obras. O cliente disponibilizou à contratada as instalações provisórias existentes no local, gerando certa economia inicial, porém estas instalações ocasionaram interferências na sequência de construção e montagem, sendo desativadas e criando dificuldades com realocação do pessoal, pois havia pouco espaço disponível. Além disso, surgiram problemas no planejamento, por quebra do ritmo da obra.

Segundo relato da construtora, durante a fase de execução propriamente dita foram enfrentadas outras dificuldades:

- O empreendimento estava localizado em uma grande área industrial onde havia empreendimentos sendo construídos e outros já concluídos e em operação. Foram encontradas muitas interferências (underground) de instalações não mapeadas, pois o "as built" não refletia algumas instalações subterrâneas, ou seja, estava desatualizado. A contratada possuía em seu escopo o levantamento e estudo de interferências, mas para underground foram utilizados documentos de referência disponibilizados pelo cliente;

- A interligação enterrada (underground) site - subestação, de 400m de comprimento, foi dificultada, pois havia um canteiro de obras de outra construtora causando interferência no seu caminhamento. Estava prevista a desmobilização do canteiro da outra construtora antes do início dessa atividade, porém a desmobilização atrasou, afetando a execução dessa interligação;

- Questões climáticas motivaram aditivos de prazo, pois a grande quantidade de dias chuvosos interferiu no cronograma de execução; 
- Foram identificados problemas com a especificação e quantidades de materiais, devido a falhas em verificações de projeto e equívocos nas unidades dos quantitativos;

- Ocorreram problemas com o alinhamento de decisões e compatibilização entre os muitos stakeholders. O cliente final (representado pelo comitê designado para acompanhar a execução e pessoal da manutenção) muitas vezes não participava das reuniões e sua ausência gerava pontos conflitantes.

\subsubsection{Os agentes do Empreendimento}

Foram identificados como principais agentes do empreendimento:

- Cliente: composto por um conjunto de stakeholders, como equipe de manutenção, produção e diretores;

- Construtora / Gerenciadora: contratada pelo cliente para execução e gestão do empreendimento: execução das atividades de fornecimento de materiais, equipamentos e serviços, relativos a projeto executivo, construção civil e montagem eletromecânica, comissionamento, assistência à pré-operação, partida e operação assistida;

- Projetista: atuação como "terceirizada" em relação ao cliente final. As principais atividades declaradas no escopo contratado são: Gerenciamento, Planejamento e Controle do Projeto / Análise de Consistência do Projeto Básico / Elaboração da Engenharia de Detalhamento / Assistência Técnica;

- Montadora: atuação também como "terceirizada" em relação ao cliente final.

Os organogramas que mostram as relações entre todos os agentes estão representados nas Figuras 41 a 49. 
Figura 41 - Organograma geral - Estudo de Caso 3

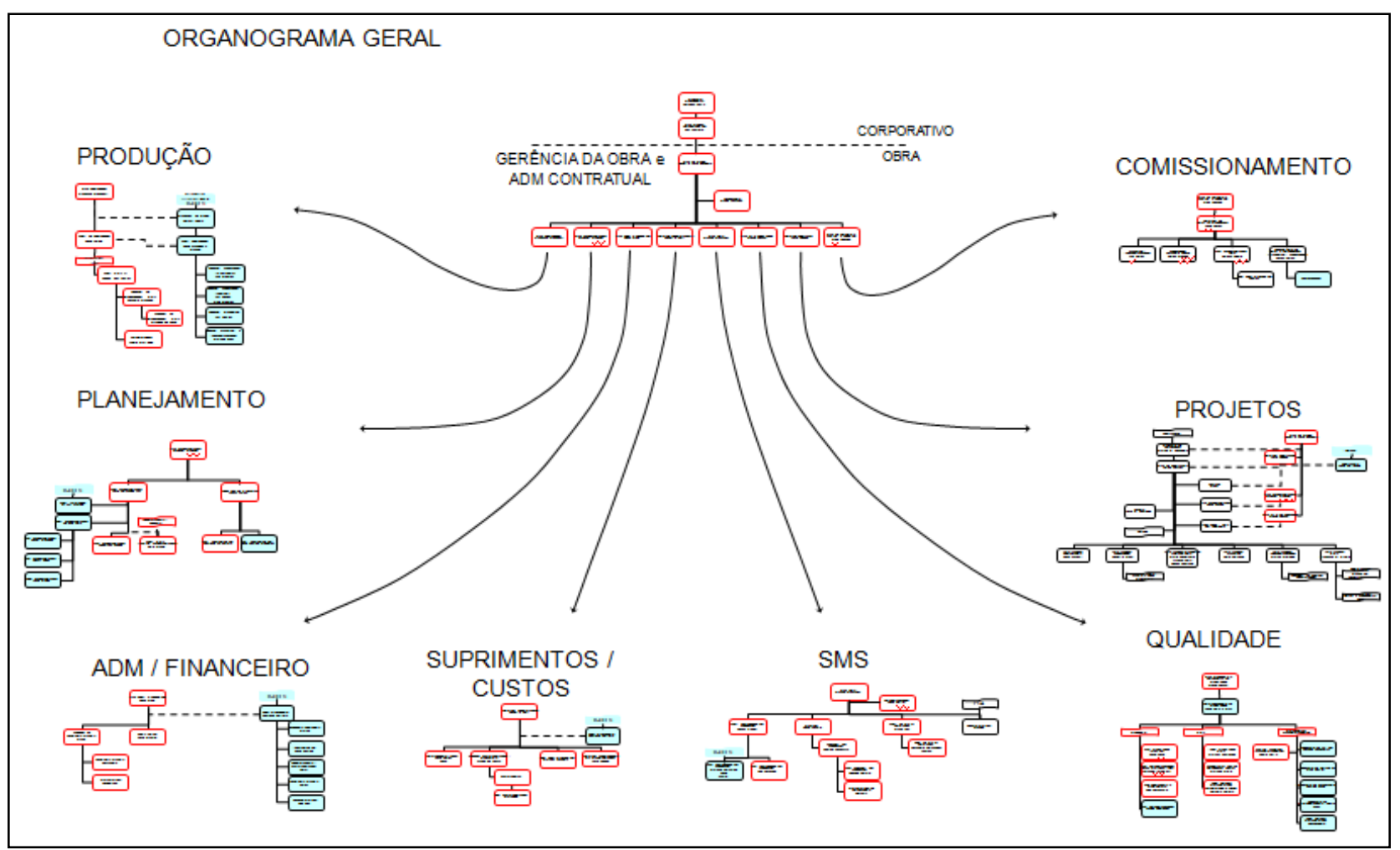

Fonte: Dados de pesquisa 
Figura 42 - Organograma da equipe de produção - Estudo de Caso 3

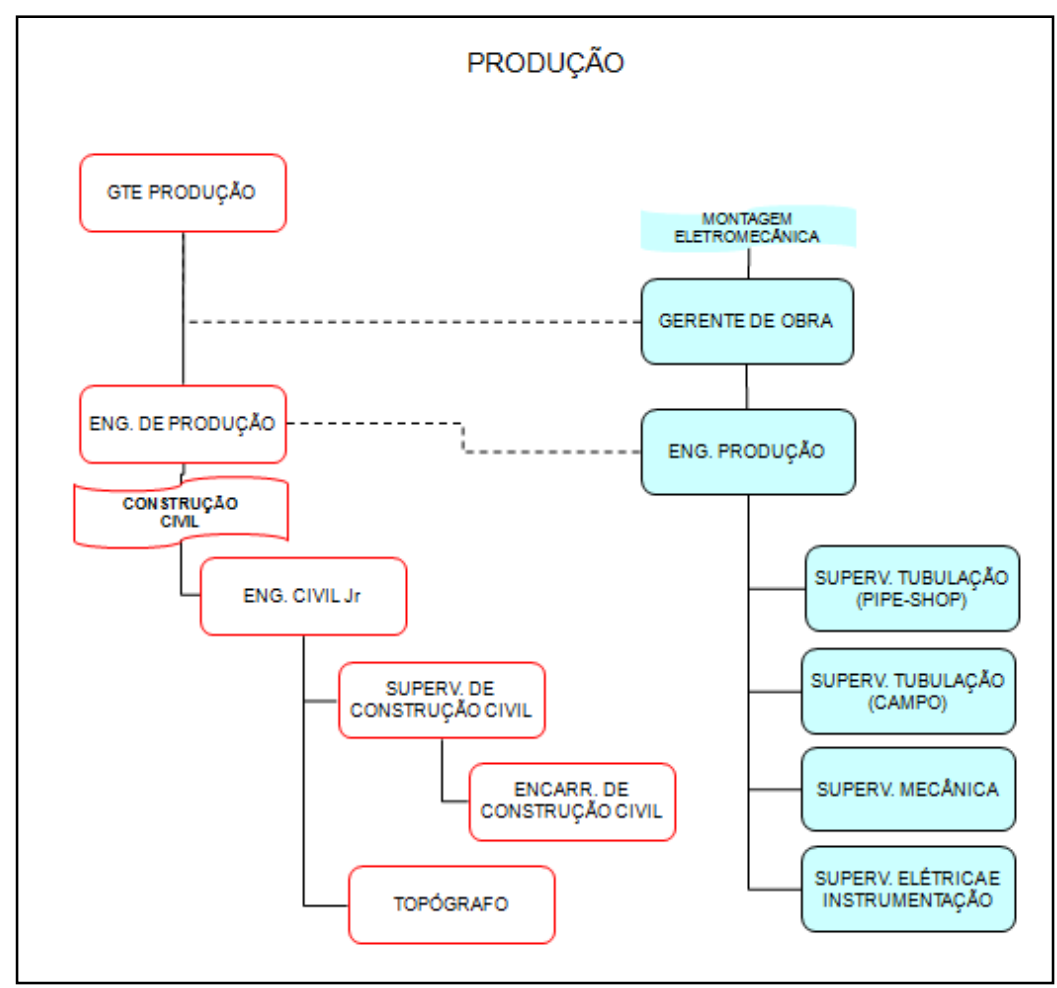

Fonte: Dados de pesquisa

Figura 43 - Organograma da equipe de planejamento - Estudo de Caso 3

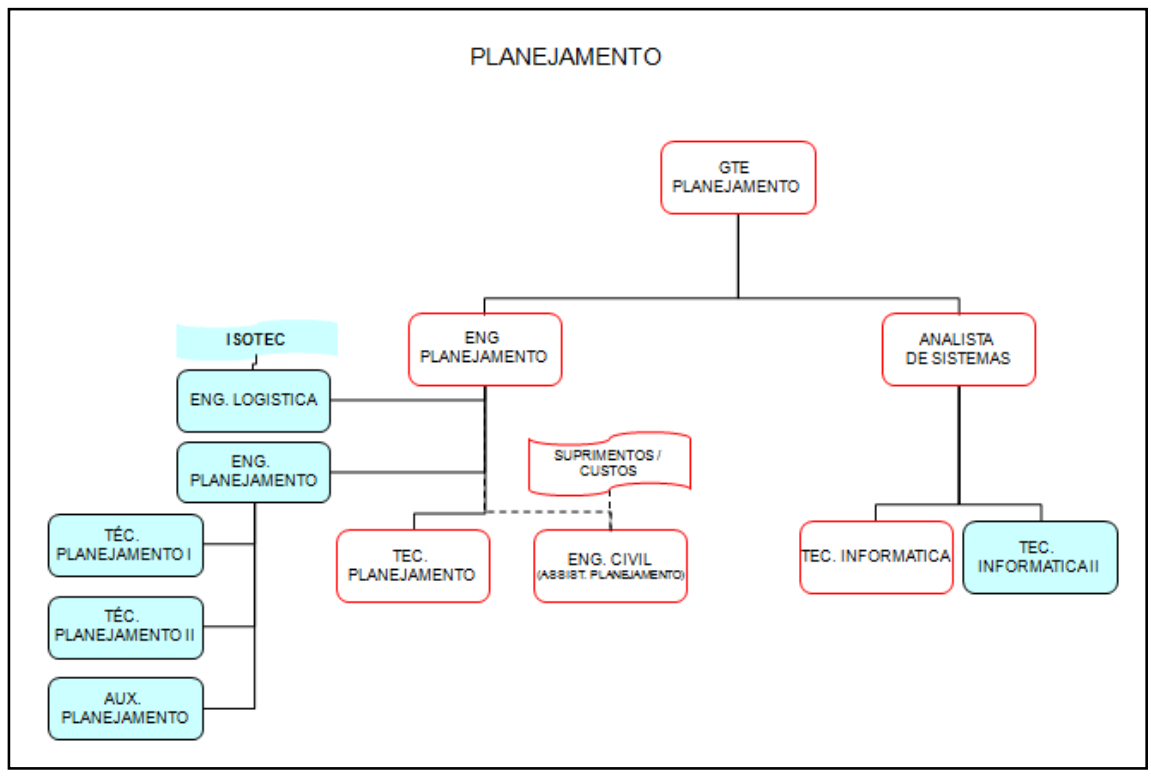

Fonte: Dados de pesquisa 
Figura 44 - Organograma da equipe administrativa e financeiro - Estudo de Caso 3

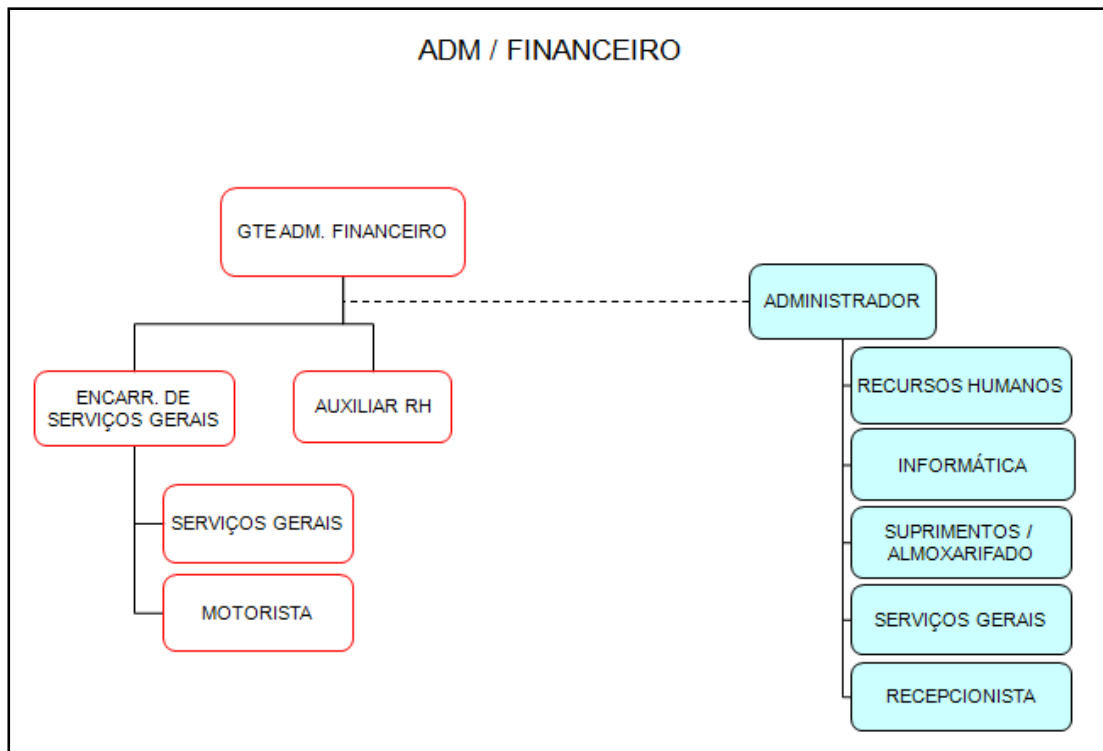

Fonte: Dados de pesquisa

Figura 45 - Organograma da equipe de suprimentos e custos - Estudo de Caso 3

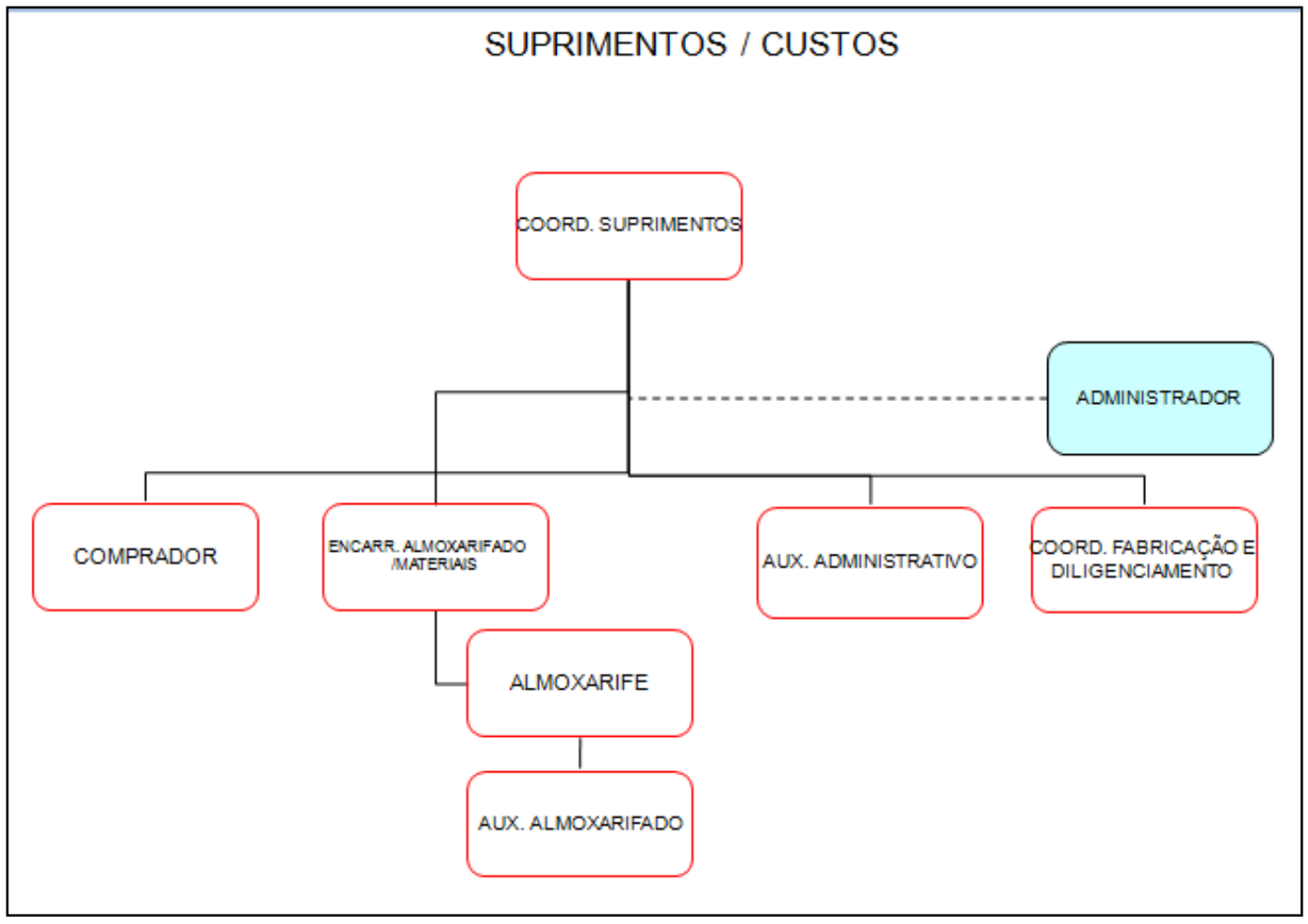

Fonte: Dados de pesquisa 
Figura 46 - Organograma da equipe de segurança, meio ambiente e saúde - Estudo de Caso 3

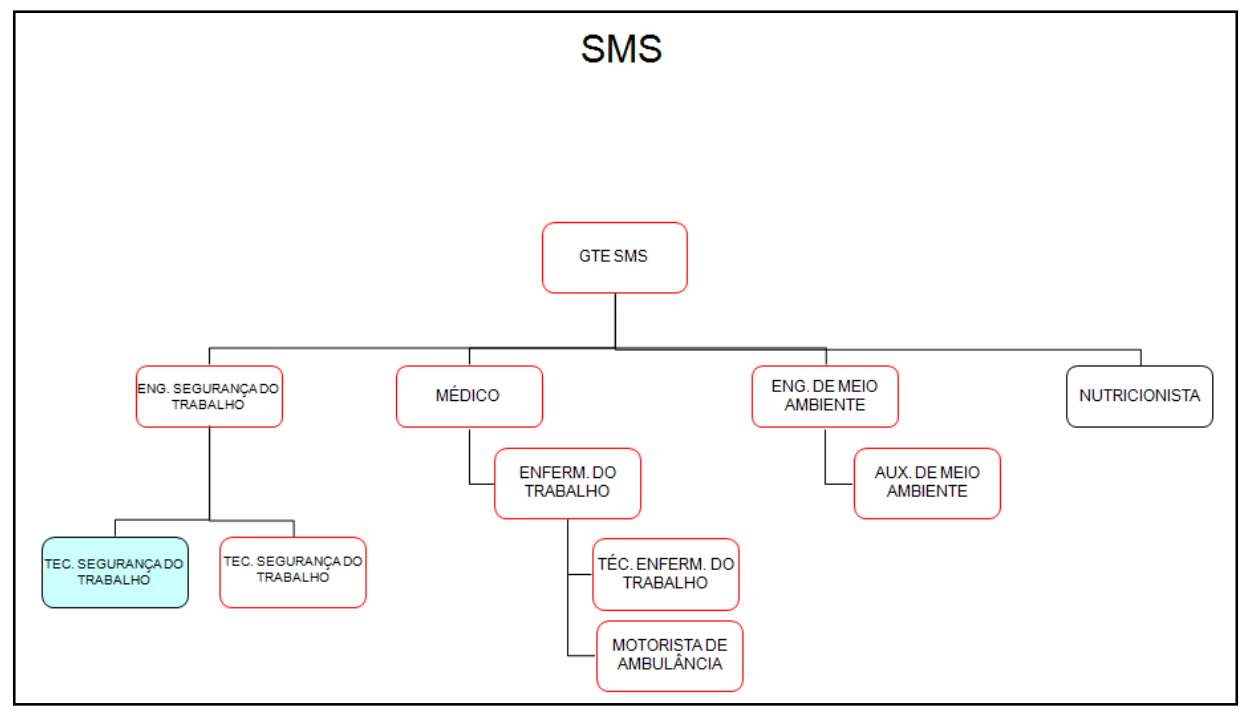

Fonte: Dados de pesquisa

Figura 47 - Organograma da equipe de qualidade - Estudo de Caso 3

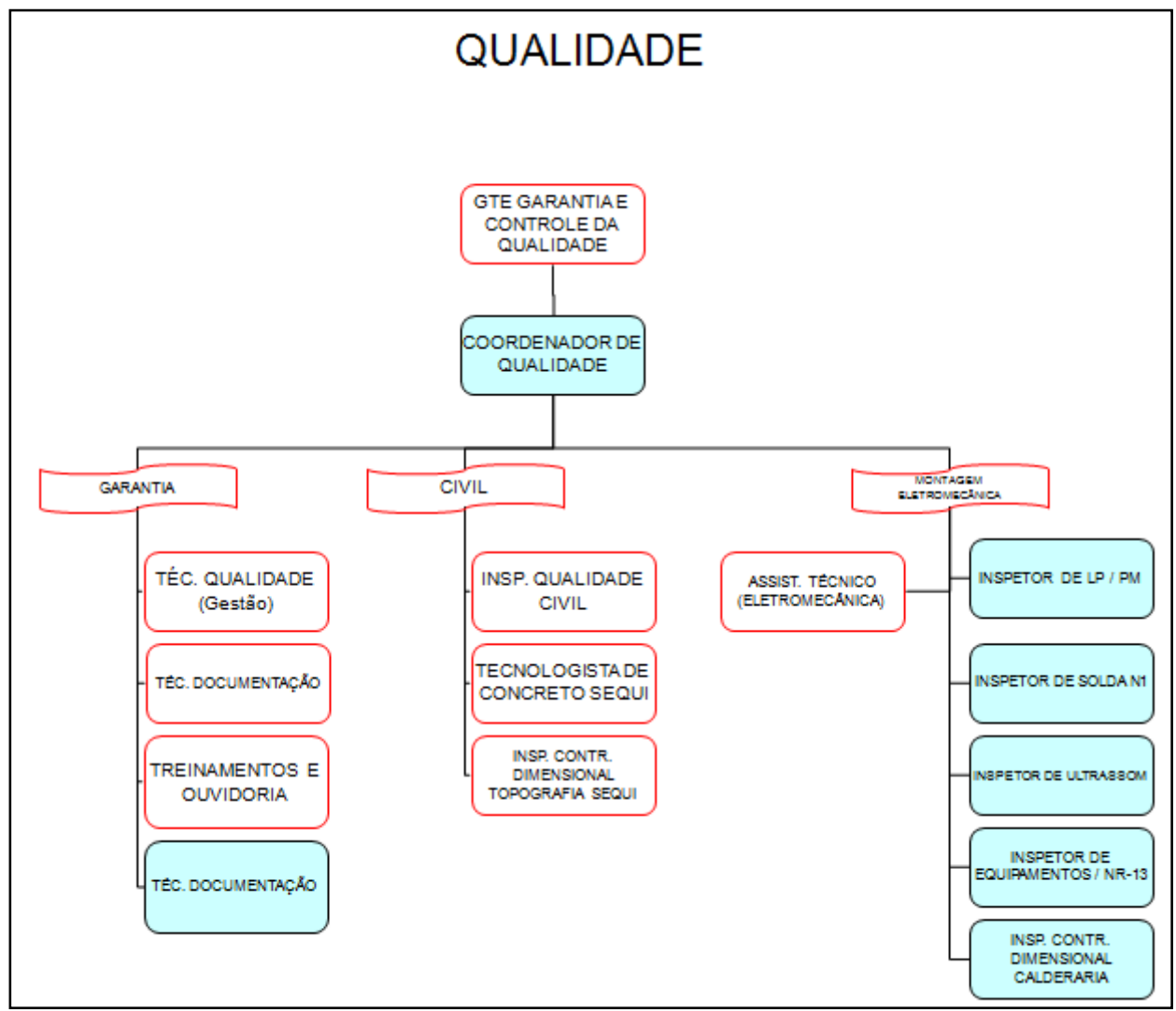

Fonte: Dados de pesquisa 
Figura 48 - Organograma da equipe de projeto - Estudo de Caso 3

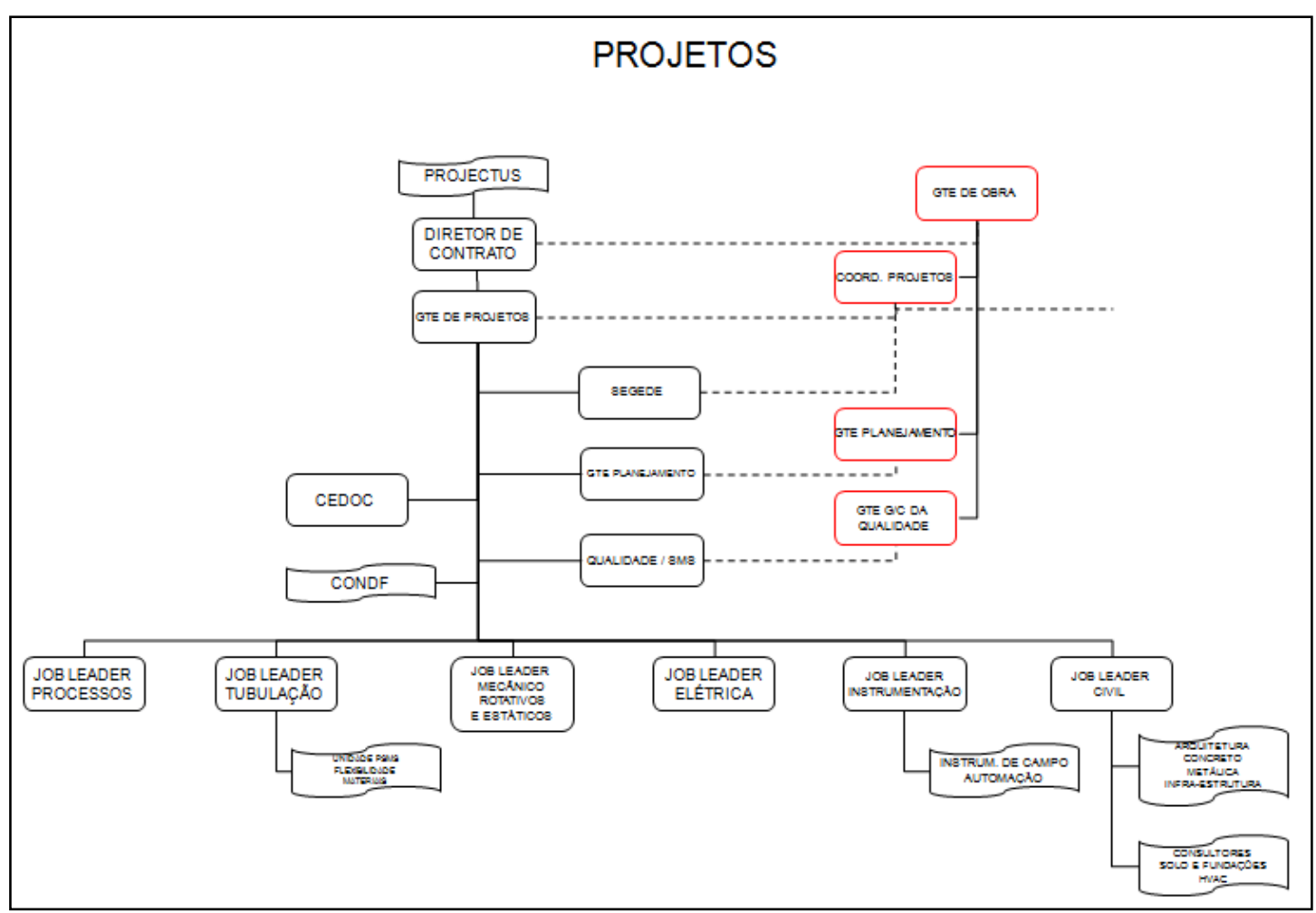

Fonte: Dados de pesquisa

Figura 49 - Organograma da equipe de comissionamento - Estudo de Caso 3

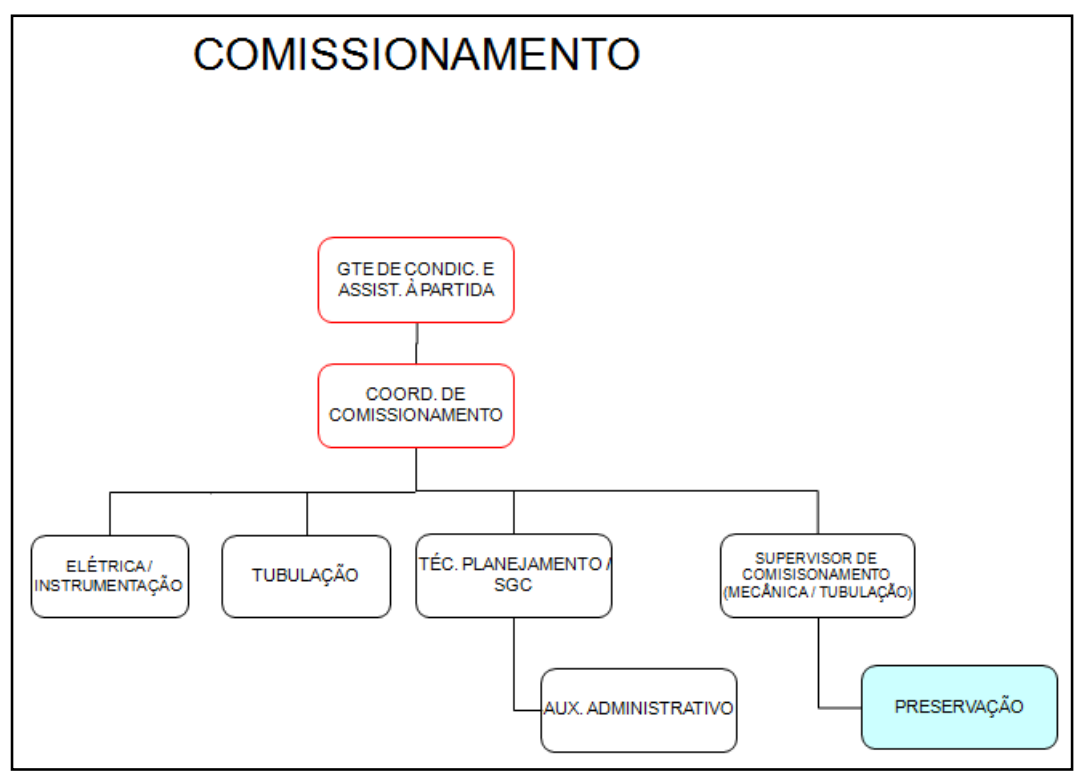

Fonte: Dados de pesquisa 


\subsubsection{Gestão de Riscos}

A construtora, que também atuou como gerenciadora, não realizou análise de risco quanto às atividades que dependiam de fatores externos como, por exemplo, o atraso da desmobilização do canteiro vizinho que afetou a execução do caminhamento da interligação enterrada. Caso esse risco tivesse sido identificado, avaliado, monitorado e controlado, muito provavelmente não ocorreria atraso ou esse seria minimizado. Outro exemplo da falta de gestão de riscos foi a questão climática, pois uma análise dos índices pluviométricos da região poderia ser suficiente para a identificação, avaliação, monitoramento e controle desse risco, minimizando os impactos no prazo que foram gerados.

Também não foi realizada a gestão de riscos pela projetista, por exemplo, no que diz respeito à elaboração do projeto com a obra em andamento. Havia a necessidade de se projetar o mais rápido possível, pois a construtora aguardava informações e qualquer atraso ou ociosidade da equipe da construtora poderia ser repassada à projetista, provocando prejuízos. A identificação, avaliação, monitoramento e controle desse risco poderiam evitar problemas de qualidade no projeto e atender aos prazos exigidos pelo cliente.

\subsubsection{Gestão da Informação e Comunicação (Interface Projeto - Obra)}

A redução de orçamento na etapa de negociação do contrato foi responsável por alguns prejuízos; por exemplo, não havia uma equipe de engenharia multidisciplinar para acompanhamento e verificação do projeto elaborado pela projetista. Foram realizadas reuniões de planejamento e compatibilização (chamadas de walk through review) apenas quando a obra já estava em andamento.

Havia um canal oficial de envio e recebimento de projetos chamado SIGEM. A projetista disponibilizava seus documentos e desenhos por meio desse sistema; a construtora os recebia e enviava ao cliente final.

Apesar de as equipes de gestão e planejamento terem elaborado uma matriz de distribuição de documentos, os responsáveis de distribuição dos projetos não enviavam os documentos para as devidas áreas envolvidas de acordo com essa matriz. Foi relatada também a utilização de 
documentos de revisões superadas pela equipe da obra e a falta de informatização no controle de distribuição dos projetos.

Houve ainda um fator geográfico que gerou conflitos para a interação equipe de obra - equipe de projeto, pois a projetista se localizava na capital e a obra no interior do estado de São Paulo. A comunicação era realizada por meio do coordenador de projetos, porém havia canais abertos entre os projetistas e o pessoal da obra. A projetista não mobilizou equipe para ATO (Assistência Técnica à Obra) devido à redução de orçamento. A mobilização era feita conforme a necessidade e era demorada, o que gerava impactos. Sendo assim, não havia projetistas de prontidão para elaborar croquis / mark up na obra, a construtora acionava a projetista e a demora no envio de recursos gerava mão de obra ociosa e atrasos.

A contratação da projetista foi realizada a um valor não muito atrativo, devido à redução da verba disponibilizada pelo cliente final. Portanto, o orçamento não suportava um grupo tarefa específico, ou seja, uma equipe de projetistas e engenheiros alocados em tempo integral para desenvolvimento do projeto. Além disso, o projeto era considerado de menor relevância para a projetista, o que dificultou a interação equipe de obra - equipe de projeto, originando, por exemplo, dificuldades na comunicação, atrasos e demora na resposta a questionamentos enviados pela equipe de obra, com consequente falta de comprometimento com os prazos.

O projeto foi executado com obra em andamento (ver na Figura 50 as curvas sobrepostas de engenharia, obra civil e montagem) o que gerou impactos na comunicação projeto-obra quanto à programação de atividades de execução em campo. Foi relatado pela construtora que os atrasos e falhas dos projetos geraram prejuízos financeiros e impactos quanto a prazo na construção e montagem. Observando-se as curvas de avanço físico previstas, a elaboração do projeto e a execução em campo mostram-se sobrepostas praticamente ao longo de todo o prazo previsto para entrega final do empreendimento. A curva de avanço físico geral é apresentada na Figura 51. 
Figura 50 - Curva de avanço físico (engenharia, obra civil e montagem) - Estudo de Caso 3

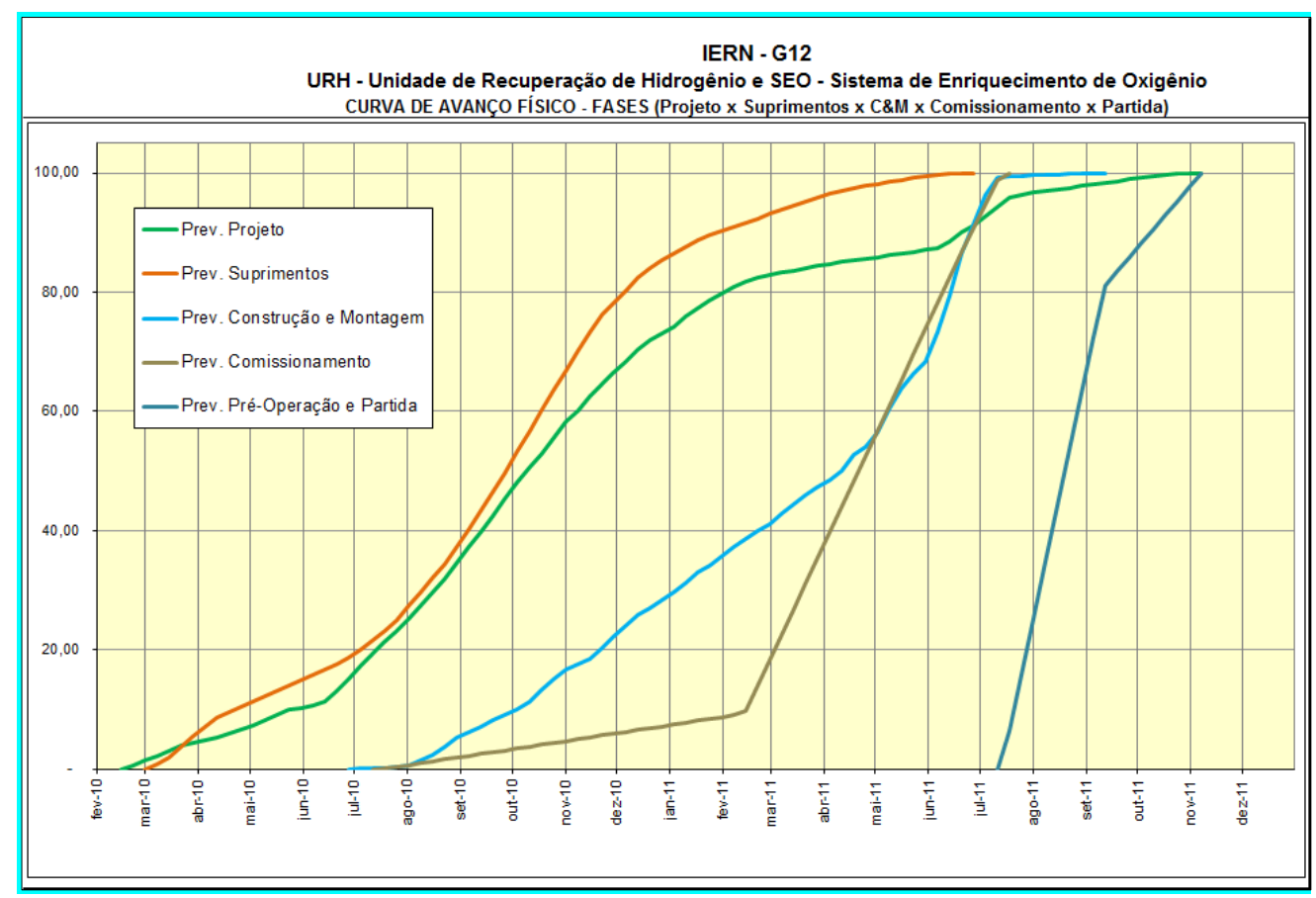

Fonte: Dados de pesquisa

Figura 51 - Curva de avanço físico geral - Estudo de Caso 3

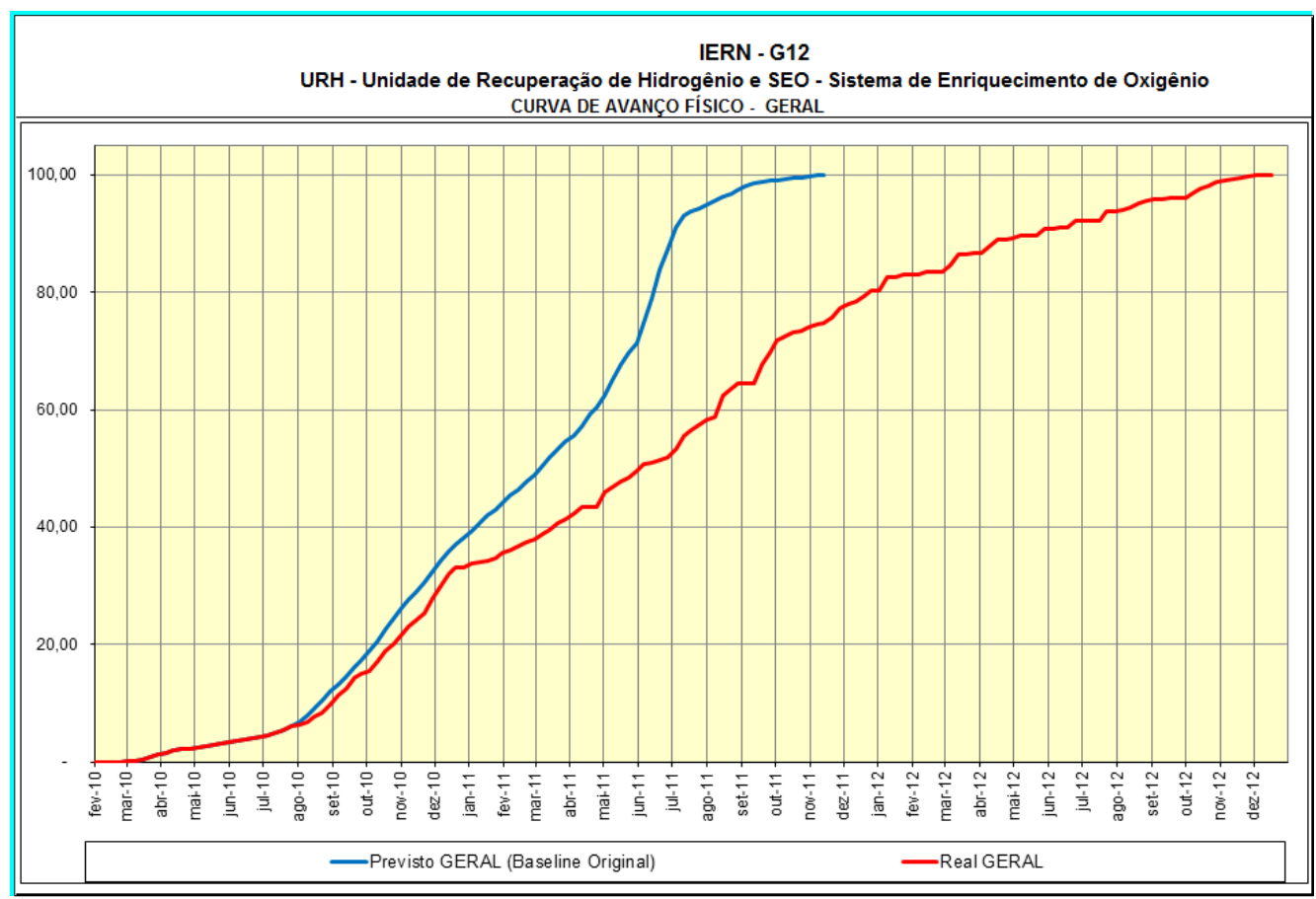

Fonte: Dados de pesquisa 


\subsubsection{Gestão da Qualidade}

A construtora teve alguns prejuízos financeiros decorrentes de alterações de prazo devidas ao atraso na entrega dos projetos. Para a produção, um dos principais problemas encontrados em relação aos projetos foram atrasos e falhas de projeto. Segundo o entrevistado, "a execução do piso industrial ocorreu concomitantemente com a montagem eletromecânica e a execução das obras de underground (ex.: drenagens) também ocorreu simultaneamente com a montagem eletromecânica", provocando atrasos na construção e montagem. O que se pôde perceber é que não houve uma efetiva análise crítica do projeto pela projetista, acarretando em falhas. Um dos motivos que levou a essa deficiência foi a questão de prazo, pois com a obra em andamento o quanto antes os projetos fossem entregues menos ociosidade e prejuízos a construtora teria, sendo que esta repassaria esses prejuízos à projetista.

\subsubsection{Gestão do Conhecimento}

O projeto teve, ao longo de seu desenvolvimento, quatro diferentes colaboradores ocupando o cargo de coordenador de projeto, um índice de rotatividade considerado muito alto. De acordo com o engenheiro de planejamento da construtora, essa rotatividade dos membros da equipe de projeto (coordenadores, job leaders e projetistas), provocada pela carência de profissionais e também pela necessidade de atendimento a outros projetos foi a origem da perda de histórico do projeto, de revisões de projetos já aprovados e de muito retrabalho.

Não foi verificado o uso de ferramentas para a gestão do conhecimento, o que ocasiona falta de controle e de alimentação do banco de dados de conhecimento gerado na organização. Além disso, por conta da alta rotatividade de colaboradores mencionada, foi necessária uma intensa gestão para que não houvesse falha ainda maior na rastreabilidade de informações e consequentemente uma gestão de conhecimento ineficaz.

\subsubsection{Relação com os agentes da produção (execução)}

A construtora participou de toda a execução do empreendimento e tinha sempre como seu objetivo a racionalização dos processos construtivos. Sua equipe analisava os projetos recebidos e, quando possível, sugeria alternativas para redução de custos e racionalização. 
Um exemplo foi o projeto de abrigo para um equipamento (shelter) e painéis de controle. Havia a necessidade de se construir uma edificação pequena com proteção apenas para pessoas quando da realização de manutenção. Porém, a projetista desenvolveu uma edificação com proteção para todo o equipamento, implicando uma área construída excessiva. A construtora analisou o projeto e sugeriu a diminuição da área a ser construída, levando a uma redução do custo para um décimo do inicial, além de otimização de espaço físico.

As Figuras 52 e 53 exibem, respectivamente, o projeto e fotos do abrigo dos painéis.

Figura 52 - Abrigo dos painéis - Estudo de Caso 3

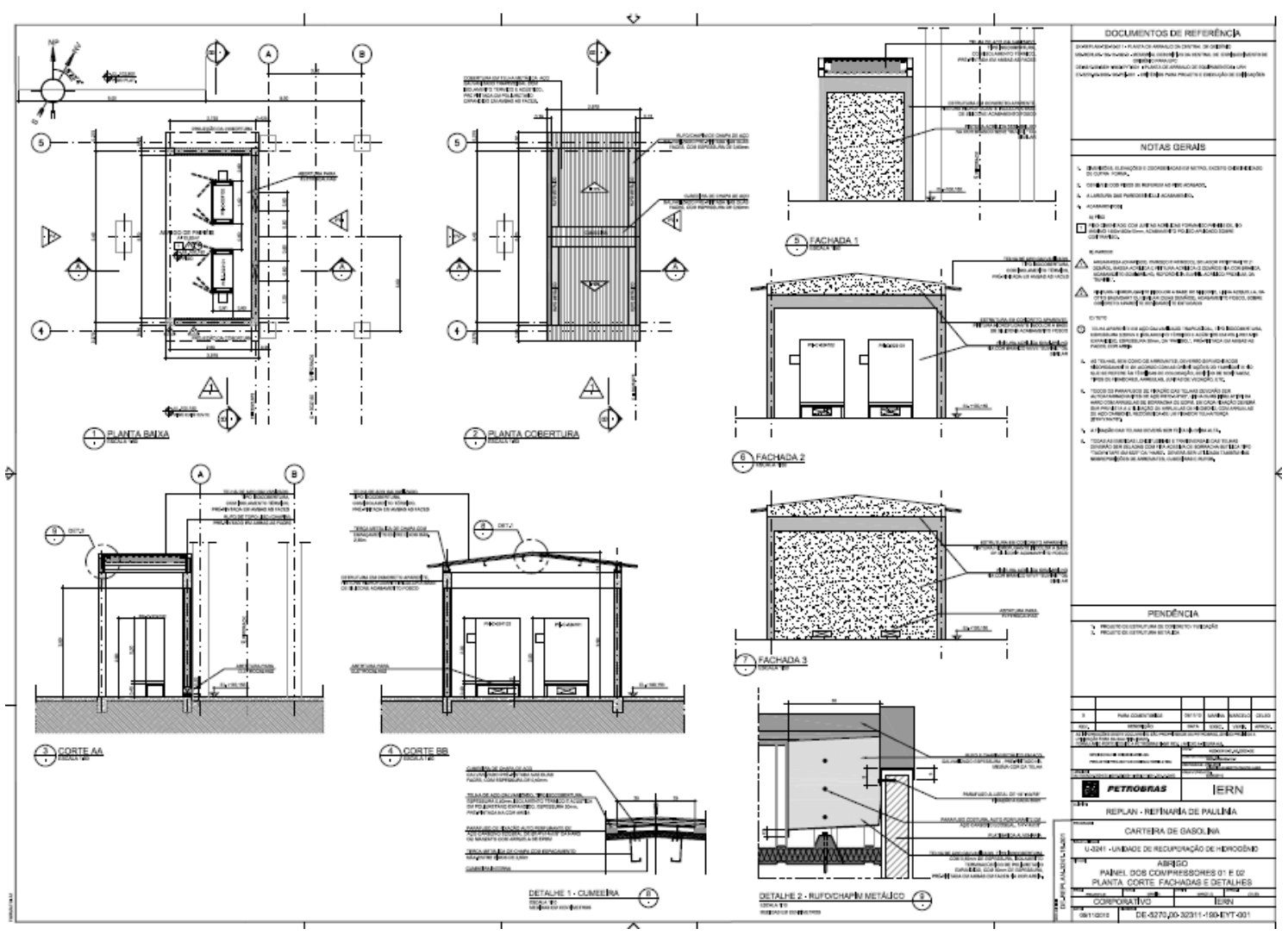

Fonte: Dados de pesquisa 
Figura 53 - Abrigo dos painéis - Estudo de Caso 3
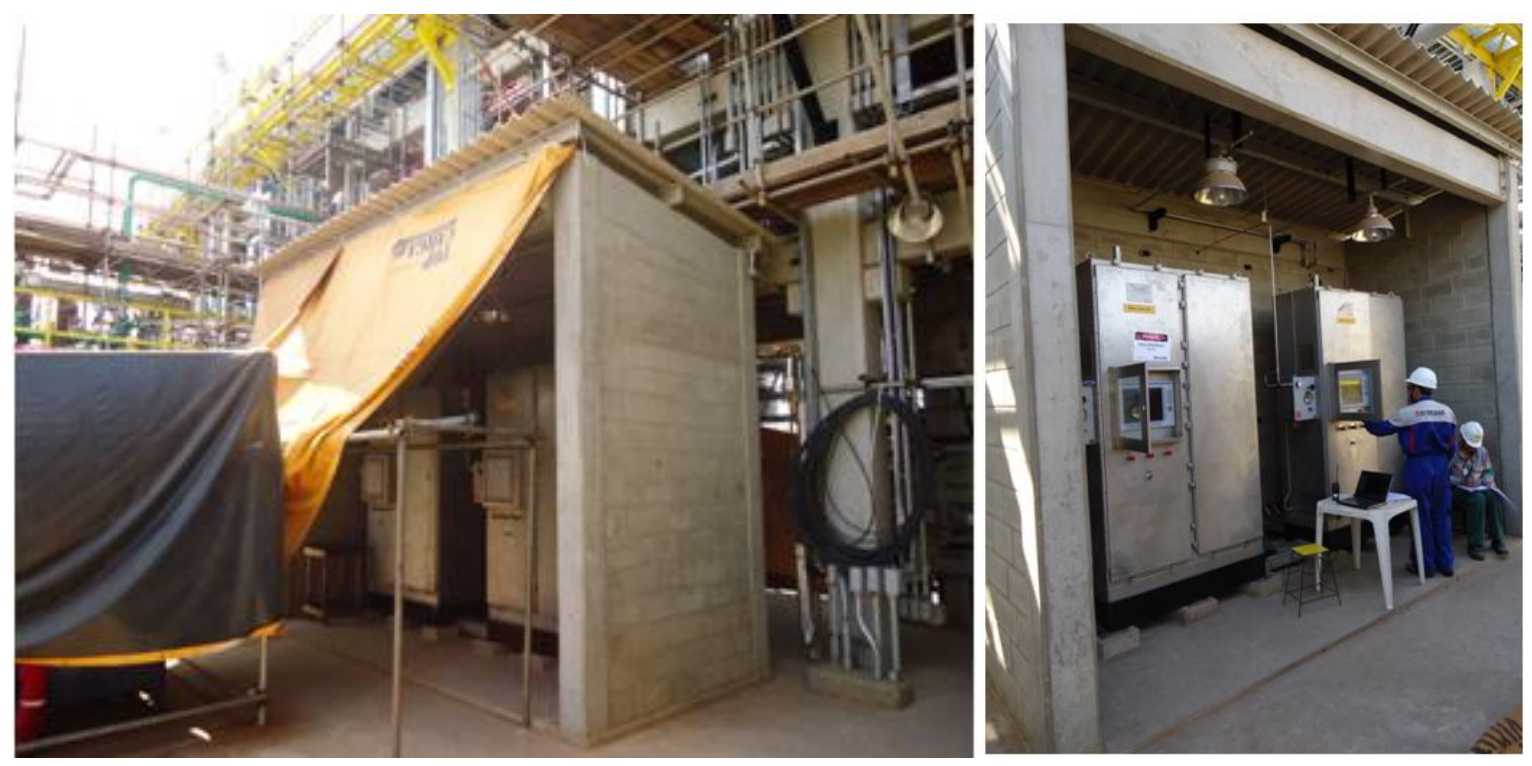

Fonte: Dados de pesquisa

Outra situação mencionada na entrevista envolvia as estacas de fundação, em que o projeto previa vários diâmetros diferentes. A empresa contratada de cravação necessitaria trocar as brocas constantemente (estaca hélice contínua) por conta das variações dos diâmetros. Foi realizado um estudo e decidido adotar um diâmetro único (maior diâmetro apresentado no projeto), que em si mesmo representaria maior custo, porém traria ganho de produtividade e redução do prazo de execução. A preocupação de redução de prazos se justificava pela meta de finalizar os serviços até o final de 2010, antes do inicio dos grandes períodos de chuva.

Também foi relatado que foram propostas otimizações no caminho de alimentação elétrica, de instrumentação e de tubulação. A construtora apresentou alternativas de trajeto visando à redução de material, com consequente diminuição de custos.

\subsection{ANÁLISES E COMPARAÇÕES ENTRE OS ESTUDOS DE CASO}

Na Tabela 2 é apresentado um resumo das principais características dos estudos de caso. É possível observar que, independente do serviço contratado, do porte do projeto ou mesmo empresa contratada, os três projetos estudados apresentaram prazo real de término maior que 
o prazo contratual. Por meio dos dados coletados, pode-se afirmar que esse fato se deveu, dentre outros fatores, às alterações de projeto (mudança de escopo) durante seu desenvolvimento, à inexperiência com softwares, responsável por extensos retrabalhos, e à atuação ineficaz do coordenador de projetos. O papel do coordenador de projetos foi falho, pela falta de análise de riscos, gerando imprevistos com consequências negativas, ou mesmo pela falta de análise, compatibilização e verificação de projetos.

Tabela 2 - Caracterização dos Estudos de Caso

\begin{tabular}{|c|c|c|c|c|c|c|}
\hline \multicolumn{7}{|c|}{ Caracterização dos Estudos de Caso } \\
\hline Empresa & Estudo de Caso & Valor (R\$̣) & Quantidade de HH & Prazo Previsto & Prazo Real & Serviço Contratado \\
\hline A & 1 & $754.594,86$ & 6.000 & 5 meses & 8 meses & Engenharia Detalhada \\
\hline A & 2 & $3.598 .182,78$ & 27.000 & 5 meses & 17 meses & Engenharia Básica e Detalhada \\
\hline B & 3 & $3.682 .712,80$ & 28.000 & 21 meses & 34 meses & $\begin{array}{c}\text { Engenharia Básica / Detalhada e Assistência } \\
\text { Técnica à Construção / Montagem }\end{array}$ \\
\hline
\end{tabular}

Obs.: No estudo de caso 3 é informada a quantidade de $\mathrm{HH}$ e valor para a fase projeto, porém os prazos previsto e real são referentes à soma dos prazos do projeto e da execução da obra.

Fonte: Dados de pesquisa

Após coleta de dados baseada em um protocolo de estudo de caso múltiplo, confrontados com a bibliografia, foram estabelecidos temas prioritários de análise, subdivididos em subtemas (conforme se pode ver nas duas primeiras colunas do Quadro 4).

O Quadro 5 apresenta, de forma resumida, uma síntese contendo as principais observações realizadas nos três estudos de caso. 
Quadro 5 - Síntese dos Estudos de Caso

\begin{tabular}{|c|c|c|c|c|}
\hline Tema & Subtema & Caso 1 (Empresa A) & Caso 2 (Empresa A) & Caso 3 (Empresa B) \\
\hline \multirow[t]{2}{*}{$\begin{array}{l}\text { Gestão de } \\
\text { Projetos }\end{array}$} & $\begin{array}{l}\text { Project } \\
\text { Mana- } \\
\text { gement }\end{array}$ & $\begin{array}{l}\text { Iniciação: informação } \\
\text { de referência (falta de } \\
\text { informações reais e } \\
\text { confiáveis dos principais } \\
\text { equipamentos do } \\
\text { empreendimento / } \\
\text { sondagem realizada em } \\
\text { período de seca) } \\
\text { Planejamento: } \\
\text { contratação de terceiros } \\
\text { Execução: integração } \\
\text { entre atividades, riscos } \\
\text { Controle: terceiros } \\
\text { Encerramento: n.a. }\end{array}$ & $\begin{array}{l}\text { Iniciação: informação } \\
\text { de referência (falta de } \\
\text { informações reais e } \\
\text { confiáveis dos principais } \\
\text { equipamentos - } \\
\text { utilizados catálogos / } \\
\text { layout da área de } \\
\text { microbiologia divergia } \\
\text { de informações enviadas } \\
\text { no início do projeto / } \\
\text { atraso na definição de } \\
\text { reatores / Problemas na } \\
\text { fase de execução - “as } \\
\text { built” - interferências de } \\
\text { tubulações) } \\
\text { Falta de experiência da } \\
\text { projetista em BIM } \\
\text { Planejamento: } \\
\text { esclarecimento do nível } \\
\text { de detalhamento do } \\
\text { projeto / rotatividade da } \\
\text { equipe da projetista / } \\
\text { inexperiência em BIM e } \\
\text { sistema hidrossanitário a } \\
\text { vácuo (contratação de } \\
\text { terceiros) } \\
\text { Execução: falta de } \\
\text { conhecimento de BIM } \\
\text { Controle: Atividades de } \\
\text { modelagem 3D (a } \\
\text { inexperiência dificultou } \\
\text { controle de atividades / } \\
\text { Muitas alterações de } \\
\text { escopo - dificuldade na } \\
\text { gestão de pessoal } \\
\text { Encerramento: n.a. }\end{array}$ & $\begin{array}{l}\text { Iniciação: informação } \\
\text { de referência ("as built" } \\
\text { desatualizado - } \\
\text { instalações não } \\
\text { mapeadas / } \\
\text { especificações e } \\
\text { quantidades de materiais } \\
\text { falhas) } \\
\text { Planejamento: } \\
\text { mudança de escopo / } \\
\text { questões climáticas / } \\
\text { reestruturação } \\
\text { organizacional da } \\
\text { projetista } \\
\text { Execução: integração de } \\
\text { equipe projeto-obra } \\
\text { (fator geográfico } \\
\text { dificultou o processo de } \\
\text { comunicação) } \\
\text { Controle: Gestão de } \\
\text { MO (falta de controle } \\
\text { das modificações } \\
\text { realizadas - falta de } \\
\text { registro das premissas } \\
\text { adotadas) } \\
\text { Encerramento: n.a. }\end{array}$ \\
\hline & $\begin{array}{l}\text { Design } \\
\text { Mana- } \\
\text { gement }\end{array}$ & $\begin{array}{l}\text { Análise crítica e } \\
\text { verificação do projeto } \\
\text { (design) }\end{array}$ & $\begin{array}{l}\text { Falta de know how } \\
\text { (BIM e sistema } \\
\text { hidrossanitário) }\end{array}$ & $\begin{array}{l}\text { Análise crítica e } \\
\text { verificação do projeto } \\
\text { (design) }\end{array}$ \\
\hline
\end{tabular}


Quadro 5 - Síntese dos Estudos de Caso - Continuação

\begin{tabular}{|c|c|c|c|c|}
\hline Tema & Subtema & Caso 1 (Empresa A) & Caso 2 (Empresa A) & Caso 3 (Empresa B) \\
\hline \multirow{3}{*}{$\begin{array}{c}\text { Gestão do } \\
\text { Processo } \\
\text { de Projeto }\end{array}$} & $\begin{array}{c}\text { Etapas } \\
\text { do } \\
\text { Processo } \\
\text { de } \\
\text { Projeto }\end{array}$ & $\begin{array}{l}\text { Falta de informações } \\
\text { necessárias para } \\
\text { desenvolvimento das } \\
\text { atividades - utilizado } \\
\text { referências disponíveis } \\
\text { em etapas anteriores } \\
\text { (projeto básico) } \\
\text { Falta de recursos } \\
\text { disponíveis para } \\
\text { realização do projeto de } \\
\text { drenagem - contratação } \\
\text { de terceiros } \\
\text { Falta de gestão da } \\
\text { contratação de terceiros }\end{array}$ & $\begin{array}{l}\text { Atraso na definição de } \\
\text { requisitos (dados de } \\
\text { processo, especificações } \\
\text { de tanques) } \\
\text { Falta de informações de } \\
\text { referência necessárias } \\
\text { para desenvolvimento } \\
\text { das atividades - utilizado } \\
\text { referências disponíveis } \\
\text { em catálogos de } \\
\text { equipamentos } \\
\text { Grande quantidade e } \\
\text { nível de alterações de } \\
\text { projeto solicitado pelo } \\
\text { cliente. }\end{array}$ & 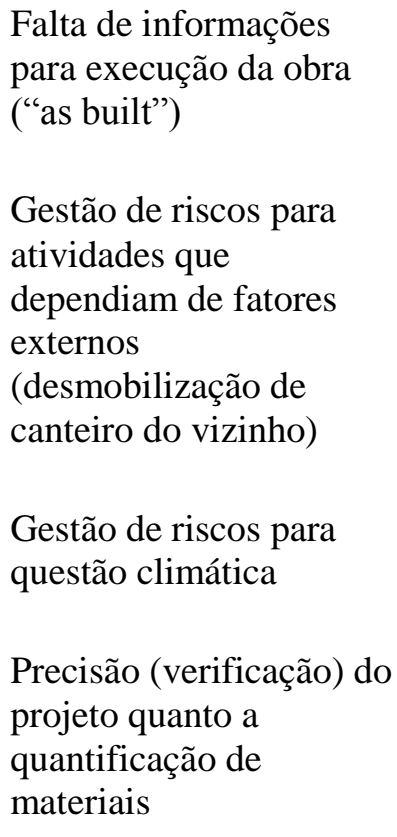 \\
\hline & $\begin{array}{l}\text { Agentes } \\
\text { Envol- } \\
\text { vidos }\end{array}$ & $\begin{array}{l}\text { Cliente } \\
\text { Consultoria técnica } \\
\text { externa } \\
\text { Projetista }\end{array}$ & $\begin{array}{l}\text { Cliente } \\
\text { Gerenciadora } \\
\text { Construtora / Montadora } \\
\text { Projetista }\end{array}$ & $\begin{array}{l}\text { Cliente } \\
\text { Construtora/ } \\
\text { Gerenciadora } \\
\text { Projetista } \\
\text { Montadora }\end{array}$ \\
\hline & $\begin{array}{c}\text { Equipe } \\
\text { Multidis- } \\
\text { ciplinar e } \\
\text { Coorde- } \\
\text { nação }\end{array}$ & $\begin{array}{l}\text { Rotatividade de } \\
\text { coordenadores e } \\
\text { planejadores }\end{array}$ & $\begin{array}{l}\text { Muitas alterações na } \\
\text { liderança, tanto no corpo } \\
\text { técnico como na gestão } \\
\text { por parte da projetista }\end{array}$ & $\begin{array}{l}\text { Rotatividade dos } \\
\text { membros da equipe de } \\
\text { projeto (coordenadores, } \\
\text { job leaders e projetistas) } \\
\text { devido à carência de } \\
\text { profissionais e também } \\
\text { ao atendimento a outros } \\
\text { projetos gerou perda de } \\
\text { histórico do projeto, } \\
\text { revisões de projetos já } \\
\text { aprovados e muito } \\
\text { retrabalho }\end{array}$ \\
\hline $\begin{array}{l}\text { Contrata- } \\
\text { ção de } \\
\text { Projetos }\end{array}$ & $\begin{array}{l}\text { Modali- } \\
\text { dade }\end{array}$ & Preço Global & Preço Global & Preço Global \\
\hline
\end{tabular}


Quadro 5 - Síntese dos Estudos de Caso - Continuação

\begin{tabular}{|c|c|c|c|c|}
\hline Tema & Subtema & Caso 1 (Empresa A) & Caso 2 (Empresa A) & Caso 3 (Empresa B) \\
\hline $\begin{array}{c}\text { Estrutura } \\
\text { Organiza- } \\
\text { cional }\end{array}$ & Tipologia & Matricial & Matricial & Matricial \\
\hline $\begin{array}{l}\text { Gestão de } \\
\text { Riscos }\end{array}$ & & $\begin{array}{l}\text { Não foi elaborada } \\
\text { nenhuma análise de } \\
\text { risco quanto à aquisição } \\
\text { de serviços externos. }\end{array}$ & $\begin{array}{l}\text { Não foi realizada análise } \\
\text { de risco quanto à falta } \\
\text { de conhecimento e } \\
\text { primeira experiência na } \\
\text { elaboração de projeto } \\
\text { utilizando o sistema } \\
\text { BIM. }\end{array}$ & $\begin{array}{l}\text { A construtora / } \\
\text { gerenciadora não } \\
\text { realizou análise de risco } \\
\text { quanto atividades que } \\
\text { dependiam de fatores } \\
\text { externos, como por } \\
\text { exemplo, o atraso da } \\
\text { desmobilização do } \\
\text { canteiro vizinho que } \\
\text { afetou a execução do } \\
\text { caminhamento da } \\
\text { interligação enterrada. } \\
\text { Também não foi } \\
\text { realizada a gestão de } \\
\text { riscos pela projetista, } \\
\text { por exemplo, no que diz } \\
\text { respeito à elaboração do } \\
\text { projeto com a obra em } \\
\text { andamento } \\
\text { Outro exemplo da falta } \\
\text { de gestão de riscos foi } \\
\text { em relação à questão } \\
\text { climática. }\end{array}$ \\
\hline $\begin{array}{l}\text { Gestão da } \\
\text { Infor- } \\
\text { mação e } \\
\text { da } \\
\text { Comuni- } \\
\text { cação }\end{array}$ & $\begin{array}{l}\text { Gestão } \\
\text { da Infor- } \\
\text { mação }\end{array}$ & $\begin{array}{l}\text { Informações de } \\
\text { referência faltantes } \\
\text { Informações de projeto } \\
\text { recebidas de terceiros } \\
\text { não verificadas, ou seja, } \\
\text { não confiáveis }\end{array}$ & $\begin{array}{l}\text { Informações de } \\
\text { referência faltantes }\end{array}$ & $\begin{array}{l}\text { Atraso na entrega do } \\
\text { projeto (recursos } \\
\text { insuficientes para a } \\
\text { necessidade do projeto) } \\
\text { gerando problemas a } \\
\text { resolver na fase de } \\
\text { execução } \\
\text { Falta de informação pelo } \\
\text { cliente para "as built" }\end{array}$ \\
\hline
\end{tabular}


Quadro 5 - Síntese dos Estudos de Caso - Continuação

\begin{tabular}{|c|c|c|c|c|}
\hline Tema & Subtema & Caso 1 (Empresa A) & Caso 2 (Empresa A) & Caso 3 (Empresa B) \\
\hline $\begin{array}{l}\text { Gestão da } \\
\text { Infor- } \\
\text { mação e } \\
\text { da } \\
\text { Comuni- } \\
\text { cação }\end{array}$ & $\begin{array}{c}\text { Gestão } \\
\text { da } \\
\text { Comu- } \\
\text { nicação }\end{array}$ & $\begin{array}{l}\text { Falta de plano de } \\
\text { comunicação com } \\
\text { terceiro }\end{array}$ & $\begin{array}{l}\text { As várias formas de } \\
\text { recebimento de projetos } \\
\text { (solicitadas pelo próprio } \\
\text { cliente) geraram } \\
\text { utilização de revisões } \\
\text { superadas na obra } \\
\text { O cliente também não } \\
\text { tinha controle interno de } \\
\text { recebimento de projetos } \\
\text { efetivo } \\
\text { Falta de recursos por } \\
\text { parte do cliente para } \\
\text { atender a demanda de } \\
\text { definições de projeto } \\
\text { (equipe reduzida sem } \\
\text { todas as especialidades } \\
\text { necessárias) }\end{array}$ & $\begin{array}{l}\text { Não cumprimento da } \\
\text { matriz de distribuição de } \\
\text { documentos (falta de } \\
\text { controle de versões dos } \\
\text { projetos / utilização de } \\
\text { revisões superadas na } \\
\text { obra) } \\
\text { Fator geográfico equipe } \\
\text { projeto - equipe obra } \\
\text { Falta de equipe de } \\
\text { engenharia } \\
\text { multidisciplinar para } \\
\text { verificação e análise } \\
\text { crítica do projeto } \\
\text { A projetista não } \\
\text { mobilizou equipe para } \\
\text { assistência técnica a } \\
\text { obra devido à redução } \\
\text { de orçamento, ou seja, } \\
\text { não foram alocados } \\
\text { recursos para essa } \\
\text { atividade }\end{array}$ \\
\hline $\begin{array}{l}\text { Gestão da } \\
\text { Qualidade }\end{array}$ & & $\begin{array}{l}\begin{array}{l}\text { Falta de qualidade nas } \\
\text { informações de } \\
\text { referência recebidas pelo } \\
\text { cliente }\end{array} \\
\begin{array}{l}\text { Falta de verificação e } \\
\text { análise crítica dos } \\
\text { projetos quanto às } \\
\text { contratações externas }\end{array}\end{array}$ & $\begin{array}{l}\text { Informação de } \\
\text { referência pelo cliente } \\
\text { (no "as built" não havia } \\
\text { locação de dutos, o que } \\
\text { causou incidente em } \\
\text { obra quando da } \\
\text { perfuração de estacas) }\end{array}$ & $\begin{array}{l}\text { Validação de projeto } \\
\text { pelo cliente quanto à } \\
\text { análise, comentário e } \\
\text { aprovação (não havia } \\
\text { recurso) } \\
\text { Utilização de revisões } \\
\text { superadas de projeto na } \\
\text { obra } \\
\text { Informação de } \\
\text { referência pelo cliente } \\
\text { ("as built") }\end{array}$ \\
\hline
\end{tabular}


Quadro 5 - Síntese dos Estudos de Caso - Final

\begin{tabular}{|c|l|l|l|l|}
\hline Tema & Subtema & \multicolumn{1}{|c|}{ Caso 1 (Empresa A) } & Caso 2 (Empresa A) & \multicolumn{1}{c|}{ Caso 3 (Empresa B) } \\
\hline $\begin{array}{c}\text { Gestão do } \\
\begin{array}{c}\text { Conhe- } \\
\text { cimento }\end{array}\end{array}$ & $\begin{array}{l}\text { Falta de controle e } \\
\text { banco de dados de } \\
\text { conhecimento: lição } \\
\text { aprendida quanto à } \\
\text { contratação de terceiros }\end{array}$ & $\begin{array}{l}\text { Falta de controle e } \\
\text { banco de dados de } \\
\text { conhecimento: lição } \\
\text { aprendida quanto ao uso } \\
\text { de BIM }\end{array}$ & $\begin{array}{l}\text { Organização das } \\
\text { informações (banco de } \\
\text { dados do projeto) }\end{array}$ \\
\hline
\end{tabular}

Fonte: Dados de pesquisa

Como resultado da análise dos casos, e diante dos conceitos de gestão apontados pela revisão bibliográfica, foram detectados pontos em comum que sugerem algumas diretrizes preliminares.

Os dados iniciais para o desenvolvimento do projeto (coleta e entrada de informações) têm grande relevância e estas informações devem ser confiáveis, para que o projeto tenha qualidade, diminuindo riscos em relação a atrasos e aumento de custos.

No Caso 1, foi possível observar que as informações que alimentaram o processo de projeto possuíam um grau de incerteza muito grande e, com a falta de colaboração do cliente no que diz respeito à qualidade da informação, tornaram-se uma grande fonte de prejuízos. No Caso 2, faltaram informações de referência. Nesse mesmo caso, foi bastante crítico o desconhecimento e inexperiência da Empresa Projetista para o uso da Modelagem da Informação da Construção (BIM). Também foi constatada deficiência por alocação insuficiente de recursos (Caso 2).

Em entregas parciais dos projetos, a integração entre as disciplinas envolvidas, compatibilização e análise crítica devem ser considerados "pilares" do processo de projeto. Foram observadas deficiências graves de gestão nesse aspecto, nos casos estudados.

Outro aspecto crítico diz respeito à gestão da qualidade. Nos Casos 2 e 3, problemas gerados pela falta de controle na distribuição de documentos levaram à utilização de versões canceladas pela equipe de obra. 
Dada a análise dos casos estudados, podem ser elencadas sete diretrizes para a gestão de projetos, dentro do contexto característico dos três casos:

Diretriz 1: prioridade deve ser dada à definição e correta aplicação da matriz de responsabilidades do projeto, incluindo-se o cliente e suas equipes técnicas, como forma de prevenir decisões erradas, mal fundamentadas ou não validadas.

Diretriz 2: atenção quanto à qualidade da informação disponibilizada pelo cliente ou por terceiros, submetendo-a a verificação e análise crítica, em todas as etapas, de modo a tornar o projeto confiável e reduzir retrabalho.

Diretriz 3: um sistema de controle de documentação, confiável e capaz de rastrear a circulação dos documentos de projeto, é imprescindível para se garantir que as informações corretas prevaleçam.

Diretriz 4: a qualificação e dimensionamento das equipes de projeto deve ter garantia de adequação aos requisitos de projeto estabelecidos desde o contrato; eventuais situações de qualificação insuficiente devem ser objeto de capacitação e treinamentos prévios.

Diretriz 5: identificada a necessidade de aquisição de serviços externos, deve-se elaborar uma análise de riscos, principalmente em relação a prazo e qualidade, de modo a garantir que o trabalho de uma equipe terceirizada atenda aos objetivos do cliente.

Diretriz 6: as informações do projeto devem ser organizadas e um banco de dados deve ser elaborado de maneira a atender aos requisitos da gestão do conhecimento. A falta de organização dos dados do projeto e alta rotatividade de colaboradores geram perda de informações relevantes que poderiam ser utilizadas, por exemplo, como lições aprendidas dentro da organização.

Diretriz 7: ao longo da elaboração de um projeto, muitas situações de risco podem ser identificadas e uma efetiva análise e gestão de riscos podem garantir resultados favoráveis, além de evitar impactos negativos, que geram prejuízos em projetos. 


\section{CONSIDERAÇÕES FINAIS}

\subsection{CONSIDERAÇÕES ACERCA DOS RESULTADOS DA PESQUISA}

A apresentação dos principais conceitos encontrados na bibliografia e sua confrontação com as práticas de gestão de projetos, diante de estudos de caso relativos a projetos industriais, permitiram a formulação de algumas diretrizes básicas para a atuação nesse segmento.

Apesar de os resultados obtidos terem caráter qualitativo e restrito, dado o pequeno número de casos estudados, considera-se que os objetivos da pesquisa foram, portanto, atingidos.

\subsection{CONSIDERAÇÕES SOBRE O TEMA}

A revisão da literatura apresentou os conceitos, ferramentas e diretrizes do processo de projeto, além de evidenciar a importância da gestão para se alcançar o sucesso e atender aos objetivos de determinado projeto. Entretanto, foi observado na prática, desvios e quebras de procedimentos, em alguns casos, e falta de uma gestão mais efetiva em várias situações; especialmente, com enfoque preventivo.

Uma questão de difícil equacionamento para a gestão de projetos no segmento estudado consiste em como controlar o "risco-cliente"; em boa parte das dificuldades e insucessos relatados, o cliente estava na origem do processo, revelando-se um fator de risco que não teve adequado tratamento por parte dos gestores.

Estudos voltados à coordenação de projetos têm mostrado cada vez mais que a atuação do coordenador de projetos é fundamental para garantir que as melhores soluções técnicas e gerenciais sejam alcançadas, atendendo sempre as necessidades e objetivos dos clientes.

No entanto, a maioria dos desvios no processo de projeto identificados nos projetos industriais estudados possui a participação da coordenação de projetos como a responsável pelo resultado obtido. Dificuldades e falhas da coordenação, comuns aos casos analisados, significaram prejuízos quanto ao prazo, custo e qualidade comprometendo o sucesso do projeto.

Esses profissionais que oferecem suporte a elaboração do projeto, integrando a equipe e garantindo a eficiência de todo o processo de projeto até seu encerramento, tendem a ser 
engenheiros que não optaram por seguir a carreira de coordenador, sendo esta uma evolução da própria carreira ou simplesmente uma oportunidade oferecida pela empresa. No Brasil, não é necessário formação específica ou mesmo certificações para exercer a função de coordenador, ou seja, qualquer profissional pode exercer o papel de coordenador de projetos.

Mesmo sendo uma carreira recente, os coordenadores de projetos têm recebido uma valorização tanto pelas empresas como clientes, principalmente quando demonstram ter competência para exercer tal função. Porém, considerando os equívocos que ainda são gerados devido a falhas de gestão, seria o caso de estabelecer quesitos mínimos para o perfil do coordenador de um projeto?

O oferecimento de cursos específicos para a coordenação de projetos especializados no segmento de projetos industriais pode ser uma opção para que estes profissionais tenham competência para garantir soluções eficientes, alcançando o sucesso dos projetos.

\subsection{SUGESTÕES PARA FUTURAS PESQUISAS RELACIONADAS}

O presente trabalho poderá ser a base para novas pesquisas que venham a tratar o mesmo tema.

Como exemplos, sugerem-se algumas possibilidades:

- Pesquisas quantitativas para caracterização da frequência, extensão e impactos da ocorrência de riscos em projetos industriais;

- Desenvolvimento de estudos comparativos das práticas de gestão de projetos industriais envolvendo a realidade de outros países, nos quais há presença de fatores como normas, legislações e códigos de prática profissional capazes de influenciar os resultados;

- Avaliação mais específica e detalhada da utilização da modelagem da informação da construção (BIM) em projetos industriais, seus ganhos e dificuldades;

- Caracterização do perfil, das responsabilidades e das atribuições dos profissionais de gestão, atuantes em diversos e posições, no segmento de projetos industriais, com vistas a contribuir para iniciativas voltadas à educação continuada desses profissionais. 


\section{REFERÊNCIAS BIBLIOGRÁFICAS}

ABAURRE, M.W. Modelos de contrato colaborativo e projeto integrado para modelagem da informação da construção. Dissertação, Escola Politécnica da Universidade de São Paulo, São Paulo, 2013.

ABNT NBR ISO 9001:2008. Sistemas de gestão da qualidade - requisitos. Associação Brasileira de Normas Técnicas, 2008.

ADESSE, E. A liderança do coordenador no processo de projeto. Workshop Brasileiro de Gestão do Processo de Projeto na Construção de Edifícios (IV WBGPPCE), 2004.

ADESSE, E.; SALGADO, M.S. Importância do coordenador do projeto na gestão da construção: a visão do empreendedor (NUTAU), 2006.

AQUINO, J. P. R.; MELHADO, S. B. Perspectivas da utilização generalizada de projetos para produção na construção de edifícios, São Carlos, 2001.

AQUINO, J.P.R., MELHADO, S.B. The importance of the design for productions in the design process management in building construction. Gramado, 2002.

ARANDA-MENA, G, et al. Building information modelling demystified: does it make business sense to adopt BIM?.International Journal of Managing Projects in Business, Bingley, Vol. 2 Iss: 3, pp.419 - 434, 2009.

BALLEJOS, L.C.; MONTAGNA, J.M., Modeling stakeholders for information systems design processes, London, 2010.

BARBER, E.; WARN, J. Leadership in project management: from firefighter to firelighter. Management Decision, Bingley, v. 43, n. 7/8, p.1032-1039, 2005.

BAZJANAC, V. Virtual building environments (VBE) - Applying information modeling to buildings. Lawrence Berkeley National Laboratory, 2004. Disponível em: http://repositories.cdlib.org/lbnl/LBNL-56072. Acesso em: 06 dez. 2011. 
BENNIS, W.; NANUS, B. Leaders: the strategies for taking charge...Harper and Row, New York, 1985.

BERTEZINI, A.L. Métodos de avaliação do processo de projeto de arquitetura na construção de edifícios sob a ótica da gestão da qualidade - Dissertação, Escola Politécnica da Universidade de São Paulo, São Paulo, 2006.

BIRNBERG, H. G. Project management for building designers and owners, CRC Press, 1998.

BOUER, R.; CARVALHO, M.M. Metodologia singular de gestão de projetos: condição suficiente para a maturidade em gestão de projetos? Revista Produção, v.15 n.3 p.347-361, 2005.

BS 6079 3:2000. British Standard Institute. Part 3: Guide to the management of business related project risk, Inglaterra, 2000.

CARVALHO, M.M.; RABECHINI, R.J., Construindo Competências para Gerenciar Projetos, São Paulo, 2005.

CLARKE, P.A., Leadership, beyond project management, Industrial and Commercial Training, Bingley, vol.41 no. 4 2009, p. 187-194, 2009.

COELHO, M.C.P. Metodologia de gestão de projetos de edificações baseadas no PMBok do

CSEPCSÉNYI, A.C.; SALGADO, M.S.; RIBEIRO, R.T.M. Análise do processo de projetos de restauração sob a ótica da gestão da qualidade. XI Encontro Nacional de Tecnologia no Ambiente Construído - ENTAC, Florianópolis, 2006.

DAVENPORT, T. H. Ecologia da informação: porque só a tecnologia não basta para o sucesso na era da informação, São Paulo, 1998.

EL-REEDY, M. Construction management for industrial projects. Wiley-Scrivener, 1st edition, 2012.

EMMITT, S. Design management for architects. Oxford: Blackwell Publishing, 2007. 
FABRICIO, M. M.; MELHADO, S. B. Desafios para a integração do processo de projeto na construção de edifícios, São Carlos, 2001.

FABRICIO, M.M; MELHADO, S.B.; GRILO, L.M. O ensino de projeto e a prática projetual em equipes multidisciplinares. Disponível em http://leonardogrilo.pcc.usp.br/Pesquisas_realizadas.htm, acessado em 21 de maio de 2012.

FAGUNDES, J. L., et al. A gestão da informação no contexto de gerenciamento de projetos, Tecnologia da Informação e Comunicação da Construção Civil - TIC, São Paulo, 2005.

FALSARELLA, O. M.; MONTEIRO, N. A. Um modelo de gestão da informação para aprendizagem organizacional em projetos empresariais. Perspectivas em Ciência da Informação, Brasília, 2007.

FONTENELLE, E.C. Estudos de caso sobre a gestão do projeto em empresas de incorporação e construção, São Paulo, 2002.

GRILO, L.M. Gestão do processo de projeto no segmento de construção de edifícios por encomenda, Escola Politécnica da Universidade de São Paulo, São Paulo, 2002.

GRILO, L.M.; MELHADO, S.B. Novas formas de contratação e organização dos empreendimentos no segmento de construção de edifícios para terceiros. Encontro Nacional de Tecnologia do Ambiente Construído. IX ENTAC, Foz do Iguaçu, 2002.

HALL, D.; HULLET, D. Universal Risk Project, PMI, 2002.

HAO, Q.; KASPER, H.; MUEHLBACHER,J. How does organizational structure influence performance through learning and innovation in Austria and China. Chinese Management Studies, Bingley, vol. 6, no.1, p.36-52, 2012.

HAN, S., et al. A system dynamics model for assessing the impacts of desing errors in construction projects. Mathematical and Computer Modelling, 2013.

ITO, A.L.Y. Gestão da informação no processo de projeto de arquitetura: estudo de caso, Universidade Federal do Paraná, Curitiba, 2007. 
JENSE, P.A.; Jóhannesson, E.I. Building information modelling in Denmark and Iceland. Engineering, Construction and Architectural Management, Bingley, vol.20, no.1, p. 99-110, 2013.

JUGDEV, K., et al. An exploratory study of project success with tools, software and methods. International Journal of Managing Projects in Business, Bingley, vol.6, n.6, p. 534-551, 2013.

KARLSEN, J.T. Project owner involvement for information and knowledge sharing in uncertainty management. International Journal of Managing Projects in Business, Bingley, vol.3, n. 4, p. 642-660, 2010.

KERZNER, H. Gestão de projetos - As melhores práticas - 2a edição, São Paulo, 2004.

KERZNER, H. Project Management - A Systems Approach to Planning, Scheduling, and Controlling. New Jersey: John Wiley \& Sons, 2009.

KHOSROWSHAHI, F.; ARAYICI, Y. Roadmap for implementation of BIM in the UK construction industry. Engineering, Construction and Architectural Management, Bingley, vol. 19, n. 6, p.610-635, 2012.

MANZIONE, L. Proposição de uma estrutura conceitual de gestão do processo de projeto colaborativo com o uso do BIM, Tese, Escola Politécnica da Universidade de São Paulo, São Paulo, 2013.

MARTÍNEZ-LEÓN, I.M.; MARTÍNEZ-GARCÍA, J.A. The influence of organizational structure on organizational learning. International Journal of Manpower, Bingley, vol.32, n. 5/6, p. 537-566, 2011.

MATHEWS, M. BIM collaboration in student archtectural technologist learning. Journal of Engineering, Design and Technology, Bingley, vol.11, n. 2, p. 190-206, 2013.

MCGEE, J.; PRUSAK, L., Gerenciamento estratégico da informação: aumente a competitividade e a eficiência de sua empresa utilizando a informação como uma ferramenta estratégica, Rio de Janeiro, 1994. 
MEDEIROS, M.C.I. Gestão do conhecimento aplicada ao processo de projeto na construção civil: estudo de caso em construtoras - Dissertação, Escola Politécnica da Universidade de São Paulo, São Paulo, 2012.

MELHADO, S.B. Qualidade do projeto na construção de edifícios: aplicação ao caso das empresas de incorporação e construção - Tese, Escola Politécnica da Universidade de São Paulo, São Paulo, 1994.

MELHADO, S.B. Escopo de serviços para coordenação de projetos, Workshop Brasileiro de Gestão do Processo de Projeto na Construção de Edifícios, IV WBGPOPCE, Rio de Janeiro, 2004.

MELHADO, S. B., et al. Coordenação de projetos de edificações, São Paulo, 2005.

MELHADO, S. B., et al. A gestão de projetos de edificações e o escopo de serviços para coordenação de projetos, São Paulo, 2006.

MIGUEL, P.A.C. Estudo de caso na engenharia de produção: estruturação e recomendações para sua condução, Revista Produção, v. 17, nº 1, 2007.

MODARRES, M. Risk analysis in engineering: techniques, tools and trends, Taylor \& Francis Group, 2006.

MULCAHY, R. Risk management: tricks of the trade for project managers, RMC project management, USA, 2003.

NAVARRO, S.S. Planejamento de empreendimentos imobiliários: gestão de risco orientada a gestão de prazo com ênfase na identificação de alertas antecipados, Dissertação, Escola Politécnica da Universidade de São Paulo, São Paulo, 2007.

NÓBREGA Júnior, C.L. Coordenador de projetos de edificações: estudo e proposta para perfil, atividades e autonomia - Tese, Escola Politécnica da Universidade de São Paulo, São Paulo, 2012. 
OLIVEIRA, O.J. Modelo de gestão para pequenas empresas de projetos de edifícios - Tese, Escola Politécnica da Universidade de São Paulo, São Paulo, 2005.

OLIVEIRA, O.J.; FABRÍCIO, M.M.; MELHADO, S.B. Improvement of the design process in the building construction - CIB World Building Congress, Canada, 2004.

ONHUMA, D.K. Modelo de processo para a gestão de subempreiteiros: estudo de caso em empresas construtoras de edifícios - Dissertação, Escola Politécnica da Universidade de São Paulo, São Paulo, 2003.

OTTER, A.D.; EMMITT, S. Exploring effectiveness of team communication: balancing synchronous and asynchronous communication in design teams, Engineering, Construction and Architectural Management, Bingley, vol. 14, n. 5, p. 408-419, 2007.

OTTER, A.D.; EMMITT, S. Design team communication and design task complexity: the preference for dialogues, Architetual Engineering and Design Management, 2008.

PATAH, L.A.; CARVALHO, M.M. Estruturas de gerenciamento de projetos e competências em equipes de projetos - XXII Econtro Nacional de Engenharia de Produção, Curitiba, 2002.

PERMINOVA, O. Managing uncertainty in projects, Abo Akademi University Press, 2011.

PROJECT MANAGEMENT INSTITUTE, PMBOK: Um guia do conhecimento em gerenciamento de projetos, $3^{\text {a }}$ edição, 2004.

PROJECT MANAGEMENT INSTITUTE, PMBOK: Um guia do conhecimento em gerenciamento de projetos, $4^{\mathrm{a}}$ edição, 2008.

PROJECT MANAGEMENT INSTITUTE, PMBOK: Um guia do conhecimento em gerenciamento de projetos, $5^{\mathrm{a}}$ edição, 2010.

PROJECT MANAGEMENT INSTITUTE, Practice standard for project risk management, Newtown Square, 2009. 
QUINTÃO, F. B. M. A gestão de pessoas e a gestão do conhecimento adquirindo papel fundamental no processo de gestão de projetos, III Workshop Brasileiro de Gestão do Processo de Projeto na Construção de Edifícios, Belo Horizonte, 2003.

RABECHINI Junior, R. et al. A organização da atividade de gerenciamento de projetos: os nexos com competências e estrutura, São Carlos, 2011.

RABECHINI Junior, R,; CARVALHO, M.M. Relacionamento entre gerenciamento de risco e sucesso de projetos, Produção, v.23, n.3, 2013.

RABECHINI Junior, R,; CARVALHO, M.M.; LAURINDO, F.J.B. Fatores críticos para implementação de gerenciamento por projetos: o caso de uma organização de pesquisa, Revista Produção V.12 N.2, 2002.

RAMSING, L. Project communication in a strategic internal perspective, Journal of Corporate Communications, Bingley, vol.14, n. 3, p. 345-357, 2009.

RICARDINO, R.; SILVA, S.A.R.; ALENCAR, C.T. Administração de Contrato em projetos de construção pesada no Brasil: um estudo da interface com o processo de análise do risco. Boletim Técnico da Escola Politécnica da USP, São Paulo, 2008.

ROVAI, R.L. Modelo estruturado para gestão de riscos em projetos: estudo de múltiplos casos, Tese de doutorado - Escola Politécnica da Universidade de São Paulo, São Paulo, 2005.

SANTIAGO Junior, J. R. S. Gestão do conhecimento: a chave para o sucesso empresarial, Editora Novatec, São Paulo, 2004.

SCHUYLER, J. Risk and decision analysis in projects, Project Management Institute, 2001.

SILVA, G.V. Gestão do Processo de Projeto - Estudo de caso em pequenos escritórios de arquitetura de Florianópolis - SC, Universidade Federal de Santa Catarina, Florianópolis, 2011. 
SILVA, S.A.R. Programações por recurso: o desenvolvimento de um método de nivelamento e alocação com números nebulosos para o setor da construção civil - Tese, Escola Politécnica da Universidade de São Paulo, São Paulo, 1999.

SILVA, M.V.F.P; NOVAES, C.C. A coordenação de projetos de edificações: estudos de caso, Gestão \& Tecnologia de Projetos, 2008.

SKULMOSKY, G.J.; HARTMAN, F.T. Information systems project manager soft competencies: A project-phase investigation, Project Management Journal, Wiley Interscience, 2010.

SOUZA, A.L.R. Preparação e execução da coordenação de obras: transposição da experiência francesa para a construção brasileira de edifícios. Tese de doutorado - Escola Politécnica da Universidade de São Paulo, São Paulo, 2001.

TERRA, J.C.C. Gestão do Conhecimento: o grande desafio empresarial, 5a edição, Negócio Editora, 2005.

TERRA, J.C.C. Reflexões sobre a evolução da Gestão do Conhecimento no Brasil, Produto \& Produção, vol. 8, nº $^{\circ}, 2005$.

THUYET, N.V.; OGUNLANA, S.O.; DEY, P.K. Risk management in oil and gas construction projects in Vietnam, International Journal of Energy Sector Management, Bingley, vol. 1, n. 2, p.175-194, 2007.

UNDERWOOD, J.; ISIKDAG, U. Emerging Technologies for BIM 2.0, Construction Innovation, Bingley, vol.11, n. 3, p. 252-258, 2011.

VALLE, A.B. et al. Fundamentos do gerenciamento de projetos, Editora FGV, Rio de Janeiro, 2007.

VASCONCELLOS, E.; HEMSLEY, J. R. Estruturas das organizações: Estruturas Tradicionais, Estruturas para Inovação, Estrutura Matricial. 4. ed. São Paulo: Editora Thomson Pioneira, 2002. 
VIVANCOS, A.G.; CARDOSO, F.F. Estruturas organizacionais de empresas construtoras de edifícios, Escola Politécnica da Universidade de São Paulo, São Paulo, 2001.

YIN, R.K. Estudo de caso - planejamento e métodos, Bookman, 2001.

WIDEMAN, R.M. Project and program risk management: a guide to managing project risks and opportunities, Project Management Institute, 1992.

WONG, K.; Fan, Q. Building information modelling (BIM) for sustainable building design, Facilities, Bingley, vol. 31, n. 3/4, p. 138-157, 2013. 


\section{APÊNDICE A - ROTEIRO DE ESTUDO DE CASO}

1) Nome da empresa:

2) Responsável pelas informações:

a. Email:

b. Telefone:

3) Ramo / Segmento:

4) Número de funcionários:

5) Faturamento médio anual:

6) Tempo de atuação no mercado:

7) Estrutura Organizacional:

\begin{tabular}{|l|l|}
\hline & Funcional \\
\hline & Matricial \\
\hline & Projetizada \\
\hline
\end{tabular}

Obs. sobre a Estrutura Organizacional:

8) Quantidade de projetos ativos:

9) Quantidade de gerentes de projetos:

10) Há divisão na gestão entre Coordenador Técnico e Gerente de Projeto? Se sim, quantos são?

11) Tempo médio de duração dos projetos:

12) Atende mercado nacional?

13) Atende mercado internacional?

14) Conhecem as práticas de gestão de projetos - PMBoK?

15) Aplicam as práticas de gestão de projetos - PMBoK? 
16) Como são gerenciadas as fases (ciclo de vida dos projetos)? Indicar ordem:

\begin{tabular}{|l|l|}
\hline Ordem & Fase \\
\hline & \\
\hline & \\
\hline & \\
\hline & \\
\hline & \\
\hline & \\
\hline & \\
\hline & \\
\hline & \\
\hline
\end{tabular}

17) Para cada fase, quais são os processos que se utiliza na gestão:

\begin{tabular}{|l|l|}
\hline Ordem & Processo \\
\hline & \\
\hline & \\
\hline & \\
\hline & \\
\hline & \\
\hline & \\
\hline & \\
\hline & \\
\hline & \\
\hline & \\
\hline
\end{tabular}

18) Para cada fase, quais documentos são utilizados:

\begin{tabular}{|l|l|}
\hline Ordem & Documento \\
\hline & \\
\hline & \\
\hline & \\
\hline & \\
\hline & \\
\hline & \\
\hline & \\
\hline & \\
\hline & \\
\hline & \\
\hline & \\
\hline
\end{tabular}


19) Os processos são padronizados/automatizados pelo uso de algum software ou sistema de intranet? Se sim, qual(is)? Explicar.

20) A equipe envolvida em cada empreendimento / projeto é exclusiva ou compartilhada?

21) A empresa possui algum sistema de gestão que tenha influência direta com o processo de projeto? (gestão da qualidade / de projetos / do conhecimento)? Em caso de certificação nas normas ISO, qual tipo e escopo da certificação? Quem é o responsável pelos sistemas?

22) Que conhecimento necessita ser gerenciado (informação, conhecimento pessoal)?

23) Quais ferramentas / instrumentos de Gestão do Conhecimento a empresa utiliza para captura, armazenamento e compartilhamento de conhecimento?

\begin{tabular}{|l|l|}
\hline & $\begin{array}{l}\text { Focadas em TI: Sistemas de banco de dados, sistemas de gerenciamento } \\
\text { de documentos, fóruns eletrônicos de discussão. }\end{array}$ \\
\hline $\begin{array}{l}\text { Focado nas pessoas / organização: seminários, treinamentos, } \\
\text { brainstorming, registro de liçôes aprendidas, mapeamento de } \\
\text { competências e habilidades. }\end{array}$ \\
\hline
\end{tabular}

24) Há uma padronização de projeto da empresa a ser seguida pelos projetistas? Existe um manual?

25) Existe um fluxo básico de desenvolvimento de projetos? Ele é padronizado ou desdobrado de acordo com a tipologia de cada empreendimento?

26) Como é estabelecido o planejamento das atividades de projetos (definição das atividades, sequenciamento, estimativas de duração)? Quem estabelece os prazos de entrega dos projetos? A equipe de produção é envolvida?

27) Há controle de recebimento, análise crítica e verificação/validação dos projetos? Quem é o responsável pela validação / aceitação dos projetos?

28) Quais as principais dificuldades encontradas na coordenação de projetos (datas previstas são cumpridas / integração entre os projetistas)?

29) Quais são as principais fontes de mudança dos projetos (clientes, problemas de projetos, não atendem às normas, alteração de premissas)? Em que fase as mudanças ocorrem com maior frequência? É feita alguma avaliação sobre os impactos das mudanças quanto a custo, tempo, desempenho, qualidade? Quais os profissionais 
envolvidos nessa avaliação? Como são aprovadas as mudanças e quem é o responsável?

30) Os projetos têm atendido as expectativas dos clientes? Existe alguma pesquisa de satisfação enviada ao cliente?

31) Estudo de Caso - Descrição Geral
a. (\$)
b. $\left(\mathrm{M}^{2}\right)$
c. Prazo
d. Segmento

32) Modelo Contratual do Projeto em Questão

\begin{tabular}{|l|l|}
\hline & Avanço Físico \\
\hline & Marcos Contratuais - Eventos \\
\hline & Administração - HH \\
\hline & \\
\hline & \\
\hline & \\
\hline
\end{tabular}

33) Principais Agentes Envolvidos

\begin{tabular}{|l|l|}
\hline & Cliente \\
\hline & Gerenciadora \\
\hline & Equipe de Projeto (Disciplinas? Organograma?) \\
\hline & Terceirizados \\
\hline & Outros (especificar) \\
\hline & \\
\hline
\end{tabular}

34) Qual equipe do empreendimento em questão? Compartilhada? Grupo Tarefa?

35) Reuniões: tipo e frequência

\begin{tabular}{|l|l|}
\hline Frequência & Tipo \\
\hline & Kick Off Meeting interna \\
\hline & Kick Off Meeting com cliente \\
\hline & Reunião Técnica \\
\hline & Reunião Interna de Coordenação \\
\hline & Reunião Gerencial com Cliente \\
\hline & \\
\hline & \\
\hline
\end{tabular}


36) De que forma são registradas e controladas as informações?

\begin{tabular}{|l|l|}
\hline & Ata de Reunião \\
\hline & Lista de Pendências \\
\hline & Lista de Premissas \\
\hline & Emails \\
\hline & \\
\hline & \\
\hline
\end{tabular}

37) Informações de referência enviadas pelo cliente (forma de envio, qualidade, análise):

38) Perfil dos gestores (para o entrevistado, omitir as opções)

\begin{tabular}{|l|l|}
\hline & Formação (Engenheiro?) / Pós-graduação? \\
\hline & Tempo de experiência na função? \\
\hline & Qual autonomia no projeto? A quem está subordinado? \\
\hline & Quais são as suas atribuições e responsabilidades? \\
\hline & Outros idiomas? Quais? \\
\hline & Flexível? \\
\hline & Proativo? \\
\hline & Comunicativo? \\
\hline & Acessível? \\
\hline & Autocontrole? \\
\hline & Facilitador de soluções? \\
\hline & Motiva equipe? \\
\hline
\end{tabular}

39) Histórico do Caso

\begin{tabular}{|l|l|}
\hline Data & Ocorrência \\
\hline & \\
\hline & \\
\hline & \\
\hline & \\
\hline & \\
\hline & \\
\hline & \\
\hline
\end{tabular}

40) Particularidades, dificuldades e riscos do caso. 